\title{
Offender Desistance: An Examination of Creating Choices as it is Applied in Community Corrections
}

\author{
A thesis submitted to \\ the Faculty of Graduate Studies and Research \\ in Partial Fulfillment of the requirements for the degree
}

Master of Arts

By

Shannon Gottschall

Department of Psychology

Carleton University

September 2008

(C) 2008 Shannon Gottschall 


$\begin{array}{ll}\begin{array}{l}\text { Library and } \\ \text { Archives Canada }\end{array} & \begin{array}{l}\text { Bibliothèque et } \\ \text { Archives Canada }\end{array} \\ \begin{array}{l}\text { Published Heritage } \\ \text { Branch }\end{array} & \begin{array}{l}\text { Direction du } \\ \text { Patrimoine de l'édition }\end{array} \\ \begin{array}{l}\text { 395 Wellington Street } \\ \text { Ottawa ON K1A 0N4 } \\ \text { Canada }\end{array} & \begin{array}{l}\text { O95, rue Wellington } \\ \text { Ottawa ON K1A 0N4 } \\ \text { Canada }\end{array}\end{array}$

Your file Votre référence ISBN: 978-0-494-43459-8

Our file Notre référence

ISBN: 978-0-494-43459-8

NOTICE:

The author has granted a nonexclusive license allowing Library and Archives Canada to reproduce, publish, archive, preserve, conserve, communicate to the public by telecommunication or on the Internet, loan, distribute and sell theses worldwide, for commercial or noncommercial purposes, in microform, paper, electronic and/or any other formats.

The author retains copyright ownership and moral rights in this thesis. Neither the thesis nor substantial extracts from it may be printed or otherwise reproduced without the author's permission.
AVIS:

L'auteur a accordé une licence non exclusive permettant à la Bibliothèque et Archives Canada de reproduire, publier, archiver, sauvegarder, conserver, transmettre au public par télécommunication ou par l'Internet, prêter, distribuer et vendre des thèses partout dans le monde, à des fins commerciales ou autres, sur support microforme, papier, électronique et/ou autres formats.

L'auteur conserve la propriété du droit d'auteur et des droits moraux qui protège cette thèse. $\mathrm{Ni}$ la thèse ni des extraits substantiels de celle-ci ne doivent être imprimés ou autrement reproduits sans son autorisation.
In compliance with the Canadian

Privacy Act some supporting forms may have been removed from this thesis.

While these forms may be included in the document page count, their removal does not represent any loss of content from the thesis.
Conformément à la loi canadienne sur la protection de la vie privée, quelques formulaires secondaires ont été enlevés de cette thèse.

Bien que ces formulaires aient inclus dans la pagination, il n'y aura aucun contenu manquant.

\section{Canada}




\begin{abstract}
A sample of 36 parolees ( 27 males, 9 females) and 10 parole officers ( 4 males, 6 females) from six parole offices across Canada completed questionnaires assessing the quality of their relationship. The measures were used to examine adherence to the principles of Creating Choices, the philosophy behind federal women offender correctional policies. No gender differences were observed in adherence, despite the policy's link to women offender corrections; responses generally indicated a high degree of adherence. Parole officer and parolee responses showed high agreement. No significant associations were found between parolee outcomes (i.e., indications of failure as recorded by parole officers in casework records) and the measures. The results are discussed in relation to the limitations of the study. Future directions discussed centre on the strengths of this study in its attention to an underdeveloped area of research and promising psychometric analyses for a new measure, the Creating Choices Principles Questionnaire.
\end{abstract}




\section{Acknowledgements}

This project would not have been possible without the collaboration and support of a number of individuals. First and foremost, I must thank my supervisor, Dr. Ralph Serin, for his guidance and support. I must also thank my committee members, Drs. Shelley Brown, Craig Bennell, and Diana Majury, for their insightful feedback and interest in my research.

The support of the Women Offender Sector, Community Reintegration Operations, and Research Branch at the Correctional Service of Canada was also critical to the completion of this project. I am especially grateful to Kelley Blanchette and Renée Gobeil at the Research Branch, and Bev Arseneault at Community Reintegration Operations. I must also thank the parole officers and parolees who took the time to participate in my study and contribute to this research.

I feel very fortunate to have benefitted from the support and friendship of fellow members of Dr. Serin's lab over the past two years. Special thanks to Caleb Lloyd and Renée Gobeil for their encouragement and practical advice. I must also thank Etelle Bourassa and Payal Chadha at the Psychology Department for their guidance and support in administrative matters.

I was also fortunate enough to receive financial support over the last two years from the Social Sciences and Humanities Research Council and Ontario Graduate Scholarship Program, without which this research would not have been possible.

Finally, I am very grateful to my family for their love and support. 
Table of Contents

$\begin{array}{ll}\text { Abstract } & \text { ii }\end{array}$

Acknowledgements

Table of Contents $\quad$ iv

List of Tables vi

List of Appendices vii

Introduction 1

The Principles of Creating Choices 3

Research Support for the Principles $\quad 5$

Empowerment

$\begin{array}{ll}\text { Meaningful and Responsible Choices } & 11\end{array}$

Respect, Dignity, and a Supportive Environment 16

$\begin{array}{ll}\text { Shared Responsibility } & 29\end{array}$

$\begin{array}{ll}\text { Current Study } & 32\end{array}$

$\begin{array}{ll}\text { Hypotheses } & 34\end{array}$

Method 35

$\begin{array}{ll}\text { Participants } & 35\end{array}$

$\begin{array}{ll}\text { Measures } & 36\end{array}$

Dual Role Relationship Inventory --Revised (DRI-R) 36

Parole Officer Punishment and Reintegrative Orientation 37

Questionnaire (POP-ROQ)

Creating Choices Principles Questionnaire (CCPQ) 38

Rosenberg Self-Esteem Scale (RSE) 39 
Dependent Variable $\quad 42$

$\begin{array}{ll}\text { Procedures } & 42\end{array}$

Data Cleaning and Analyses $\quad 43$

Data Cleaning $\quad 43$

$\begin{array}{lr}\text { Psychometric Analyses } & 45\end{array}$

Adherence to Creating Choices $\quad 45$

$\begin{array}{ll}\text { Assessing Covariates } & 45\end{array}$

Associations with Outcome and Gender Differences $\quad 46$

$\begin{array}{ll}\text { Results } & 47\end{array}$

$\begin{array}{ll}\text { Psychometric Analyses } & 47\end{array}$

Adherence to Creating Choices 51

$\begin{array}{ll}\text { Assessing Covariates } & 51\end{array}$

Associations with Outcome and Gender Differences 54

$\begin{array}{ll}\text { Discussion } & 61\end{array}$

Adherence to Creating Choices $\quad 61$

$\begin{array}{ll}\text { Assessing Covariates } & 65\end{array}$

Associations with Outcome and Gender Differences 66

$\begin{array}{ll}\text { Study Limitations } & 69\end{array}$

$\begin{array}{ll}\text { Strengths and Conclusions } & 72\end{array}$

$\begin{array}{ll}\text { References } & 75\end{array}$

$\begin{array}{ll}\text { Appendices } & 87\end{array}$ 
List of Tables

Table 1. Chi-square tests of independence between dichotomous parolee outcome and categorical covariates.

Table 2. Correlations between scale and subscale totals and dichotomous outcome for male and female parolees.

Table 3. Point-biserial correlations between subscale totals and dichotomous outcome for male and female parolees.

Table 4. Correlations between parole officer subscale totals (separated by 58 interactions with male and female parolees) and parole officer outcomes.

Table 5. Results of receiver operating characteristic (ROC) curve analyses for scales and subscales in predicting parolee dichotomous outcomes. 
List of Appendices

Appendix A: List of Items from Subscales of Modified Dual Role Relationship Inventory - Revised (DRI-R)

Appendix B: List of Items from Modified Parole Officer Punishment and

Reintegrative Orientation Questionnaire (POP-ROQ)

Appendix C: Creating Choices Principles Questionnaire (CCPQ) Items

Appendix D: Rosenberg Self-Esteem Scale (RSE)

Appendix E: Modified Drinking Motives Questionnaire (DMQ) 106

Appendix F: Covariate Questionnaires

Appendix G: Informed Consent for Parole Officers and Parolees

Appendix H: Parolee/Parole Officer Debriefing

Appendix I: DRI-R Psychometrics

Appendix J: POP-ROQ Psychometrics

Appendix K: CCPQ Psychometrics

Appendix L: RSE Psychometrics

Appendix M: DMQ Subscale Psychometrics 


\section{Offender Desistance:}

An Examination of Creating Choices as it is Applied in Community Corrections

Although the tendency of offenders to cease and desist offending at some point in their lives is a widely-publicized and recognized phenomenon, it is one of the most under-studied in criminology and related fields (Sommers, Baskin \& Fagan, 1994). Concerns over public safety and the management of offender risk are still popular topics of discussion among academics and professionals in the area of corrections, but recent decades have shown great development in research on offender desistance and success in the community. It has been suggested that research on processes and correlates related to desistance may inform and improve programs and services offered to offenders (Farrall \& Maruna, 2004). It is possible that the women offender population in particular may benefit from such research and the policies informed by such research; the characteristically low risk presented by the group may make focusing on women's strengths advantageous and is, indeed, in keeping with the principles outlined in the seminal document, Creating Choices: Report of the Task Force on Federally Sentenced Women (Task Force on Federally Sentenced Women, 1990). This document has essentially formed the basis of women offender policies in federal corrections in Canada since its release.

Community corrections was one of the key priorities outlined in Creating Choices; one of the five principles of the report focused on forming partnerships with resources and groups in the community to ensure continuity of care and support for women as they re-enter the community. Since the release of Creating Choices and the implementation of its recommendations, several reports have indicated that its 
implementation in community corrections in particular has been somewhat less than satisfactory. A ten-year status report from 1996 to 2006, showed that some advancements had been made (e.g., in the expansion of community residential services for women offenders), but there were also reports of problems with human resource needs (e.g., that some community parole officers had not received women-centred training), and one of the report's recommendations was that the Correctional Service of Canada (CSC) assign greater priority to women's corrections in the community (Expert Committee, 2006). The Office of the Correctional Investigator (2006) showed concern over the finding that in recent years women offenders have been increasingly likely to be released at their statutory release date rather than earlier on parole. They also recommended more women-centred training for staff and parole officers. Further, a research report from CSC indicated that the proportion of women admitted to federal institutions for revocations from community supervision increased from 5\% in 1991 to $17 \%$ in 2002 (Sinclair \& Boe, 2002).

Together these findings appear to demonstrate recent failures in getting women offenders on parole and keeping them in the community when on parole, which are surprising given the low risk posed by women offenders, underscoring the human resource problems cited. Thus, it is of interest to ascertain whether there has been a problem with the implementation of the principles of Creating Choices in community corrections for women, or if there appears to be a problem with the principles themselves as they relate to women's lack of success in the community. The current study attempted to address these questions, but before discussing the results of this study a further explanation will be given of the specific principles of Creating Choices and the support 
for these principles in the extant literature, particularly as they relate to community corrections for women offenders.

\section{The Principles of Creating Choices}

Five principles were recommended to be the foundation of women's corrections. The first principle was empowerment for women offenders and involved developing women's strengths, and increasing women's self-esteem and internal locus of control or belief that they are in control of their lives. The Task Force suggested that obstacles typically faced by women offenders throughout their lives (e.g., trauma or abuse, poverty and discrimination) has left these women feeling powerless and unable to take advantage of opportunities to improve their lives. The Task Force indicated that their research and consultations revealed the importance of increased self-esteem in the improved outcomes of women. While it has been questioned whether empowerment is possible in a prison environment that is, by nature, restrictive and offering limited choice (Hannah-Moffat, 2000), community corrections offers the flexibility and freedom that may be more conducive to the achievement of such a goal.

The second principle of Creating Choices was closely related to the first and involved creating options for women offenders, so they have the opportunity to make meaningful and responsible choices, which in turn was expected to increase their selfesteem and feelings of empowerment. When consulted, women offenders expressed the desire to have more choices related to diet, exercise and health care. Making choices in the areas of programs and community services, for example, was also seen as providing practice or preparation for making other important decisions in the community. 
Dependence on others (e.g., partners, family or the state) and substance abuse were seen as limiting women's ability to make meaningful and responsible choices.

Treating women offenders with mutual respect and dignity was recommended as the third principle of Creating Choices. This included respecting and accommodating cultural and spiritual needs and beliefs. The principle was based on the observation that offenders were more likely to act responsibly when approached with respect and dignity. Women offenders had articulated to the Task Force that they experienced feelings of humiliation and powerlessness when subjected to seemingly arbitrary rules. This particular application of this principle, then, relates back to the first principle of empowerment, and the second principle of meaningful and responsible choices.

The fourth principle could also be seen as affecting all preceding elements of women offender practice. It involved creating a positive and mutually supportive environment, without which the other principles and goals could not be achieved. This should include the political, physical, financial, emotional/psychological and spiritual aspects of the environment. In the community, in particular, the application of this principle can be measured in the amount of assistance, advice and advocacy provided. The fifth principle of shared responsibility, again, related to the aforementioned principles. The Task Force suggested that partnerships between governments, correctional agencies, and community groups were needed to ensure continuity of care and service, and provide continuity in the provision of empowerment, choices, respect and dignity, and support. This last principle allowed for application of the womencentred philosophy of corrections throughout the women's prison sentence and 
reintegration in the community through supervision, providing more of a seamless transition for women.

Creating Choices also included recommendations related to the structure of services provided in the community (i.e., availability of programs and residences) and the structure of governance of community corrections (i.e., accountability) but these are not outlined here because they are not related to the current study. Assessing the success of the implementation of these recommendations is beyond the scope of this study. As a psychological investigation, the current study will emphasize the interpersonal aspects of the implementation of the above principles, particularly as they apply to the relationship between parole officers and parolees. Given the interrelation among the principles of Creating Choices, it is difficult to separate related research according to the five categories but what follows is an attempt to do so, with a focus on research relating to the aforementioned interpersonal aspects of the principles, wherever possible.

Research Support for the Principles

\section{Empowerment}

Researchers have recognized the feelings of disempowerment experienced by women offenders, beginning in dysfuntional and traumatic childhoods, and building into adulthood (e.g., Wilson \& Anderson, 1997). The association between childhood abuse and low community connections has been found to be non-significant when controlling for empowerment, suggesting empowerment may mediate the relationship between victimization and negative outcomes (Banyard \& LaPlant, 2002). This finding has practical significance for women offender correctional policy given the high rates of victimization among women offenders (e.g., Wilson \& Anderson, 1997). The 
disempowerment of women offenders on the basis of gender stereotypes and discrimination has even been apparent in the commission of their offences. In a study of residential burglaries, Mullins and Wright (2003) found that women often worked in mixed-gender groups, taking on subordinate roles, believing that they were unable or lacked the skills to work alone.

It has been suggested that desistance from crime not only involves discarding one's criminal identity but also developing a new pro-social identity (Farrall \& Maruna, 2004). Maruna, LeBel, Mitchell, and Naples (2004) differentiated between primary and secondary desistance; the former being a mere gap or lull in criminal activity, and the latter involving the assumption of a new pro-social identity/label and the commitment to desist. Given the feelings of powerlessness and dependence experienced by women offenders in particular, it may be that this shift in identity is even more important for their success than it is for male offenders. Through interviews with a small sample of Israeli male and female offenders, Geiger and Fischer (2005) determined that men were better able to resist the stigma of their criminal identity (e.g., by appealing to higher loyalties or taking pride in their skills/strengths). Women offenders found it difficult to deal with the stigma of being a bad mother, given the master status assigned to motherhood in women's identities based on sexist norms. This threat to their identity left them more vulnerable to feelings of powerlessness and low confidence than would be the case for men, simply because of gender norms. Geiger and Fischer suggested that interventions with women offenders should focus on building strengths (e.g., in education, employment, child care), increasing confidence, and empowering women to make decisions that can help them redefine themselves with a more positive identity. 
Practitioners have also recognized the importance of empowering interventions for women offenders. In a survey of thirty-five wardens of women's prisons in the United States, of which many were women themselves, van Wormer and Kaplan (2006) found that several explicitly mentioned the need for women-specific programs in openended questions related to women's needs. The wardens suggested that few women offenders would be considered feminists and may benefit from programs focusing on empowering the women through encouraging them to express themselves.

While many have highlighted the importance of an empowering intervention for women offenders, few have outlined the elements of such an intervention. Wilson and Anderson (1997) described five dimensions of appropriate practice, including the personal, social, political, educational, and economic. The personal domain involves building on individual skills, confidence and motivation, and teaching women to be more proactive and take control of their lives. The case worker, or whoever is involved in the intervention, is seen as a partner with the woman in this process, as well as a mentor and advocate. Social and political empowerment involves bringing women together in the community and mobilizing their involvement in the community and their own selfgovernance. The educational and economic domains entail providing opportunities for growth in the area of education and/or employment and income. Worell (2001) generally described a feminist intervention as involving the building of problem-solving and life skills and providing the means and opportunities for women to pursue changes not just in their individual lives but at a societal level, in order to challenge norms and conditions that disempowered them. Worell suggested five areas of a feminist intervention, including prevention, education, remediation, empowerment and community change. 
The first two areas involve creating awareness about gender norms and discrimination and preventing or reducing the impact of gender socialization. Remediation addresses the distress and harm caused by gender discrimination and subordination, while empowerment and community change involve providing individual women with strategies to deal with challenges in the environment, and adopting strategies to change that environment, respectively.

Worell (2001) also listed ten components of empowerment, including selfevaluation, comfort-distress, gender/culture awareness, personal control, self-nurturance, problem-solving, flexibility, assertiveness, resource access, and social activism. Two of these components have been grouped together in the study of desistance from crime; positive self-evaluation and perceived personal control or internal control in certain situations have been found to relate to positive outcomes for offenders. Using data collected as part of the Liverpool Desistance Study, Maruna (2004) found that offenders who desisted from offending showed an optimistic bias in their explanation of life events, compared to offenders who persisted in criminal activity, when matched on demographic variables including gender. Offenders with positive outcomes were found to explain negative life events as having external causes, being unstable in duration, and specific to one part of their lives. Internal factors were seen to cause positive events, which were perceived as being stable over time, and global and affecting many areas of their lives. Persisting offenders demonstrated the opposite thinking pattern.

Burnett and Maruna (2004) discovered that this sort of optimism and positive evaluation or belief in oneself does not appear to need to be realistic in order for its relationship with positive outcomes to be present. Male offenders with higher hope for 
successful reintegration demonstrated greater success upon release, while controlling common correlates of outcome, including age, criminal history, and social problems in the areas of employment and marriage. Gadd and Farrall (2004) also found positive attitudinal biases in the life narratives of two male offenders who appeared to be in the process of desisting. Past criminal behaviour was blamed on circumstances and the influences of others, while current success was perceived as stemming from free will and their futures were described with hope for their children.

Maruna, Porter and Carvalho (2004) discussed the implications of such findings for work with offenders. They suggested practitioners should focus on building on the strengths and the positive image and self-efficacy of offenders, possibly by “[e]mpowering ex-prisoners to 'earn their way back' in to the mainstream through demonstrations of their 'true' inner character..." (Maruna, Porter \& Carvalho, 2004, 228). Such acts of redemption were seen as sending a positive message to the offender and the community about the true identity and the future of the offender. It has even been suggested that such recognition of an offender's new pro-social identity be institutionalized through the authority of a strengths-based 'reentry court' (Maruna \& LeBel, 2003). The official support and acceptance of an offender's pro-social identity was frequently described by interviewed offenders discussing their progress; progress was marked by certain milestones (e.g., job promotion) and testimonials/praise from those in authority (Maruna et al., 2004). During the interviews, which were part of a program evaluation involving the collection of qualitative data, offenders also discussed finding meaning and purpose to redeem themselves and join the community again. 
Interviews with a small sample of women offenders also showed that 'giving back' to the community was seen as being a marker of success upon release from prison (O'Brien, 2001b). Women described developing community membership by helping the community in some way and being able to contribute as reflecting their citizenship and inclusion in the community. Women also discussed internal changes that indicated success upon release, including higher self-efficacy, possessing greater relational skills or competencies, making positive decisions and developing a sense of hope. In recognition of these developments in desistance research, especially the work of Maruna and colleagues (2004), the popular and empirically-supported risk-need-responsivity (R-N-R) model of effective correctional practice has been adapted to accommodate the development of anticriminal identities as part of dynamic needs in the area of antisocial cognition (Andrews, Bonta, \& Wormith, 2006). The R-N-R model consists of a risk principle stating that treatment intensity should be matched to offender risk, a need principle stating that treatment should target those needs associated with criminal behaviour, and a responsivity principle that suggests treatment style should be tailored to the learning style, personality, and other individual characteristics of the offender (Andrews, 2001). Recently, proponents and indeed even architects of the R-N-R model of effective correctional practice have supported the inclusion of strengths in the model and have encouraged the further development of empirical research in this area (Andrews, Bonta, \& Wormith, 2006; Andrews \& Dowden, 2007).

These developments clearly support the elements of empowerment described by researchers, theorists and the Task Force on Federally Sentenced Women in Creating Choices. Although there appears to be a wealth of philosophical support for the 
empowerment principle, there remains a paucity of empirical research on the association between empowerment and offender outcomes. The current study attempted to address this gap in the empirical correctional literature. Empirical research in other disciplines supports the link between empowerment and positive outcomes in the workplace (Hechanova, Alampay \& Franco, 2006; Koberg, Boss, Senjem, \& Goodman, 1999; Patrick \& Spence Laschinger, 2006; Yoder, Schleicher, \& McDonald, 1998), and in the mental health field (Roth \& Crane-Ross, 2002). As it was described by the Task Force, empowerment can help women to see and seize opportunities to make meaningful and responsible choices, and making meaningful and responsible choices can increase selfefficacy and feelings of empowerment. These choices can relate to areas of women's lives, such as education, employment and substance use or abuse. Research linking these areas to desistance or positive outcomes is discussed in the following section.

\section{Meaningful and Responsible Choices}

More concrete markers of successful reintegration have also been described by women offenders, including finding shelter, obtaining employment, and improving relationships (O'Brien, 2001b). Engagement in employment or school has been one of the most commonly researched correlates of desistance from crime. In a seminal study involving the re-examination of longitudinal data from delinquent and non-delinquent males collected decades earlier, Sampson and Laub (1990) discovered that job stability and marital attachment were linked to the avoidance of further criminal activity among the delinquent boys as they grew into adulthood. While this study involved historical data, more recent research has supported the relationship between employment or school and desistance among male offenders (Stouthamer-Loeber, Wei, Loeber \& Masten, 
2004), and in mixed-gender samples (Kosterman, Hawkins, Abbott, Hill, Herrenkohl \& Catalano, 2005). Haggård, Gumpert and Grann (2001) failed to find a significant relationship between employment or school and desistance in male offenders, but used a very small sample. Using a mixed-gender sample, Giordano, Cernkovich and Rudolph (2002) also found this relationship to be non-significant, but suggested that the racial/ethnic heterogeneity of their sample may have influenced their results. Katz (2000) studied the effect of social capital, including employment, on the outcomes of women offenders, and found a stronger association for Caucasian women.

When research results involving mixed-gender samples were disaggregated by gender, the results appeared mixed. Hser, Huang, Teruya and Anglin (2003) found that, among other variables, employment was related to desistance in males but not in women offenders, although the significance of this difference did not appear to be tested. Uggen and Kruttschnitt (1998) also found an association between employment and self-reported illegal earnings among only male offenders, but this gender difference was not found to be significant, and employment or school was related to self-reported arrest for both genders. It was suggested that the inconsistency in the correlates of the two self-report measures may be accounted for by the differences between correlates of official responses to offenders and the actual criminal activity of offenders. Benda (2005) found that employment was more important to the desistance of male offenders and relationships were more important to the desistance of women offenders, reflecting instrumental and social orientations of the two groups, respectively.

Research on the employment needs of women offenders, relative to male offenders, appears contradictory. Motiuk (1997) failed to find a significant gender 
difference in the employment needs of offenders in federal custody in Canada, as they were assessed upon admission. On the other hand, Krienert and Fleisher (2001) found women offenders to have lower incomes and less stable employment prior to incarceration when interviewing a voluntary sample of federal inmates in the United States. The differing methodologies and sample selections of the two studies may account for the different findings. Alternatively, given that few indicators of employment need considered in the overall assessments of need in Motiuk's (1997) research addressed the incomes and employment stability of Krienert and Fleisher's (2001) work, these findings may be reconciled. Perhaps many of Motiuk's (1997) indicators (e.g., learning difficulty, low initiative) are insufficient to adequately reflect the employment situations of women offenders relative to male offenders. Women's employment situations are complicated by their relationships with children and partners, which can be reflected in their low incomes and employment instability (Krienert \& Fleisher, 2001). Nonetheless, it would appear these employment need assessments are still associated with women offender outcomes (Law, 2004; Verbrugge, Nunes, Johnston \& Taylor, 2002).

Interviews with a small sample of American women offenders in the community revealed that employment was considered a highly-rated factor in their post-prison adjustment (Harm \& Phillips, 2001). McLean, Robarge and Sherman (2006) found a larger sample of incarcerated American women expected employment to be among the top five factors they believed would assist them upon release. Interviews with women offenders in Canada also revealed the women's belief that employment would be related to their success upon release, but indicated that women were unhappy with the employment programs available to them (Delveaux, Blanchette \& Wickett, 2005). 
Among the problems discussed, the women suggested the programs needed to be more 'life-like,' few women were given work releases, and those women with jobs after incarceration did not link them to their participation in prison programs. This is consistent with the findings of O'Brien and Bates (2005), which showed that $40 \%$ of the variability in re-arrest of women offenders one year after release was accounted for by employment in the year before prison, a history of hospitalization related to mental health, participation in prison industries programs, and interactions between hospitalization and both substance abuse programs and employment history. While employment history and participation in prison industries programs were related to rearrest, vocational programs in prison, which did not provide the kind of 'real-life' experience of prison industries programs, were not related to outcome. These studies may be said to highlight the importance of community corrections in meeting the employment needs of women offenders and improving post-release outcomes.

Several of the aforementioned studies in this section also examined the influence of substance abuse, another area of meaningful and responsible choices for women offenders. The O'Brien and Bates (2005) study, just discussed, found participation in substance abuse programs to be related to outcome through an interaction with mental health hospitalization. Research has shown an association between substance abuse and outcome in samples of male offenders (Håggard, Gumpert \& Grann, 2001; Hussong, Curran, Moffitt, Caspi \& Carrig, 2004), and women offenders (Gottschall \& Serin, 2008; Hume, 2004; Verbrugge et al., 2002). Qualitative women offender research has also supported this link (Harm \& Phillips, 2001; McLean, Robarge \& Sherman, 2006). Hser and colleagues (2003) found a connection between desistance and longer times in 
substance abuse treatment for both men and women offenders. Not using multiple drugs and greater treatment readiness were also desistance factors specifically for men and women, respectively. Peersen, Sigurdsson, Gudjonsson and Gretarsson (2004) did not separate their findings by gender but did find that substance abuse was related to outcome in their mixed sample. Uggen and Kruttschnitt (1998) did examine gender differences and discovered that, while substance abuse was related to self-reported arrest in both men and women, drug use was significantly more important in predicting re-arrest in women. They suggested this difference may be explained by gender norms that would dictate harsher treatment of women who abuse substances, compared to male drug users. They also indicated that this illustrated the problem that may arise when using official data to determine factors related to desistance; correlates of arrest may reflect societal responses to offenders rather than the conditions that determine criminal behaviour.

Research has also shown gender differences in the nature of substance abuse, as opposed to its relationship with measures of desistance. Motiuk (1997) found that male offenders were assessed upon admission to prison as having more needs in the area of substance abuse than women offenders. Pelissier and Jones (2005) reviewed addictions research and determined that while men had more serious criminal histories, substance abusing women experienced more employment problems and abuse, and had more child care responsibilities and substance abuse problems in their families. Furlong and Grant (2006) also found that substance abusing women offenders often have relatives and partners who abuse substances, and their substance abuse has been linked to past trauma and abuse and to subsequent criminal acts. Falkin and Strauss (2003) specifically examined the role of relationships in women's substance abuse, and found that 
relationships often hindered the recovery process for women. Even seemingly supportive relationships with non-using individuals could facilitate substance abuse; for example, by providing financial assistance they may be unintentionally funding a habit and by offering child care they may unintentionally be providing the opportunity to use.

The extant literature on employment shows great philosophical and qualitative support for its influence on women offender desistance but empirical research has demonstrated mixed findings and may reflect differences in measures and data that are more sensitive to male offender employment needs and experiences. The research seems to highlight the importance of making meaningful and responsible choices regarding substance use/abuse to women offenders' outcomes, and research suggests relationships may be particularly important to their recovery from substance abuse. While the substance abuse literature has shown the negative impact that relationships can have on women's substance abuse and subsequent criminal behaviour, there is research that suggests relationships play a very positive role in the reintegration of women offenders. The following section reviews literature related to the influence of relationships based on respect, dignity, and providing a supportive environment.

Respect, Dignity, and a Supportive Environment

The Creating Choices principles of respect and dignity and a supportive environment encompass relationships among women offenders and between women offenders and staff. Relational theory suggests that positive relationships and connections with others are particularly important for the healthy development and functioning of women (Covington, 1998). Desistance research has demonstrated an empirical link between relationships and offender outcomes for men (Haggård, Gumpert 
\& Grann, 2001; Laub, Nagin \& Sampson, 1998; Sampson \& Laub, 1990) and women (Gottschall \& Serin, 2008; Verbrugge et al., 2002). Stouthamer-Loeber et al. (2004) failed to find a connection between relationships and desistance in a sample of male offenders, but the quality of these relationships may not have been assessed, as they were in some other studies showing this link (e.g., Sampson \& Laub, 1990). Through interviews with 413 male offenders, Naser and La Vigne (2006) found that offenders expected family support in the areas of housing, and financial and emotional support upon release. Moreover, pre-release expectations of family support were often exceeded and the importance of family support to their success was rated higher post-release than pre-release. However, Naser and La Vigne indicated African Americans were overrepresented in their sample and the effects of race/ethnicity on desistance factors in male offenders were unknown. In a mixed-gender study that failed to find a connection between relationships and desistance, Giordano, Cernkovich and Rudolph (2002) suggested that the racial/ethnic heterogeneity of their sample may have affected their results.

Mixed-gender research has given mixed results for the link between relationships and success upon release. Hser et al. (2003) found relationships with children to impact post-release success for male offenders but not women offenders, while Benda (2005) found relationships with partners, friends and family to be better predictors of outcome for women offenders than male offenders. Both studies included large samples, but the former study involved a sample of substance-abusing offenders while the latter specifically excluded substance abusers from the study; it is possible that this difference may account, at least in part, for the discrepancies in the findings, especially given 
previous research showing the difficulties relationships can present to women's recovery from substance abuse. Motiuk (1997) found that women were assessed upon admission to prison as having greater needs than male offenders in the areas of relationships with associates and significant others; however, this gender difference was not examined in relation to offender outcome. Kosterman et al. (2005) discovered a weak association between distal social relationships with groups and neighbours and desistance in male and female offenders, but no gender differences in desistance factors were examined. It was found, however, that women invested more in closer relationships while men invested more in distal relationships.

Uggen and Kruttschnitt (1998) found mixed results based on their different measures of desistance; gender differences were found with self-reported illegal earnings but not self-reported arrest. Women's illegal earnings were inversely related to having pro-social associates and relationships with children, and the influence of relationships with children was a significantly greater predictor for women's success than men's. Relationships with children were not significantly related to self-reported arrests for either men or women. Again, it was suggested that discrepancies between the correlates of the two measures reflected the difference between societal reactions to offenders and conditions related to offenders' actual behaviour.

Interviews with a small sample of male and female burglars showed that while relationships with partners and children were associated with positive outcomes for the male offenders, women offenders needed to sever many of their relationships, which were often with criminal partners, in order to avoid criminal behaviour (Mullins \& Wright, 2003). De Li and Layton MacKenzie (2003) produced similar findings through 
interviews with 125 probationers. Social bonds were inversely related to criminal behaviour and drug use was a moderate facilitator for male offenders, while for women offenders, both social bonds and drug use were strong facilitators of criminal activity. The strongest link to outcome for men was living with a spouse, followed by having a job or going to school, while the strongest link for women was school, then living with a spouse, and finally having a job. De Li and Layton MacKenzie suggested their findings reflected greater antisocial tendencies for men; any increases in social bonds would be expected to have a dramatic positive impact on their outcomes while the more pro-social women offenders would not experience any great changes in their bonds or their outcomes upon release. They also hypothesized that the employment/school link to criminal behaviour found for women offenders in this study supported emancipation/liberation theory, which posits that with increased educational and occupational opportunities for women come greater opportunities for more serious crime. However, it may also reflect the poor nature of the education or employment available to these women; if these women are relegated to 'pink-collar' jobs, they may still find it necessary or expedient to commit certain profit-driven crimes. It should also be noted that only a quarter of their sample was composed of women offenders.

Other researchers have explained gender differences through a discussion of the nature of women's relationships. Giordano, Cernkovich and Holland (2003) found criminal behaviour to be associated with criminal partners and peers for both male and female offenders but found a much weaker association for women than men. They suggested women may be less likely to have pro-social partners and peers because of the social stigma attached to women offenders based on gender norm violation and because 
of the lower proportion of non-criminal partners available to women compared to prosocial female partners available to men. They discussed the possibility that women may succeed despite these poor relationships because of their motivation to desist based on their roles as mothers, and because of other factors, relating to attitudes and personal agency.

Leverentz (2006) conducted interviews which revealed that relationships could be either helpful or harmful for women offenders, but even relationships with partners with criminal histories could be supportive at times. Leverentz explained this by identifying relationships as dynamic processes, which can provide positive and negative influences at different times. Within the small sample of women interviewed, there were some who found it helpful to avoid partners though, since women's offending was often linked to relationships with criminal partners; male offenders often have partners involved in the desistance process but their role in offending was most often insignificant. Like Giordano, Cernkovich and Holland (2003), Leverentz (2006) suggested other desistance factors may be more important to counteract the influence of negative relationships or replace the influence of positive relationships the women are unable to develop; these other factors may include attitudes and personal agency or other social bonds and relationships. Based on these suggestions, it may be hypothesized that the relationship between women offenders and their parole officers or other support staff in the community upon their release may be that much more important than the same relationship for male offenders.

Research on exclusively female samples seems to support this explanation. Sommers, Baskin and Fagan (1994) determined that a small sample of women offenders 
interviewed showed a similar three-step process of desistance to that shown by male offenders. This involved developing a motivation to cease offending, a public decision or declaration to change and the creation of a new pro-social identity (e.g., through physical removal from previous situations, locations, and associations), and finally, the ongoing maintenance of their new identity through new social networks. It was found that support groups and treatment groups were helpful in the final step of pro-social identity maintenance for most of the women. Harm and Phillips (2001) conducted interviews with women offenders and found that women described relationships as being an important factor in their post-prison success. The women also seemed to perceive parole officers as playing a key role, although their assessments of the quality of their parole officers seemed mixed; when asked what resources would have helped the women avoid incarceration, $11 \%$ of the 38 women suggested a 'better' parole officer. Some women found their parole officers helpful while others found them either too lenient or too strict, particularly as it related to reactions to failed urinalysis and drug testing.

Other research on women offenders has found different factors to relate to the amount or the influence of social support on women's reintegration in the community. Bresler and Lewis (1983) found that African American women offenders were more likely to come from broken homes but still had closer ties to family and expected more familial assistance upon release than Caucasian women. Although the influence of these differences on desistance was not assessed in this study, it was assumed that more positive ties would generate greater success. On the other hand, Katz (2000) found that race/ethnicity determined the impact of social capital, including relationships, on women offender desistance, with Caucasian women's outcomes more closely tied to social 
capital. It may be that while African American women have more support, Caucasian women benefit more from the support they receive; this is similar to research suggesting the greater effect of any increases in social bonds on male offender outcomes given their low connectedness to others, compared to women (De Li \& Layton MacKenzie, 2003). It must also be remembered that research suggested that non-romantic relationships may still be more important for women offenders (e.g., Leverentz, 2006).

Reisig, Holtfreter and Morash (2002) interviewed 402 women and identified a relationship between socioeconomic status and the size of one's social support network. In this study it was also assumed that greater social support was indicative of higher success upon release, although this was not directly tested. Higher education and higher income were associated with larger social networks, while lower education, lower income and lower age were correlated with lower support. However, higher levels of program participation were also associated with greater support. These results seem to indicate that, while certain demographic factors may limit the support available to women or the quality and positive impact of that support, correctional practices and staff can play a role in addressing such deficits.

The role that parole officers may play in this area depends on the nature of their relationship with the offenders on their caseload. Such considerations may be seen as falling under the principle of responsivity in the aforementioned R-N-R model of effective correctional practice. Responsivity involves matching offender motivation, ability and learning style to the style and form of intervention employed (Andrews, 2001). While meta-analytic research has shown general responsivity to apply to women offenders, indicating that women are most likely to benefit from programs based on 
behavioural or social learning theory (Dowden \& Andrews, 1999), specific responsivity has not been tested in meta-analytic research. Compared to the general mode of treatment suggested by the general responsivity principle, specific responsivity relates more to the individual tailoring of treatment based on offender variables, such as personality, strengths, ability, and even gender and ethnicity (Andrews, 2001; Andrews \& Dowden, 2007). A primary qualitative study of an empowerment program for African American women offenders, which showed cultural sensitivity in its emphasis on African American inspiration and role models, showed the program was described by the women as helpful because of its responsiveness to their specific needs and their control over the content and methods used (O'Brien, 2001a). While this particular study did not examine the relationship between this program and offender outcomes, other qualitative research has suggested the importance of spiritual beliefs and practices as a source of strength for women offenders and a contributor to their success upon release, as described by the women themselves (Parsons \& Warner-Robbins, 2002). In addition to supporting the specific responsivity principle, these findings directly support the Creating Choices principle of respect and dignity, as it relates to respect of women offenders' spiritual beliefs and practices.

Among his principles of effective correctional programs, which included general and specific responsivity, Andrews (2001) highlighted the importance of staff, suggesting that staff should possess some combination of relationship skills, such as being respectful, open, warm, caring, empathetic, understanding, and flexible. Other desirable traits and activities included modelling prosocial attitudes and behaviours, assisting with problem solving, and advocacy/brokerage activities. A mixed-gender meta-analysis has 
also demonstrated that program integrity (including staff selection on the basis of such desirable characteristics) augments the positive effects of following the risk, need, and responsivity principles of effective correctional practice (Andrews \& Dowden, 2005).

The importance of these elements of the officer-parolee relationship has been recognized by practitioners and researchers. A parole officer at the Women's Supervision Unit in Toronto explicitly highlighted the importance of parolees feeling respected and for parole officers to show their belief in the offenders' strengths and ability to change, which is expected to build offenders' confidence and empower them to make responsible choices (Deguara, 2004). Reflecting on his own experience as a criminal justice social worker, McNeill (2004) criticized the predominant focus of corrections on problems and risks to the public interest, and even critiqued the focus of correctional research on programming. He suggested that the focus on general program effectiveness neglects the important aspects of the relationships between offenders and staff or case workers, as well as the individual needs of the offenders. He contended that the desistance process is not as simple and formulaic as providing a certain treatment at a particular dosage but involves nuances not captured by most program evaluations.

Maruna, Porter and Carvalho (2004) discussed the implications of the aforementioned Liverpool Desistance Study for probation practice. They suggested that the findings of optimistic biases in the life narratives of desisting offenders indicated the importance of probation officers focusing on offenders' strengths, building upon them, empowering offenders, and helping them to feel hope for their future and the confidence to move forward. Of course, this discussion could be extended to parole officers or other case workers assisting offenders in their reintegration into the community. Despite all of 
these suggestions, some have expressed concern that parole officers are unable to develop these positive relationships with clients because of budget and time constraints and/or policies that formally or informally discourage case workers developing close relationships with offenders (Burnett \& McNeill, 2005; Straussner \& Phillips, 2005). While a good number of practitioners and researchers have themselves written about the benefits of a positive relationship between offenders and their case workers, there is also a fair amount of interview and survey data that demonstrates the importance of this relationship, based on the perceptions of other case workers and offenders. Koons, Burrow, Morash and Bynum (1997) found that both women prisoners and "experts" at the prisons (e.g., wardens, state-level and program administrators) agreed that certain staff characteristics were important to the delivery of programs, including being caring, being women, and being former addicts and/or offenders, which allows them to be better role models for the women. The women and the experts also highlighted the importance of a positive and supportive environment needed to make the women feel comfortable, and the women offenders most often rated the staffing characteristics as being important to their success in their programs. While this research does not relate specifically to community supervision, it reveals the significance of women's relationships with staff and a supportive environment. A recent meta-analysis of program effectiveness based on certain principles of correctional practice also found that relationship factors were positively correlated with effect size (Dowden \& Andrews, 2004). In other words, programs with staff who showed warmth, empathy, respect and other positive qualities performed better. In non-correctional treatment literature, collaborative approaches in a mentoring program for female college students also found 
that a mentoring relationship characterized by authenticity, mutual engagement/empathy and empowerment was associated with positive outcomes (i.e., increased self-esteem and decreased loneliness), even when controlling for stress, race, year of study and structural qualities of the relationship such as frequency of contact (Liang, Tracy, Taylor, \& Williams, 2002).

In a study specifically examining parole, women offenders described positive relationships with parole officers as involving flexible and responsive parole officers who would treat them as people, respond to the women's difficulties by reconsidering their parole conditions and give them accurate information relating to these conditions (O'Brien, 2001b). Through interviews with probation officers and their caseloads of both male and female offenders, Rex (1999) found that most offenders liked probation officers who balanced engaging offenders with professionalism and formality. Offenders found it easier to commit to a crime-free lifestyle when their probation officers demonstrated commitment and support. A high percentage of offenders rated empathy (87\%), good listening skills (65\%) and being respectful (58\%) as being desirable traits of probation officers. Only $35 \%$ of offenders liked social distance from their probation officers and $65 \%$ liked formality. Guidance in problem-solving was also highly rated in importance. Rex concluded that probation officers underestimate the influence they have on probationers' actions simply by taking an interest in offenders and providing encouragement and support.

Seiter (2002) collected survey and interview data from parole officers related to the importance of their regular duties and concluded that the officers seemed to emphasize "casework" more than "surveillance." The former approach to community 
supervision encompasses assisting offenders and working with offenders to address challenges and problems that arise. The latter approach is focused on the monitoring and enforcement of conditions of the offenders' parole. Klockars (1972) discussed a model of community supervision in which a "synthetic officer" would balance the two seemingly competing and contradictory roles of surveillance and casework. The contradiction was discussed as arising from the need for officers to convince offenders to discuss their problems in order to address them through casework, and the need for officers to monitor and discipline offenders when such problems are disclosed. Synthetic officers would be able to balance these by introducing the department as a third party that requires officers to discipline offenders while officers wish to help offenders; a negotiation can then ensue which allows officers to both build a rapport with offenders and assist them, as well as motivate them with the threat of possible revocation and sanctions.

Studies have shown that officers often follow this kind of balanced supervisory model. Seiter and West (2003) found that 114 probation and parole officers surveyed estimated that on average they spent $55.9 \%$ of their time on casework activities and $41.4 \%$ on surveillance. During interviews with a reduced sample of 11 probation and parole officers, it was indicated that the offender and offense type tended to dictate the supervision style employed but that larger caseloads presented obstacles to adopting a casework approach, even though many believed casework was a positive approach in the long term. The majority of the reduced sample (54\%) expressed equal support for both styles. A high percentage (63.6\%) of those interviewed did not believe there was a relationship between supervision style and recidivism, but this was a very small sample. 
There is research, however, that suggests supervision style does have an effect on offender outcomes. Paparozzi and Gendreau (2005) studied a sample of high-risk parolees and determined that parole officers with a balanced orientation, combining surveillance and casework, had the greatest reductions in recidivism among their caseloads in a twelve-month follow-up. This study did include women offenders, but a very small number, and gender differences were not examined.

Probation officer empathy and socialization or endorsement of conventional values/attitudes have been linked to offender outcomes through a two-way interaction (Andrews, 1980). Probationers had lower recidivism when paired with probation officers with greater socialization and empathy or, to a lesser degree, low socialization and lower empathy. Higher socialization with low empathy, and low socialization with greater empathy were associated with higher recidivism. The optimal conditions of higher socialization and higher empathy were also associated with lower endorsement of criminal attitudes and higher endorsement of pro-social attitudes in probationers, even when controlling for variables such as probationer age, gender, pre-scores, and the professional status of the probation officer.

Trotter (1990) also found that pro-social probation officers, or those with high socialization, were the most effective, providing role models for their clients, which resulted in lower recidivism rates and less serious offences among those who recidivated. Empathy was not found to influence offender outcomes, however. In another study, probation officer approach in terms of being pro-social, having a problem-solving focus, and showing empathy was associated with lower recidivism among their caseloads (Trotter, 1996). The pro-social approach by officers was also found to have more of a 
positive impact than problem-solving or empathy, and empathy on its own failed to have a significant effect. However, this study failed to examine the influence of gender or even indicate the gender composition of its sample.

Research on probation and parole officers in general has seemed to suggest that officer traits in the areas of conventionality and assistance with problem-solving have a direct link to offender outcomes, while empathy plays a role in combination with these other traits, although the influence of gender has not been directly examined. Interview and survey data also suggest that both practitioners and offenders (of both genders) value empathy in community correctional officers, so its inclusion in the evaluation of the Creating Choices principles of respect, dignity and a supportive environment may still be deemed appropriate. The importance of relationships in general to women offender desistance has both philosophical and empirical support. Relational support has been linked to empowerment in the health empowerment (Crawford Shearer, 2004; Crivelli Kovach, Becker \& Worley, 2004) and general empowerment (Bowers Andrews, Guadalupe \& Bolden, 2003) literature. Organizational support and recognition has also been linked to empowerment for women in the workplace (Patrick \& Spence Laschinger, 2006; Yoder, Schleicher \& McDonald, 1998) and has been linked to desistance in correctional research on the influence of identity and agency (e.g., Maruna \& LeBel, 2003; Maruna et al., 2004). A discussion of research relating to the final Creating Choices principle of shared responsibility follows.

\section{Shared Responsibility}

Given the interconnected nature of the five principles of Canadian federal correctional practice for women offenders, it is not surprising that much of the research 
already discussed in relation to the previous four principles also relates to the principle of shared responsibility. Dowden and Andrews' (2004) meta-analysis of program effectiveness failed to demonstrate a significant relationship between the utilization of community resources (e.g., through referrals) and the effect size for the correctional intervention. However, Dowden and Andrews recognized the fact that such an effect would be limited by the availability of community services and resources and this may be reflected in their findings.

Some research suggests that parole officers may not be keeping parolees informed of all the available resources, however. Delveaux, Blanchette and Wickett (2005) found that women offenders in the community were most likely to learn of Community Employment Centres, which assist offenders in creating résumés, job searches and other employment-related activities, from other community agencies or sources other than parole officers. Staff members indicated that community resources were inadequate in the area of employment services. Delveaux, Blanchette and Wickett recommended that greater links be established between correctional staff and community services to ensure appropriate follow-up and support upon release, not just for employment but also other areas of need that impact on women's success in employment and their overall reintegration (i.e., substance abuse). They suggested that this may be of particular importance in areas where there are smaller numbers of women offenders in the community and women offender-specific correctional programs/services are not available upon release.

Richie's (2001) interviews with a small sample of women offenders revealed barriers for women offenders in obtaining community services, even where they are 
available. She found that certain systemic barriers existed that excluded women from victims' services in the community on the basis of their criminal past, despite the fact that many women offenders are themselves victims and may require such support to live healthy and productive lives. Richie also discussed women offenders being denied public funding and low-income housing on account of their criminal history. However, these barriers may be more applicable to community services in the United States, where these interviews were conducted. In any case, several researchers have explicitly called for more community resources for women offenders to ensure a smooth transition to the community and appropriate support (Krienert \& Fleisher, 2001; Wilson \& Anderson, 1997). The importance of community linkages has even recently been suggested as a principle of the R-N-R model of effective correctional practice (Andrews \& Dowden, 2007) and further research has been recommended in this area (Wormith, Althouse, Simpson, Reitzel, Fagan, \& Morgan, 2007).

Practitioners have also specifically recommended the inclusion and greater involvement of community groups and agencies in the reintegration of offenders. Some have recommended concrete supports such as support groups in offenders' neighbourhoods or partnerships with employers (Court, 2004), and others have suggested that even specific support groups related to specific offender needs can have a general effect of providing more inclusion and less isolation for offenders (Cluley, 2004). In interviews with parole officers, Seiter (2002) also found that they mentioned referrals to community agencies as part of the "casework" duties they considered so important to their work. 
It would appear that there is a great deal of support among practitioners, researchers and theorists for maintaining links to community resources in assisting offender reintegration. However, it has been suggested that barriers may exist in connecting offenders with these resources, including systemic barriers, the unavailability of certain services and unawareness of such services. These barriers may have contributed to the disappointing findings of the only meta-analysis known to the author to examine the effect of community referrals and links to offender success (Dowden \& Andrews, 2004). Despite the problems associated with its implementation, shared responsibility in the reintegration of offenders is widely seen as a desirable goal, and its inclusion among the five principles of Creating Choices is understandable. It was included in the current examination of these principles as they currently operate in community corrections for federally-sentenced women in Canada. The specifics of this current study are discussed in the following section.

Current Study

\section{Study Rationale}

Given the problems surrounding conditional release for women offenders, particularly related to staff issues, that have been revealed in numerous government reports, an investigation in this area is warranted. Research has provided strong philosophical and some indirect empirical support for the five principles of Creating Choices so an examination of adherence to these principles may be expected to relate to offender outcomes and have some bearing on the aforementioned problems. Researchers and practitioners alike have explicitly supported empowerment in working with women offenders and empowerment has been seen to include self-esteem and internal locus of 
control or belief in one's control over one's own life, which have been linked to desistance in women and male offender populations.

Meaningful and responsible choices related to employment and school had mixed findings with some suggesting the link does not apply to women but gender differences were either non-significant or not tested for significance. The relationship was also found to depend on the dependent measures used and the possible influence of race/ethnicity was suggested. Women-specific research does generally support the link. Substance abuse was also found to relate to desistance; it hindered desistance or the ability to make meaningful and responsible choices in both men and women. Some gender differences were found in the nature of substance abuse, however, particularly in the influence of relationships, which often facilitate substance abuse in women.

Research on the third and fourth principles of Creating Choices related to relationships showed mixed findings with relational theory and some studies showing relationships more important to women offender desistance, others showing antisocial relationships can be more detrimental for women, and still others finding relationships to not impact women's outcomes either way. It was suggested that partner relationships were particularly unhelpful for women and other factors, such as agency or attitudes and other social bonds, may be more important for women. These other social bonds may include relationships with parole officers, which can compensate for the poor social capital available to women on account of factors, such as socioeconomic status. Many in the field stress the importance of this relationship, including offenders themselves. Research on community supervision has included recommendations that parole officers be selected with characteristics that may be seen as consistent with Creating Choices, 
including showing empathy, and providing guidance in problem-solving and pro-social modelling. These characteristics have been connected to outcome to varying degrees and in combination. Finally, research has failed to show a link between utilization of community resources and desistance, perhaps due to problems in availability and barriers to its use. It has, however, been commonly recommended.

Research has generally shown philosophical and some empirical support for these principles but too little research has focused on women specifically. Women are more often included as minorities in mixed-gender samples or used to control for gender, rather than to examine gender differences or women's unique experiences. Even research specifically on women rarely assessed the relationship between women offenders and their parole officers, and none have couched such an assessment in the language of Creating Choices. The current study aimed to fill this gap by looking specifically at women offenders and gender differences in the presence of indicators of these principles in interactions with parole officers and the effect of the presence/absence of these indicators.

Hypotheses

It was generally hypothesized that more indicators of the five principles would be present in interactions between women offenders and their parole officers than between male offenders and their parole officers. Given research showing support for the five principles in both women and men, it was also hypothesized that more indicators would be linked with positive outcomes for both groups. Given the principles' explicit link with women offenders in Creating Choices and research suggesting the social bonds outside of 
the family (e.g., with parole officers) are more important for women offenders, it was further hypothesized that the link would be stronger for women offenders.

\section{Method}

\section{Participants}

Parole officers were recruited through the support of the Correctional Service of Canada's National Headquarters, and parolees were recruited through participating parole officers. Six sites were chosen based on the high numbers of women parolees at each of these parole offices - Moncton, Hamilton, Edmonton, New Westminster, Ville Marie and a Women's Supervision Unit in Toronto. Participants included 9 women parolees, 27 male parolees and 10 parole officers ( 4 male and 6 female). Two parole officers had only female parolees on their caseload, while 4 had only males and 4 had a mixed-gender caseload. When restricted to those parolees with outcome data available, the sample of parolees was limited to 28 parolees and the sample was limited to 8 parole officers with outcome data available for those offenders on their caseload that participated in the study with follow-up data available.

The average age of parole officers was 39.60 years $(\mathrm{SD}=9.88)$, and the average age of parolees was 39.69 years $(\mathrm{SD}=0.12)$. The majority of parolees $(n=24)$ were Caucasian, followed by Aboriginal (including Metis; $n=3$ ) and mixed-ethnicity $(n=2)$. All other ethnic categories had frequencies of one or less. Eight parolees completed French questionnaires, and 28 completed English questionnaires. All parole officers completed English questionnaires. Twelve (26.10\%) participants were from Moncton, 3 $(6.50 \%)$ were from Edmonton, 21 (45.70\%) were from New Westminster, $9(19.60 \%)$ were from Ville Marie, and 1 (2.2\%) was from the Women's Supervision Unit in 
Toronto. Unfortunately, low response rates resulted in the low sample size and the particularly low number of women parolees included in this study. One parole officer from Moncton provided information on recruitment; there were 13 parolees to approach for participation, 9 of these were approached and 5 agreed to participate. No other parole officers provided information on response rates.

\section{Measures}

Three scales related to the parole officer-parolee relationship were administered to parole officers who agreed to participate and two of these scales were completed by offender volunteers from their caseloads. Offender volunteers also completed a questionnaire related to self-esteem and another on motives for substance use.

Dual Role Relationship Inventory - Revised. The first measure, the Dual Role Relationship Inventory - Revised (DRI-R; Skeem, Eno Louden, Camp \& Polaschek, in press), which was administered to both offenders and parole officers, is still in its infancy and little research is available on its psychometric properties. The scale has thirty-five items, which were tailored to either parole officers or offenders, and which were rated from 1 to 7 in terms of their applicability to the parole officer-parolee relationship. For example, one item for parole officers (POs) was "I consider a client's view," and its counterpart on the parolee form was "My PO considers my views," and each was rated as applying from 1 or "never" to 7 or "always." The items were divided into 3 subscales for Caring/Fairness, Trust, and Toughness, and total scores were the sums of item ratings with reversed ratings for the Toughness items (see Appendix A for a list of these items). Previous research has indicated the original scale and subscales have high internal consistency with alphas of $.95, .96, .90$, and .87 , for the total scale, Caring/Fairness, 
Toughness, and Trust, respectively (Skeem, Eno Louden, Camp \& Polaschek, in press). The scale has also been found to relate to offender outcomes, including probation violations and revocations (Skeem et al., in press).

Some items were modified for clarity for the purposes of this study and several items were added by the original authors to the originally published scale ${ }^{1}$. The original scale was developed and validated with a large mixed-gender sample (39\% and $42 \%$ female for development and validation samples, respectively), which made it particularly appropriate for its use in examining gender differences in the current study. The use of this scale provided a further examination of its relationship with outcome for offenders (male and female). The scale was expected to give an indication of the overall quality of the relationship between parole officers and their clients, and the connection between scores and outcomes was expected to reflect the influence of the Creating Choices principles generally.

Parole Officer Punishment and Reintegrative Orientation Questionnaire. Another scale, the Parole Officer Punishment and Reintegrative Orientation Questionnaire (POP-ROQ; Dembo, 1972), was completed by just the parole officers and measured parole officer orientation. Items were adjusted to ensure gender-neutral language. The full scale items are shown in Appendix B. Parole officers were presented with two opposing statements and asked to indicate where on a continuum (from 1 to 7 ) between the two poles their attitudes lie. Higher total scores indicated more of a reintegrative approach, as opposed to a punishment approach, and a reintegrative approach was considered more in keeping with the principles of Creating Choices. An example of a pair of opposing statements from this scale is "The causes of crime are 
located in factors internal to the offender" and "The causes of crime are to be found in factors external to the offender." Dembo (1972) found that the items for each dimension of PO orientation were significantly correlated and the two orientations were independent of one another. Dembo suggested that research should examine the influence of PO orientation on parolee outcomes. Paparozzi and Gendreau (2005) found that parole officers with an orientation balanced between punishment and reintegration had the most successful caseload. Their study involved a mixed-gender sample, but few women were included. The current study investigated the relationship between this scale and outcome, and this relationship was also expected to show the influence of the principles of Creating Choices (associated with a reintegrative orientation).

Creating Choices Principles Questionnaire (CCPQ). A new scale was created to assess the presence of each of the five principles in the working relationship between parole officers and their clients. The scale was necessary given the difficulty associated with tailoring existing scales to the principles while attempting to reduce overlap between the principles. A full list of the items is shown in Appendix C, divided into subscales for the five principles. All subscales have five items. Similar to the DRI-R, the scale had parallel items for parole officers and parolees, which were rated from 1 to 7 based on their applicability to the relationship (from 1 or "never" to 7 or "always"). An example of an item for Empowerment is "I help my clients to feel they are in control of their lives in a positive way" for parole officers, and "My PO helps me feel like I can control my life in a positive way" for parolees. One item on each subscale was reverse-coded, and higher total scores on each subscale indicated greater applicability of that principle, and higher scores on the overall scale indicated greater applicability of the Creating Choices

\footnotetext{
${ }^{1}$ The new scale was received from the original authors via e-mail.
} 
principles in general. It was intended that the current study would determine the relationship between scale and subscale totals (representing the Creating Choices principles) and offender outcome.

Rosenberg Self-Esteem Scale. Offender volunteers were asked to complete the ten-item Rosenberg Self-Esteem Scale (RSE; Rosenberg, 1965). This scale included both positively-worded items (e.g., "On the whole, I am satisfied with myself), and negativelyworded items (e.g., "I feel I do not have much to be proud of") related to self-approval. The full scale is shown in Appendix D. Items were rated on a five-point Likert-type scale (from 1 or "not very true of me" to 5 or "very true of me") used in a more recent examination of the scale (Robins, Hendin \& Trzesniewski, 2001). Negatively-worded items were reverse-scored and total scores then reflected the sum of the item ratings, with higher scores indicating higher self-esteem. The scale has been widely used (Robins, Hendin \& Trzesniewski, 2001) and has shown good internal consistency with reported alphas of 0.88 (Greenberger, Chen, Dmitrieva \& Farruggia, 2003) and from 0.88 to 0.90 over six assessments at different times in one study (Robins, Hendin \& Trzesniewski, 2001). The scale was included to assess gender differences in self-esteem and in the relationship between self-esteem and outcome; gender differences would support genderresponsive correctional practices (i.e., principles of Creating Choices) in general.

Drinking Motives Questionnaire. Offender volunteers also completed the fifteenitem Drinking Motives Questionnaire (DMQ; Cooper, Russell, Skinner \& Windle, 1992). The fifteen items were divided into subscales for three motives for drinking - social motives, motives relating to coping, and enhancement motives. All items began, "How often do you drink..." and ended with reasons related to the three motives. The social 
subscale tapped drinking related to social activities (e.g., "How often do you drink to be sociable?"). The coping subscale included items relating drinking to coping with negative affect/experiences (e.g., "How often do you drink to forget your worries?"). The enhancement subscale covers drinking for sensation-seeking or enjoyment (e.g., "How often do you drink because it's exciting?"). Items were rated on a four-point scale (from 1 or "never/almost never" to 4 or "always/almost always"). Subscale totals were created from the sum of item ratings for each subscale and higher totals indicated greater importance/applicability for that motive of substance use. The wording of the scale was modified to accommodate substance use in general, not just restricted to alcohol use; this modified scale has been used in previous studies (Bottos, 2007; Ward, Kersh \& Shanks, 1997).

The original scale has been found to have good internal consistency $(\alpha=0.77$, 0.81 , and 0.85 for the social, coping and enhancement subscales, respectively) and these findings were comparable across gender and race categories (Cooper et al., 1992). The modified scale for general substance use motives has also shown good internal consistency ( $\alpha=0.80,0.79$, and 0.82 for the social, coping and enhancement subscales, respectively; Ward, Kersh \& Shanks, 1997). The modified scale appears in Appendix E. The scale was included to assess gender differences in the nature of substance abuse and in the relationship between the nature of substance abuse and outcome; gender differences would support gender-responsive correctional practices (i.e., principles of Creating Choices) in general. 
Covariates. Questionnaires with offender demographics (i.e., age, index offence, race, socioeconomic status, marital status, employment, size of social support network) and parole officer characteristics (i.e., experience, size and gender composition of the caseload) provided the covariates included in follow-up analyses. See Appendix F for the full questionnaires. Offender Intake Assessment data from the Offender Management System (OMS) regarding offender risk and need assessments, release type, motivation and reintegration potential were also collected and assessed as covariates in analyses. The Offender Management System is a national database of information on all federal offenders (i.e., those with sentences of at least two years). The OIA is an assessment upon admission into custody designed to inform each offender's custodial placement and correctional plan (Motiuk, 1997). Global assessments of risk, need, motivation and reintegration potential are coded as low, medium or high, but assessments of specific need areas provide greater detail. Each domain is assessed as "factor seen as an asset to community adjustment," "no need for improvement," "some need for improvement," or "considerable need for improvement" (Motiuk, 1997). The seven areas covered in the OIA include substance abuse, employment, community functioning, marital/family, associates, personal/emotional, and attitude (Motiuk, 1997).

Also included in the OMS data were risk assessments based on the Statistical Information on Recidivism - Revised 1 (SIR-R1) scale. This scale estimates risk of reoffence within three years of release based on 15 items and has been widely used and validated on male offender samples (Nafekh \& Motiuk, 2002). The scale is not applied to women offenders; therefore, SIR-R1 scores were only included as a covariate for male offenders in the current study. 
Dependent variable. Multiple measures of offender outcome were combined in this study - revocations, new convictions, urinalysis test results, disciplinary interviews and other indications of failure included in parole officer observations in each offender's casework records in OMS. Based on this file information, 7 (25\%) of the 28 parolees (6 males and 1 female) were coded as failing. Parole officer responses on the three scales were linked to the outcome of their caseload defined as the proportion of their caseload with adverse outcomes based on the multiple measures. Only those of their caseload who agreed to participate (and allowed us access to information on outcome in their case files) were included. Each offender's responses on the DRI-R, the Creating Choices Principles Questionnaire, the RSE and the Drinking Motives Questionnaire were also linked to each offender's outcome as determined by these multiple measures. Follow-up periods differed between offenders; the beginning of the follow-up was marked by the beginning of their supervision under the parole officer who participated in this study and recruited them for this study, and the end of the follow-up was August 1, 2008, when offender files were accessed for outcome data.

\section{Procedures}

The six parole offices were contacted through the Correctional Service of Canada's National Headquarters and all parole officers were invited to participate in the study through a memo sent out in mid-May. Within a week of the memo introducing the project to the six sites, all study materials were mailed out to the parole offices. Those parole officers who agreed to participate signed a consent form (see Appendix G), which was returned in bulk with the completed scales. Due to the need to link the parole officers' responses to the success of their caseloads their responses could not be 
anonymous but were kept confidential and assurances of this were made. Parole officers with mixed-gender caseloads were asked to complete two sets of scales (one for each gender) if they believed their interactions with offenders varied by gender. Participating parole officers were asked to invite their caseload to participate and track this recruitment so response rates could be determined. Informed consent was obtained from parolees and included consent to access case files for follow-up. Parolees were also assured of the confidentiality of their responses and were asked to return their responses to the parole office, to be forwarded to the researcher. Where it was requested, pre-paid postage envelopes were provided to participants to facilitate the return of completed study materials. Informed consent forms with personal identifiers were stored separately from questionnaires, which could only be linked to personal identifiers on the informed consent forms through an identification number provided by the researcher. All materials were stored securely at the Correctional Service of Canada's National Headquarters. Parole officer and parolee participants were fully debriefed (see Appendix H) following receipt of their responses and the end date of the current follow-up (August 1, 2008). Offender records were accessed on or after August 1, 2008, and were coded for success/failure or desistance/persistence based on the previously discussed multiple measures of outcome up to the study end date of August 1, 2008.

\section{Data Cleaning and Analyses}

All analyses were completed with SPSS (v. 16). Tests of hypotheses were evaluated with a significance level of $\alpha=.05$, two-tailed.

Data cleaning. Reverse scoring was first applied to those items requiring the procedure, and these reversed items were included in scale and subscale total 
calculations. Prior to these total calculations, missing data were addressed for each scale individually, separated by the parole officer and parolee versions of each scale. Parolees missing responses for more than three items on the DRI-R (i.e., more than $10 \%$ of the scale items) were excluded from analyses with the scale. For those missing three items or less, the missing values were replaced with averages for those particular items. The same procedure was followed separately for parole officer responses on the DRI-R. The general rule of exclusion based on missing more than $10 \%$ of item responses was also applied to the RSE and DMQ for parolees, and the POP-ROQ for parole officers, and the CCPQ for parolees and parole officers separately.

Distributions were also assessed for normality, and log transformations were applied to those variables with significant ( $\alpha=.01)$ deviations from normality (i.e., number of supporters for parolees, number of female parolees for parole officers, and the Coping subscale total of the DMQ for parolees). The log transformations of these particular variables were used in subsequent analyses. Problems with normality persisted for most subscales of the DRI-R and CCPQ for parolees following transformation, which prohibited the use of analyses requiring normality with these subscales. Subsequent analyses focused on scale totals for this reason, with the exception of non-parametric analyses (e.g., Kendall's tau correlations with outcome). Homogeneity of variance was also assessed for distributions of variables used in those analyses requiring this assumption; when in violation of this assumption, alternative forms of the analyses available in SPSS (e.g., $t$-tests without equal variances assumed) were employed with no resulting problems. 
Psychometric analyses. Before hypothesis testing proceeded, the psychometric properties of the measures to be used in that testing were assessed. These analyses were designed to inform interpretations of results and inform future research involving these measures, particularly the newly-created CCPQ. Concurrent validity for the CCPQ was also assessed through correlations between CCPQ total scores and total scores on the DRI-R and POP-ROQ, given their assessments of the nature of the parolee-parole officer relationship. Correlations between CCPQ totals and RSE totals were also examined to assess concurrent validity, given the involvement of self-esteem in the empowerment principle (and other principles given the interrelationships among principles).

Adherence to Creating Choices. In order to assess the first hypothesis relating to gender differences in adherence to the principles of Creating Choices, independent samples $t$-tests were performed comparing scale totals (i.e., DRI-R, CCPQ) between male and female parolees. Correlations were also calculated between parole officer responses on the DRI-R, CCPQ and POP-ROQ separated by male and female parolees (with the same responses entered for both genders when parole officers did not indicate there would be a difference in their responses based on the gender of the parolees in question). Independent samples $t$-tests were also utilized to assess whether adherence to the Creating Choices principles differed based on parolee/parole officer perceptions/responses (i.e., DRI-R and CCPQ totals).

Assessing covariates. Point-biserial correlations were calculated between continuous covariates and dichotomous parolee outcome (success/failure), and chi-square tests for independence were used to test the relationship between categorical covariates and dichotomous outcome. Parolee covariates were linked with individual parolee 
outcomes and parole officer covariates were assessed in relation to parole officer outcomes (i.e., proportion of those on their caseload failing). The use of proportions to measure parole officer outcomes necessitated the use of Pearson correlations between parole officer continuous covariates and outcome and Kendall's tau correlations between categorical covariates and outcome. The significance of relationships between covariates and outcome was assessed to determine the need for their inclusion in analyses regarding independent variables' associations with outcome.

Associations with outcome and gender differences. In order to assess the second hypothesis that greater adherence to Creating Choices (i.e., higher scale totals) would be related to more positive outcomes for parolees, point-biserial correlations were calculated between scale totals and dichotomous parolee outcome. Correlations were also calculated between scale totals and parole officer outcomes (i.e., proportion of caseload failing). Correlations for parolee outcomes were calculated for parolees in general and separately for male and female parolees to facilitate the examination of gender differences. Significance tests of differences in correlations between scale totals and outcomes for males and females were also planned to assess the final hypothesis suggesting there would be a stronger relationship between Creating Choices (as reflected in scale totals) and outcome for women. Independent samples $t$-tests of RSE totals and DMQ subscale totals for males and females was also used as a general test of gender differences, which would support gender-specific practices (such as those reflecting Creating Choices principles), and point-biserial correlations between outcome and these scale and subscale totals were used to determine associations between these constructs and outcome (and gender differences in these associations, again, would support gender- 
specific practices). Finally, receiver operating characteristic (ROC) curve analyses were performed to assess the predictive accuracy of the scale/subscale totals for parolee outcomes, and gender differences were to be evaluated.

$$
\text { Results }
$$

\section{Psychometric Analyses}

Dual Role Relationship Inventory - Revised (DRI-R). Parolee responses on the DRI-R in the current study yielded Cronbach's alphas of $0.95,0.95$, and 0.97 for parolees, male parolees, and female parolees, respectively. All but 2 of the 35 item-total correlations were significant for parolees ( $r$ 's $=.41$ to $.85, p^{\prime} s<.05$ ), all but 3 were significant for male parolees $(r$ 's $=.47$ to $.90, p$ 's $<.05$ ), and all but 9 were significant for female parolees ( $r$ 's $=.71$ to $.92, p$ 's<.05). Complete tables with item-total correlations for the DRI-R can be seen in Appendix I. Parole officer responses on the DRI-R, specific to interactions with male parolees, yielded a Cronbach's alpha of 0.93 and 11 of the 35 items were significantly correlated with the scale total ( $r$ 's $=.69$ to $.91, p$ 's<.05). Parole officer responses on the DRI-R, specific to interactions with female parolees, yielded a Cronbach's alpha of 0.95 and 18 of the 35 items had significant correlations with the scale total $\left(r^{\prime} \mathrm{s}^{\prime}=.64\right.$ to $\left..88, p^{\prime} \mathrm{s}<.05\right)$.

DRI-R subscales showed good internal consistency with alphas of $0.94,0.93$, and 0.95 for parolees, male parolees, and female parolees, respectively, on the caring/fairness subscale. Parole officer responses on the caring/fairness subscale yielded alphas of 0.91 and 0.93 for interactions with male and female parolees, respectively. The trust subscale yielded Cronbach's alphas of $0.90,0.88$, and 0.98 for parolees, male parolees and female parolees, respectively. Alphas of 0.93 and 0.94 were calculated for the trust subscale for 
parole officer responses specific to male and female parolees, respectively. The toughness subscale yielded Cronbach's alphas of $0.75,0.74$, and 0.80 for parolees, male parolees, and female parolees, respectively. Parole officer responses on the toughness subscale yielded Cronbach's alphas of 0.46 and 0.62 for interactions with male and female parolees, respectively.

Parole Officer Punishment and Reintegrative Orientation Questionnaire (POP$R O Q$ ). Parole officer responses on the POP-ROQ in the current study, specific to interactions with male parolees, yielded a Cronbach's alpha of 0.63 , and only 2 of the 24 items had a significant correlation with scale totals $\left(r^{\prime} \mathbf{s}^{\prime} .72\right.$ to $\left..89, p^{\prime} \mathbf{s}^{\circ}<05\right)$. Complete tables with item-total correlations for the POP-ROQ can be seen in Appendix J. Responses on the scale specific to interactions with female parolees yielded a Cronbach's alpha of 0.59 , and only 6 of the 24 item-total correlations were significant $\left(r^{\prime} s=.68\right.$ to .87 , $p$ 's<.05).

Creating Choices Principles Questionnaire (CCPQ). Parolee responses on the CCPQ yielded Cronbach's alphas of 0.92 for all parolees and 0.92 and 0.95 for males and females, respectively. All but 2 of the 25 item-total correlations were significant for parolees in general ( $\mathrm{r}^{\prime} \mathrm{s}=.35$ to $\left..86, p<.05\right), 15$ items were significantly correlated with scale totals for female parolees ( $r^{\prime} \mathrm{s}=.76$ to $.96, p<.05$ ), and 21 items were significantly correlated with scale totals for male parolees $\left(r{ }^{\prime}=.47\right.$ to $\left..86, p<.05\right)$. Complete tables with item-total correlations for the CCPQ can be seen in Appendix K. Cronbach's alphas for parole officer responses were 0.87 for interactions with both male and female parolees. Only 6 item-total correlations were significant for parole officer interactions 
with male parolees ( $r$ 's $=.68$ to $.86, p<.05$ ), and only 10 of the 25 items were significant for parole officer interactions with female parolees $\left(r\right.$ 's $=.64$ to $\left..86, p^{\prime} s<.05\right)$.

The empowerment subscale was associated with Cronbach's alphas of $0.67,0.67$, and 0.72 for parolees, male parolees and female parolees, respectively. Parole officer responses on the subscale showed alphas of 0.59 and 0.58 for interactions with male and female parolees, respectively. The meaningful and responsible choices subscale yielded alphas of $0.72,0.67$, and 0.85 for parolees, male parolees, and female parolees, respectively. Alphas for parole officer responses were calculated as 0.60 and 0.55 for male and female parolee interactions, respectively. Alphas for the respect and dignity subscale were $0.88,0.88$, and 0.87 for parolees, male parolees, and female parolees, respectively. Parole officer responses on this subscale yielded alphas of 0.34 and 0.43 for interactions with male and female parolees, respectively. Supportive environment alphas were $0.77,0.75$ and 0.82 for parolees, male parolees, and female parolees, respectively. Corresponding alphas for parole officer interactions with male and female parolees were 0.33 and 0.47 , respectively. The shared responsibility subscale yielded alphas of 0.53 , 0.53 , and 0.76 for parolees, male parolees and female parolees, respectively. Cronbach's alphas for parole officer responses on the shared responsibility subscale were 0.71 and 0.69 for male and female parolee interactions, respectively.

Parolee responses on the CCPQ were not significantly correlated with the RSE $(r=0.16, p=.398)$, indicating some possible problems with concurrent validity. These problems remained when restricted to males $(r=0.39, p=.065)$ and females $(r=0.00$, $p=.995)$. The CCPQ totals were, however, significantly correlated with DRI-R totals for parolees $(r=0.93, p<.001)$, males $(r=0.92, p<.001)$ and females $(r=0.98, p<.001)$. Parole 
officer responses on the CCPQ were also significantly correlated with totals on the DRI$\mathrm{R}$ for interactions with male parolees $(r=0.85, p=.004)$, and female parolees $(r=0.87$, $p=.001$ ). Parole officer responses on the CCPQ were not, however, significantly correlated with totals on the POP-ROQ for interactions with male parolees $(r=0.22$, $p=.603)$ and female parolees $(r=0.22, p=.564)$.

Rosenberg Self-Esteem Scale (RSE). Data from the current study yielded Cronbach's alphas of 0.91 for parolees as a group, and 0.86 and 0.95 for male parolees and female parolees, respectively. All item-total correlations were significant for female parolees $\left(r^{\prime} s^{\prime}=.68\right.$ to $\left..97, p^{\prime} s^{<} .05\right)$ and male parolees $\left(r^{\prime} s=.53\right.$ to $.85, p$ 's $\left.<.05\right)$, and for male and female parolees combined ( $r$ 's=.61 to $.87, p<.05)$. Complete tables with itemtotal correlations for the RSE can be seen in Appendix L.

Drinking Motives Questionnaire (DMQ). Parolee responses in the current study yielded Cronbach's alphas of $0.90,0.92$, and 0.88 for social, coping and enhancement subscales on the DMQ, respectively. Significant item-total correlations were calculated for all of the five items on the social subscale for parolees in general $\left(r^{\prime} s=.81\right.$ to .91 , $p ' s<.05)$. Complete tables with item-total correlations for the DMQ subscales can be seen in Appendix M. All item-total correlations were significant for the coping subscale for parolees ( $r^{\prime} \mathrm{s}^{\prime}=.76$ to $\left..92, p^{\prime} s<.05\right)$, as were item-total correlations for the enhancement subscale ( $r$ 's $=.72$ to $\left..87, p^{\prime} s^{<} .05\right)$. Cronbach's alphas for male parolees for social, coping and enhancement subscales were $0.87,0.89$ and 0.90 , respectively. All social subscale item-total correlations were significant for male parolees $\left(r^{\prime} s^{\prime}=.73\right.$ to $.92, p$ 's $\left.<.05\right)$, as were item-total correlations for coping $\left(r^{\prime} s=.69\right.$ to $.89, p$ 's<.05) and enhancement subscales $(r$ 's $=.78$ to $.90, p$ 's<.05). Cronbach's alphas for female parolees for social, 
coping and enhancement subscales were $0.97,0.97$ and 0.88 , respectively. All item-total correlations were significant for female parolees' social subscale ( $r$ 's=.91 to .96 , $p$ 's<.05), and coping subscale ( $r$ 's $=.89$ to $.98, p$ 's<.05), and all but one item-total correlation were significant on the enhancement subscale $\left(r{ }^{\prime} s^{\prime} .81\right.$ to $\left..94, p^{\prime} \mathrm{s}^{<.05}\right)$.

\section{Adherence to Creating Choices}

No significant differences were found between male and female parolee scale totals for the DRI-R $(t(31)=-0.39, p=.701)$, and CCPQ $(t(30)=-1.01, p=.323)$. Significant positive correlations between parole officer responses on the DRI-R $(r=.98$, $p<.001)$, CCPQ $(r=1.00, p<.001)$ and POP-ROQ $(r=1.00, p<.001)$ based on their relationships with male and female parolees also failed to demonstrate gender differences in adherence to Creating Choices. Non-significant differences in independent samples $t$ tests also indicated a high degree of agreement between parolee and parole officer perceptions of adherence to Creating Choices in their interactions based on the DRI-R $(t(41)=-1.22, p=.229)$, and the CCPQ $(t(40)=-0.09, p=.928)$. Averages on the scales

were higher than the mid-way point on the range of possible scores (i.e., greater than 105 on the DRI-R, and greater than 75 on the CCPQ), indicating the possibility of strong adherence to the Creating Choices principles, as perceived by both parolees and parole officers.

Assessing Covariates

Non-parametric chi-square tests for independence failed to demonstrate a significant relationship between dichotomous parolee outcome and categorical covariates, with the exception of community functioning, as reflected in Table 1. These chi-square analyses must be interpreted with caution, however, given that a high proportion of low 
expected frequencies (i.e., more than $20 \%$ of cells with expected frequencies of less than 5) made all of these analyses unreliable. For this reason, these tests for independence were not separated by the gender of the parolees given the resultant reduction in sample size and decreases in expected frequencies. Point-biserial correlations failed to demonstrate a significant association between dichotomous parolee outcome and the continuous covariates number of supporters (log-transformed; $\tau=0.19, p=.285$ ), and age $(\tau=-0.05, p=.750)$. The non-significant results for number of supporters (logtransformed) remained when separated by males $(\tau=0.30, p=.152)$ and females $(\tau=$ $-0.32, p=.480)$. The non-significant relationship between outcome and age also remained when separated by males $(\tau=-0.01, p=.941)$ and females $(\tau=-0.35, p=.380)$. SIR-R1 scores were also not significantly associated with dichotomous outcome $(\tau=0.38$, $p=.063$ ) for males; SIR-R1 scores were not available for female parolees.

Table 1. Chi-square tests of independence between dichotomous parolee outcome and categorical covariates.

\begin{tabular}{lccc}
\hline Covariate & $n$ & $\chi^{2}$ & $p$ \\
\hline Index offence & 25 & 2.39 & .122 \\
Participant language & 28 & 3.11 & .078 \\
Source site & 28 & 6.58 & .087 \\
Gender & 28 & 0.28 & .595 \\
Ethnicity & 27 & 2.41 & .790 \\
\hline
\end{tabular}




\begin{tabular}{|c|c|c|c|}
\hline Income & 25 & 1.62 & .805 \\
\hline Marital status & 28 & 4.02 & .546 \\
\hline Employment status & 27 & 2.30 & .513 \\
\hline Type of release & 28 & 0.27 & .875 \\
\hline Risk at intake & 21 & 4.76 & .093 \\
\hline Need at intake & 21 & 0.04 & .983 \\
\hline Risk at release & 23 & 2.14 & .343 \\
\hline Need at release & 23 & 0.23 & .893 \\
\hline Reintegration potential & 23 & 0.37 & .832 \\
\hline Motivation level & 23 & 4.45 & .108 \\
\hline Employment need & 23 & 2.48 & .479 \\
\hline Marital/family need & 23 & 4.39 & .112 \\
\hline Associates need & 22 & 0.08 & .962 \\
\hline Substance abuse need & 22 & 3.38 & .184 \\
\hline Personal/emotional need & 22 & 2.47 & .291 \\
\hline Attitudes need & 22 & 4.14 & .247 \\
\hline Community functioning need & 22 & 6.26 & .044 \\
\hline
\end{tabular}

Note: low expected frequencies in the majority of cells (i.e., more than $20 \%$ of cells with expected frequencies of less than five) made these results unreliable.

No significant relationships were found through Kendall's tau correlations between parole officer outcomes (i.e., proportion of caseload failing) and the categorical variables caseload gender composition $(\tau=0.29, p=.487)$, parole officer gender $(\tau=0.20$, 
$p=.623)$, and source site $(\tau=0.20, p=.623)$. Pearson correlations did not demonstrate significant associations between parole officer outcome and years of experience $(r=$ $-0.73, p=.103)$, number of male parolees on caseload $(r=-0.01, p=.984)$, number of female parolees on caseload (log-transformed; $r=.796, p=.058$ ), and caseload size ( $r=0.69, p=.132$ ). A significant association was found between parole officer age and outcome ( $r=-0.82, p=.045)$ with greater ages associated with smaller proportions of the caseload failing. This significant correlation should be interpreted with caution, however, given that it is based on a small sample size ( $n=6$ parole officers) and may be spurious.

These overall results did not indicate a need to control for these covariates in analyses testing the significance of associations between indicators of Creating Choices adherence (i.e., scale totals) and outcomes. The small sample size would also not support the use of covariates.

\section{Associations with Outcome and Gender Differences}

Point-biserial correlations failed to yield significant associations between dichotomous parolee outcome and scale totals for the DRI-R $(\tau=0.14, p=.401)$, and $\operatorname{CCPQ}(\tau=0.07, p=.686)$. The non-significance of these associations remained when restricted to males $(\tau=0.17, p=.386$, and $\tau=0.06, p=.773$ for the DRI-R and CCPQ, respectively) and females $(\tau=-0.12, p=.770$, and $\tau=0.58, p=.143$ for the DRI-R and CCPQ, respectively). Given the non-significance of these associations for males and females combined and separately, significance tests of the differences in correlations between outcome and scale totals for the two genders were not performed.

An independent samples $t$-test between RSE totals for males and females failed to demonstrate gender differences $(t(9.71)=0.99, p=.347)$, so gender-responsivity in general 
could not be supported by these particular results. Gender differences were also not found in totals on the DMQ Social subscale $(t(30)=-1.18, p=.247)$, Coping subscale (logtransformed; $t(30)=-1.51, p=.141)$, and Enhancement subscale $(t(30)=-0.48, p=.632)$. Point-biserial correlations did not demonstrate a significant relationship between outcome and RSE totals $(\tau=0.09, p=.596)$, DMQ Social subscale totals $(\tau=0.22, p=.206)$, DMQ Coping subscale totals (log-transformed; $\tau=0.12, p=.479$ ), or DMQ Enhancement subscale totals $(\tau=0.18, p=.297)$. The non-significance of these correlations remained when separated by gender, as reflected in Table 2 .

Table 2. Correlations between scale and subscale totals and dichotomous outcome for male and female parolees.

\begin{tabular}{lllll}
\hline Gender & Scale/Subscale & $n$ & $\tau$ & $p$ \\
\hline Male & RSE & 21 & 0.22 & .254 \\
& DMQ Social & 21 & 0.19 & .335 \\
& DMQ Coping (log-transformed) & 21 & 0.02 & .933 \\
& DMQ Enhancement & 21 & 0.08 & .676 \\
& RSE & 6 & -0.58 & .143 \\
& DMQ Social & 5 & 0.50 & .277 \\
& DMQ Coping (log-transformed) & 5 & 0.63 & .157 \\
& DMQ Enhancement & 5 & 0.63 & .157 \\
\hline
\end{tabular}


Non-parametric point-biserial correlations between dichotomous outcome and parolee subscale totals also failed to demonstrate significant relationships. Outcome was not significantly associated with parolee responses on the DRI-R subscales Caring/Fairness $(\tau=0.19, p=.255)$, Trust $(\tau=0.07, p=.669)$, and Toughness $(\tau=-0.27$, $p=.146$ ). Nor was outcome related to parolee totals for the CCPQ subscales Empowerment ( $\tau=0.22, p=.215)$, Meaningful and Responsible Choices $(\tau=-0.02$, $p=.907)$, Respect and Dignity ( $\tau=-0.15, p=.437)$, Supportive Environment $(\tau=-0.07$, $p=.698)$, and Shared Responsibility $(\tau=0.33, p=.059)$. Correlations remained nonsignificant when separated by gender, as seen in Table 3 .

Table 3. Point-biserial correlations between subscale totals and dichotomous outcome for male and female parolees.

\begin{tabular}{lllll}
\hline Gender & Subscale & $n$ & $\tau$ & $p$ \\
\hline Male & DRI-R Caring/Fairness & 21 & 0.25 & .197 \\
& DRI-R Trust & 21 & 0.13 & .495 \\
DRI-R Toughness & 20 & -0.32 & .135 \\
CCPQ Empowerment & 20 & 0.26 & .204 \\
CCPQ Meaningful and Responsible & 20 & -0.03 & .868 \\
Choices & & & \\
CCPQ Respect and Dignity & 20 & -0.21 & .333 \\
CCPQ Supportive Environment & 20 & -0.08 & .675 \\
CCPQ Shared Responsibility & 20 & 0.27 & .171 \\
\hline
\end{tabular}




\begin{tabular}{|c|c|c|c|c|}
\hline Female & DRI-R Caring/Fairness & 6 & -0.12 & .770 \\
\hline & DRI-R Trust & 6 & -0.14 & .752 \\
\hline & DRI-R Toughness & 6 & 0.20 & .655 \\
\hline & CCPQ Empowerment & 6 & 0.60 & .137 \\
\hline & CCPQ Meaningful and Responsible & 6 & 0.39 & .351 \\
\hline & Choices & & & \\
\hline & CCPQ Respect and Dignity & 6 & 0.20 & .655 \\
\hline & CCPQ Supportive Environment & 6 & 0.30 & .488 \\
\hline & CCPQ Shared Responsibility & 6 & 0.58 & .143 \\
\hline
\end{tabular}

No significant associations were found between parole officer caseload outcomes and DRI-R $(r=0.51, p=.304$, and $r=0.67, p=144$ for interactions with male and female parolees, respectively), CCPQ $(r=0.58, p=.224$, and $r=0.63, p=.185$ for interactions with male and female parolees, respectively), and POP-ROQ $(r=0.36, p=.550$, and $r=$ $0.38, p=.524$ for interactions with male and female parolees, respectively) totals. No significant associations were found between parole officer outcomes and totals on the DRI-R and CCPQ subscales for interactions with male and female parolees (see Table 4). 
Table 4. Correlations between parole officer subscale totals (separated by interactions with male and female parolees) and parole officer outcomes.

\begin{tabular}{|c|c|c|c|c|}
\hline $\begin{array}{l}\text { Gender of } \\
\text { parolees }\end{array}$ & Subscale & $n$ & $r$ & $p$ \\
\hline \multirow[t]{9}{*}{ Male } & DRI-R Caring/Fairness & 6 & 0.36 & .481 \\
\hline & DRI-R Trust & 6 & 0.58 & .230 \\
\hline & DRI-R Toughness & 6 & 0.59 & 218 \\
\hline & CCPQ Empowerment & 6 & 0.34 & .506 \\
\hline & CCPQ Meaningful and Responsible & 6 & 0.74 & .094 \\
\hline & Choices & & & \\
\hline & CCPQ Respect and Dignity & 6 & 0.69 & .128 \\
\hline & CCPQ Supportive Environment & 6 & 0.55 & .255 \\
\hline & CCPQ Shared Responsibility & 6 & 0.38 & .458 \\
\hline \multirow[t]{9}{*}{ Female } & DRI-R Caring/Fairness & 6 & 0.62 & .188 \\
\hline & DRI-R Trust & 6 & 0.57 & .240 \\
\hline & DRI-R Toughness & 6 & 0.68 & .136 \\
\hline & CCPQ Empowerment & 6 & 0.45 & .367 \\
\hline & CCPQ Meaningful and Responsible & 6 & 0.80 & .058 \\
\hline & Choices & & & \\
\hline & CCPQ Respect and Dignity & 6 & 0.58 & .228 \\
\hline & CCPQ Supportive Environment & 6 & 0.68 & .136 \\
\hline & CCPQ Shared Responsibility & 6 & 0.38 & .458 \\
\hline
\end{tabular}


Non-parametric ROC curve analyses failed to demonstrate predictive accuracy significantly different from chance for the DRI-R and its subscales, the CCPQ and its subscales, the RSE, and the DMQ subscales (see Table 5). Given the lack of significant predictive accuracy demonstrated for males and females combined or separately, significance tests for gender differences in areas under the curve for each scale/subscale were not performed, nor were significance tests performed for differences in areas under the curve between scales.

Table 5. Results of receiver operating characteristic (ROC) curve analyses for scales and subscales in predicting parolee dichotomous outcomes.

\begin{tabular}{llllll}
\hline Scale & Group & $n$ & AUC & Standard & $p$ \\
& & & & Error & \\
& & & & & \\
\hline DRI-R & Parolees & 23 & 0.41 & 0.12 & .483 \\
& Male parolees & 17 & 0.38 & 0.14 & .421 \\
& Female parolees & 6 & 0.60 & 0.22 & .770 \\
& Parolees & 23 & 0.33 & 0.11 & .217 \\
DRI-R Caring/Fairness & Male parolees & 17 & 0.26 & 0.12 & .116 \\
& Female parolees & 5 & 0.75 & 0.22 & .480 \\
& Parolees & 23 & 0.37 & 0.11 & .334 \\
DRI-R Trust & Male parolees & 17 & 0.31 & 0.12 & .211 \\
& Female parolees & 5 & 0.62 & 0.25 & .724 \\
DRI-R Toughness & Parolees & 23 & 0.64 & 0.15 & .301 \\
\hline
\end{tabular}




\begin{tabular}{|c|c|c|c|c|c|}
\hline & Male parolees & 17 & 0.69 & 0.16 & .211 \\
\hline & Female parolees & 5 & 0.37 & 0.31 & .724 \\
\hline \multirow[t]{3}{*}{ CCPQ } & Parolees & 23 & 0.43 & 0.13 & .616 \\
\hline & Male parolees & 17 & 0.42 & 0.14 & .580 \\
\hline & Female parolees & 6 & 0 & 0 & .157 \\
\hline \multirow[t]{3}{*}{ CCPQ Empowerment } & Parolees & 23 & 0.34 & 0.11 & .225 \\
\hline & Male parolees & 17 & 0.32 & 0.12 & .216 \\
\hline & Female parolees & 6 & 0 & 0 & .157 \\
\hline \multirow{4}{*}{$\begin{array}{l}\text { CCPQ Meaningful and } \\
\text { Responsible Choices }\end{array}$} & Parolees & 23 & 0.51 & 0.12 & .908 \\
\hline & & & & & \\
\hline & Male parolees & 17 & 0.52 & 0.14 & .869 \\
\hline & Female parolees & 6 & 0.20 & 0.21 & .380 \\
\hline \multirow{4}{*}{$\begin{array}{l}\text { CCPQ Respect and } \\
\text { Dignity }\end{array}$} & Parolees & 23 & 0.58 & 0.13 & .544 \\
\hline & & & & & \\
\hline & Male parolees & 17 & 0.61 & 0.14 & .433 \\
\hline & Female parolees & 6 & 0.40 & 0.30 & .770 \\
\hline \multirow{4}{*}{$\begin{array}{l}\text { CCPQ Supportive } \\
\text { Environment }\end{array}$} & Parolees & 23 & 0.55 & 0.11 & .707 \\
\hline & & & & & \\
\hline & Male parolees & 17 & 0.56 & 0.13 & .680 \\
\hline & Female parolees & 6 & 0.30 & 0.26 & .558 \\
\hline \multirow{3}{*}{$\begin{array}{l}\text { CCPQ Shared } \\
\text { Responsibility }\end{array}$} & Parolees & 23 & 0.26 & 0.10 & .060 \\
\hline & & & & & \\
\hline & Male parolees & 17 & 0.30 & 0.12 & .174 \\
\hline
\end{tabular}




\begin{tabular}{|c|c|c|c|c|c|}
\hline & Female parolees & 6 & $\overline{0}$ & 0 & .157 \\
\hline \multirow[t]{3}{*}{ RSE } & Parolees & 23 & 0.42 & 0.15 & .570 \\
\hline & Male parolees & 17 & 0.33 & 0.14 & .248 \\
\hline & Female parolees & 6 & 1 & 0 & .157 \\
\hline \multirow[t]{3}{*}{ DMQ Social } & Parolees & 23 & 0.68 & 0.14 & .205 \\
\hline & Male parolees & 17 & 0.66 & 0.16 & .308 \\
\hline & Female parolees & 5 & 0.88 & 0.18 & .289 \\
\hline \multirow[t]{3}{*}{ DMQ Coping (log) } & Parolees & 23 & 0.60 & 0.14 & .484 \\
\hline & Male parolees & 17 & 0.51 & 0.15 & .934 \\
\hline & Female parolees & 5 & 1 & 0 & .157 \\
\hline \multirow[t]{3}{*}{ DMQ Enhancement } & Parolees & 23 & 0.66 & 0.15 & .257 \\
\hline & Male parolees & 17 & 0.57 & 0.17 & .643 \\
\hline & Female parolees & 5 & 1 & 0 & .157 \\
\hline
\end{tabular}

\section{Discussion}

Adherence to Creating Choices

No apparent gender differences were found in adherence to the principles of Creating Choices through DRI-R and CCPQ totals for male/female parolees and parole officer responses for interactions with male/female parolees, nor were differences apparent in parole officer responses on the POP-ROQ for interactions with male and female parolees. Given that averages on the scales were higher than the half-way point on the range of possible scores (i.e., higher than 105 on the DRI-R, and higher than 75 on the CCPQ) this may indicate that parole officer relationships with both males and females 
appear to be generally following Creating Choices principles, despite the principles' explicit association with women offender federal correctional policies. Given that much of the research presented in the introduction in support of these principles has been conducted on male offender samples (particularly the empirical support; e.g., Trotter, 1990, 1996), these results are encouraging, although surprising given the stronger emphasis on this quality of interaction for women offenders. This apparent focus on "casework" related principles and activities is consistent with previous research, indicating parole and probation officers view these sorts of activities (e.g., providing support, advocacy, and assistance while treating offenders with respect and dignity) as crucial to their work, even in research on parole officer interactions with male offenders (e.g., Seiter, 2002). Building on offender strengths and encouraging them to make positive changes in their lives (key elements of Creating Choices) has also been recommended by academics (e.g., Maruna, Porter \& Carvalho, 2004) and practitioners (e.g., McNeill, 2004) alike for offenders in general although it has been particularly emphasized in women offender correctional recommendations, in addition to Creating Choices (e.g., Deguara, 2004).

It is possible that these positive results have been influenced by a selection bias, however. The study relied on volunteer data, and it may be that only certain parole officers agreed to participate (e.g., possibly those with more time who would then also have more time to devote to developing such a positive relationship with parolees). It is possible that those parole officers then only recruited those parolees who may be more willing to participate and/or only certain parolees then agreed to participate, and this willingness of the parole officer to approach the parolee and the willingness of the 
parolee to participate may have been influenced by the quality of their relationship, which may have positively skewed the measures of that relationship. Alternatively, only those parole officers with more positive attitudes may have volunteered to participate.

However, it must be remembered that convenience could have potentially skewed the results negatively. For example, if time constraints led to parole officers recruiting those parolees on their caseload with higher frequencies of contact (i.e., those at higher risk who thus may not have a high quality relationship with their parole officer), then this may be expected to attenuate consent rates and also lower scale totals for parolees, so the apparent high totals on the scales may not be artificially inflated by selection. Not enough information on recruitment and response rates was available to evaluate the likelihood of a selection bias influencing the results.

No significant differences in parole officer and parolee perceptions and responses on the DRI-R and CCPQ were apparent. This was an encouraging finding in that it indicated a mutual understanding of the relationship, possibly reflecting good communication and interpersonal skills on the part of the parole officer, which have been recommended as part of the principles of effective correctional practices (e.g., Andrews, 2001). It may be that this positive finding was unrepresentative, however, given the aforementioned possibilities of a selection bias in the data. Aside from this selection bias and the possible unrepresentativeness of these apparent positive relationships, it is also possible that other factors may have skewed participant responses such that they may not actually reflect positive relationships. For example, it may be that parolees were motivated to present their interactions with parole officers in a more favourable light (e.g., more emphasis on providing support than punishment, consistent with Creating 
Choices) because of feared reprisals from their parole officers (e.g., not receiving weekend passes or not reducing conditions or frequency of contact) if their relationship was depicted unfavourably. Parole officers may also have been concerned that if their responses reflected a poor relationship with parolees this may have a negative impact on their performance evaluations and possible career advancement. Parolee and parole officer participants alike were assured that their responses would have no bearing on their parole experiences and careers, respectively, and those with concerns regarding confidentiality were provided with pre-paid postage envelopes so their responses would be forwarded directly to the researcher, rather than through the parole office (although those at the parole office were clearly instructed not to review participant responses).

Despite these assurances and the procedures put in place to ensure confidentiality, it is possible that responses may still have been influenced by these considerations to some degree, although it seems more likely that those individuals with these concerns would have simply not participated at all. The small sample size and apparent low response rates may reflect this issue. The high degree of agreement between parole officers and parolees would also suggest that both groups would have had to be influenced by these concerns in order to falsely generate these positive results with significantly high correlations between groups. There is no information in the data that could substantiate these possible explanations regarding unduly positive depictions of the relationships between parole officers and parolees, but there is the potential for these influences to have played a role. 


\section{Assessing Covariates}

Chi-square tests of independence of categorical covariates and dichotomous outcome for parolees were unreliable given high proportions of low expected frequencies but point-biserial correlations between continuous covariates and outcome were reliable, albeit non-significant. The non-significance of the relationships between these continuous covariates and outcome may have reflected limitations of the data more than a lack of relationship between these variables. Even covariates that have been wellsupported in the literature (e.g., age; Verbrugge et al., 2002) were not significant, and this may have been influenced by the small sample size and reductions in power, as well as the possible unrepresentativeness of the sample with regard to these covariates given the possibility of a selection bias in volunteering.

A significant association between parole officer outcome and parole officer age should also be interpreted with caution given the limitations of the data and the possibility of a spurious correlation (e.g., this correlation was based on a sample of 6 parole officers). If one was to interpret the significant result at face value, it would indicate that older parole officers had lower proportions of their caseload failing; although years of experience was not significantly related to outcome, the greater age of those parole officers with more successful caseloads may result from greater life experience generally and the improved interpersonal skills that may result. Strong interpersonal skills for correctional staff have been recommended as part of the principles of effective correctional practices (e.g., Andrews, 2001). Given the non-significance of relationships between most covariates and outcome in this study and the limitations of the data, which made the significant relationship between one covariate and outcome suspect, 
outcome analyses with independent variables did not control for these covariates. The limitations of the data (i.e., small sample size) also prohibited the inclusion of many covariates in analyses with independent variables, and these analyses failed to demonstrate significant relationships between independent variables and outcome, even without controlling for these covariates. Associations with Outcome and Gender Differences

Correlations between scale/subscale scores and outcomes for parolees (i.e., success/failure) and parole officers (i.e., proportion of caseload failing) failed to demonstrate significant relationships. Receiver operating characteristic (ROC) curve analyses also failed to indicate predictive accuracy of scales and subscales to significantly deviate from chance. The significance of gender differences in these relationships between independent variables and outcome were not evaluated given the nonsignificance of these relationships for either group. In addition, no differences were found in self-esteem or RSE scores between males and females, nor were significant gender differences found in scores on the DMQ, which would have supported genderresponsivity in general. These scales were also not linked with parolee outcome.

While disappointing and contrary to the hypotheses of the current study based on a review of previous research, the current results did not suggest that higher scores on the scales (i.e., greater adherence to Creating Choices principles) were associated with parolee failure either. Therefore, given previous philosophical support and limited but promising empirical support for the hypothesized relationship between these principles and success (e.g., Andrews, 1980; Trotter, 1990, 1996), it would still be recommended that these principles be followed. Given analyses related to adherence, these principles 
appear to be followed for both male and female parolees, and given the current results and unsubstantiated gender differences in the importance of these principles to offender outcomes, this adherence is encouraging. Based on previous research and current results that do not significantly contradict this research, it would still be recommended that parole officer selection and training focus on interpersonal skills (e.g., treating others with respect and dignity, providing opportunities for offenders to make decisions and assisting in this problem-solving while building on and recognizing offender strengths). Policies and budgets should also allow for parole officers to develop these relationships (e.g., through smaller caseloads and increased time spent with and attention paid to each parolee).

When examining the non-significance of these results, the aforementioned explanations of possible selection biases and limitations associated with small sample sizes may still apply. While the current sample had a base rate of $25 \%$ failure for those 28 parolees with outcome data available, the selection bias may have played more of a role in restriction of ranges in responses on the scales and subscales, depicting overall positive relationships with parole officers that did not differentiate between those parolees who did well and who did not. Parolee and parole officer responses on the DRI$\mathrm{R}$ resulted in a range of total scores from 170 to 245 and 182 to 230 , respectively. All scores were then above the mid-way point on the total possible range of scores. The same was true for scores on the CCPQ (ranges of 117 to 161 and 129 to 165 for parolees and parole officers, respectively). The small sample size may have also restricted ranges in scale totals and reduced the power of analyses. Aside from sampling issues, the current results also highlight the difficulties of research in this area generally. One could 
view the influence of the parolee-parole officer relationship on offender outcome as a responsivity issue, particularly as it relates to gender responsivity (specific responsivity), and this area of research is not as well-developed as other research assessing principles of effective correctional practices (French \& Gendreau, 2003).

Some of the difficulty may arise from the measurement of these dynamic and multi-faceted relationships. Previous research has indicated that certain elements of the parolee-parole officer relationship are only associated with positive outcomes when in combination with other elements (e.g., empathy is only related to positive outcome when combined with pro-social modeling and/or problem-solving; Andrews, 1980; Trotter, 1996). The current measures essentially assume this pro-social modeling but may not assess it specifically, with the exception of measuring how approval/disapproval is given for pro-social/anti-social behaviour. However, previous research with the DRI-R has found scores to relate to outcome (Skeem et al., in press). This was not supported in the current study, but it was likely due to some of the data limitations and sampling limitations. Since the CCPQ and DRI-R were significantly correlated in psychometric analyses, it is entirely possible that given a larger sample size with less sampling bias, the CCPQ would have also been related to offender outcomes. Future research with larger sample sizes, facilitating stronger gender comparisons, may still support research suggesting the particular importance of the parolee-parole officer relationship (as a nonromantic social bond) to women offender outcomes (e.g., Leverentz, 2006). This research may also be facilitated by improvements to the measures based on current psychometric results (e.g., the modification or elimination of items with low item-total correlations). 


\section{Study Limitations}

The sampling method of this study was one of the main limitations. The sample of parole officers and parolees was not random and depended on the parole officer. This may have impacted the representativeness of the sample and limited the generalizability of the findings. For example, Aboriginal offenders were under-represented in the current sample, given that they comprised $8 \%$ of the sample, compared to $19 \%$ and $13 \%$ of women offender and male offender populations, respectively, in the community (L. Chatelaine, personal communication, October 28, 2007). This would have been of greater concern had there been significant findings in the current study.

The sample may have been biased because parolees may have been concerned about the confidentiality of their responses and how they may impact their experiences on parole. Parole officers may also have had confidentiality concerns relating to adherence to Correctional Service of Canada (CSC) policies, depictions of the quality of their relationships with parolees, and the reflection of their caseload successes on their work and careers. Every attempt was made to address these concerns and minimize their impact, including providing pre-paid postage envelopes when requested.

The use of parole officers to recruit parolees for participation was also a limitation, given the possibility that they may only approach successful parolees with whom they have good relationships; however, every attempt was made to prevent this through clear instructions for parole officers to approach all parolees under their supervision, and to track this recruitment. Response rate and recruitment information was provided by one Moncton parole officer and indicated a response rate of over $50 \%$ for those parolees asked to participate but not all parolees were asked and this 
information from one parole officer is insufficient to determine the extent of a possible selection bias and its impact on the results. Volunteers, rather than parole officers, also appear to have been used in recruitment for at least some of the sites, which could have reduced this limitation.

With regard to outcome data, the short follow-up of this study was another serious limitation. Given the time constraints involved in the project and attempts to improve/maximize the follow-up through some retrospective examinations of outcome and the inclusion of multiple measures of outcome, the follow-up seems reasonable. The current base rate of $25 \%$ failure also seems reasonable, although not ideal. The use of retrospective analyses may have introduced another selection bias in the sample, given that participating parolees were having some success since they were still in the community and retrospective analyses were bound to indicate such success. However, the inclusion of multiple measures of outcome was intended to be a more sensitive measure than simply using returns to custody. This could have potentially offset any selection bias from the use of retrospective data because even some of those "successful" offenders still on parole had previous problems included as measures of outcomes in this study. Informed consent forms used in this study also allowed for access to outcome data for offenders in the future, so an extended follow-up period is possible for future research. Of course, another limitation of even extended follow-ups is the very nature of desistance, and the difficulties surrounding its measurement given that one is measuring the absence of an event. Also relevant are the limitations of official data in detecting all actual criminal activity (or breaches of conditions, etc., in this study). This issue of 
detection is not just a limitation of this study but is a hazard of all research examining offender desistance/persistence in criminal behaviour.

The possibility of changes in the caseloads of parole officers and the reassignment of parolees to different parole officers was another limitation of the outcome data of this study. In this study, the relationship with the parole officer they had at the beginning of this study was somewhat isolated in that retrospective examinations of outcome began at their first contact with this particular parole officer. The long-term influences of this relationship may have continued even after reassignment to another parole office so such an examination was justified. With the exception of parole officers handling others' caseloads when they were away, casework records did not seem to indicate extensive reassignment.

The use of relatively new scales, particularly the Creating Choices Principles Questionnaire, was also a limitation in that it was unknown whether these items would adequately assess the application of these principles to the parole relationship and whether the Questionnaire and subscale items fit together in a coherent and statistically significant manner. However, the creation of a new scale can also be seen as a positive area of the study, particularly since no one has tried to measure these principles in such a standardized manner before. Psychometric analyses demonstrated excellent internal consistency for the CCPQ for both male and female parolees and good internal consistency for parole officers, as well as a significant correlation between CCPQ and DRI-R total scores, indicating concurrent validity in measuring the quality of relationships. The non-significant relationship between the CCPQ and RSE may simply reflect the multi-faceted nature of the CCPQ, when compared to the primary focus of the 
RSE on self-esteem (a small part of the Creating Choices principles). The nonsignificant correlation between CCPQ and POP-ROQ scores may have reflected the small sample size of parole officers, and the poor psychometrics shown for the POP-ROQ with this small sample, rather than fundamental problems with the CCPQ. Possible refinement of the scale and subscales (e.g., modification or elimination of items with low item-total correlations for parolees) may improve the CCPQ scale and subscales for use in future research. The preliminary, descriptive nature of this research was both a limitation and a strength.

\section{Strengths and Conclusions}

Some of the greatest strengths of this study came from attempting to address the void in women offender community correctional research and the potential implications of findings in this area. The results indicated the principles of Creating Choices seemed to be applied, but failed to show gender differences in adherence. The association between these principles and offender outcomes for women and men were also nonsignificant in this study. However, this ambitious exploratory research has laid the foundation for future research in this area with larger sample sizes. Gender comparisons with longer follow-ups are possible given the extended timelines provided for in parolee informed consent forms. Results of future research have the potential to inform the growing body of research related to women offender corrections and gender differences in corrections, as well as emerging desistance research. This study was also designed as an evaluation of $\mathrm{CSC}$ practices in community corrections and to determine whether changes were needed in parole officer training or policies. The current results appear to support current practices in the generally positive relationship depicted in both parolee 
and parole officer responses. Previous research support for the outcomes associated with these practices casts these results in a positive light. Recommendations with regard to community correctional policies would support the continuation of the development of these positive relationships and the enhancement of conditions to improve relationships (e.g., allow proper time and attention for these to develop), as one consideration when determining frequency of contact.

Further follow-ups for this sample and further research with larger samples may provide stronger direct empirical support for Creating Choices principles than has been demonstrated in previous research, particularly relating to women offenders. No other research has attempted to evaluate Creating Choices and community corrections in this quantitative way. Research on desistance factors has also rarely included women and mixed-gender research often included women as a minority or afterthought without examining gender differences. The intent of the current study in its explicit focus on gender differences made the study relatively unique and should make the results of continued research in this area practically useful. Unlike the current study, a great deal of women offender research, especially qualitative, has not involved direct comparisons with male offenders. While qualitative research is more common in women offender research, the quantitative nature of this research facilitated easy comparisons with male offenders and the possible use of a larger sample size, which may increase generalizability in future continuation and interpretation of this research.

While the current results were non-significant, the stage has been set for continued research in this underdeveloped area, establishing a strong focus on gender responsivity and the possibility of practical recommendations for community corrections. 
This future research can benefit from continued use of the new measures developed for this study. They have shown promise through their psychometric properties, and may be improved through refinement based on the psychometric analyses of the current study. The greatest strength of this study rests in its exploratory nature, the development of new measures and a research design that seems promising in its use for future research. Improvements based on lessons learned from the current study could inform areas of correctional research and practice that have been overlooked in the past. 


\section{References}

Andrews, D. A. (1980). Some experimental investigations of the principles of differential association through deliberate manipulations of the structure of service systems. American Sociological Review, 45, 448-462.

Andrews, D. A. (2001). Principles of effective correctional programs. In L. L. Motiuk \& R. C. Serin (Eds), Compendium 2000 on effective correctional treatment (pp. 917). Ottawa: Research Branch, Correctional Service Canada.

Andrews, D. A., Bonta, J., \& Wormith, J. S. (2006). The recent past and near future of risk and/or need assessment. Crime \& Delinquency, 52(1), 7-27.

Andrews, D. A., \& Dowden, C. (2005). Managing correctional treatment for reduced recidivism: A meta-analytic review of programme intensity. Legal and Criminological Psychology, 10, 173-187.

Andrews, D. A., \& Dowden, C. (2007). The risk-need-responsivity model of assessment and human service in prevention and corrections: Crime-prevention jurisprudence. Canadian Journal of Criminology and Criminal Justice, 49(4), 439-464.

Banyard, V. L., \& LaPlant, L. E. (2002). Exploring links between childhood maltreatment and empowerment. Journal of Community Psychology, 30(6), 687707.

Benda, B. B. (2005). Gender differences in life-course theory of recidivism: A survival analysis. International Journal of Offender Therapy and Comparative Criminology, 49(3), 325-342. 
Bottos, S. (2007). Personality and motives in the pathogenesis of substance abuse in offenders. Unpublished master's thesis, Carleton University, Ottawa, Ontario, Canada.

Bowers Andrews, A., Guadalupe, J. L., \& Bolden, E. (2003). Faith, hope, and mutual support: Paths to empowerment as perceived by women in poverty. Journal of Social Work Research and Evaluation, 4(1), 5-18.

Bresler, L., \& Lewis, D. K. (1983). Black and white women prisoners: Differences in family ties and their programmatic implications. The Prison Journal, 63(2), 116123.

Burnett, R., \& Maruna, S. (2004). So 'prison works,' does it? The criminal careers of 130 men released from prison under Home Secretary, Michael Howard. Howard Journal, 43(4), 390-404.

Burnett, R., \& McNeill, F. (2005). The place of the officer-offender relationship in assisting offenders to desist from crime. Journal of Community and Criminal Justice, 52(3), 221-242.

Cluley, E. (2004). Applying the findings of the Liverpool Desistance Study in probation practice: Views from the front-line 1. Journal of Community and Criminal Justice, 51(3), 233-236.

Cooper, M. L., Russell, M., Skinner, J. B., \& Windle, M. (1992). Development and validation of a three-dimensional measure of drinking motives. Psychological Assessment, 4(2), 123-132. 
Court, D. (2004). Applying the findings of the Liverpool Desistance Study in probation practice: Views from the front-line 2. Journal of Community and Criminal Justice, 51(3), 237-240.

Covington, S. S. (1998). Women in prison: Approaches in the treatment of our most invisible population. Women \& Therapy, 21(1), 141-155.

Crawford Shearer, N. B. (2004). Relationships of contextual and relational factors to health empowerment in women. Research and Theory for Nursing Practice: An International Journal, 18(4), 357-370.

Crivelli Kovach, A., Becker, J., \& Worley, H. (2004). The impact of community health workers on the self-determination, self-sufficiency, and decision-making ability of low-income women and mothers of young children. Journal of Community Psychology, 32(3), 343-356.

De Li, S., \& Layton MacKenzie, D. (2003). The gendered effects of adult social bonds on the criminal activities of probationers. Criminal Justice Review, 28(2), 278298.

Deguara, R. (2004). Utilizing a strengths perspective in parole supervision with women. Forum on Corrections Research, 16(1), 50.

Delveaux, K., Blanchette, K., \& Wickett, J. (2005). Employment needs, interests, and programming for women offenders (Research Report No. R-166). Ottawa: Correctional Service Canada.

Dembo, R. (1972). Orientation and activities of the parole officer. Criminology, 10, 193-215. 
Dowden, C., \& Andrews, D. A. (1999). What works for female offenders: A metaanalytic review. Crime \& Delinquency, 45(4), 438-452.

Dowden, C., \& Andrews, D. A. (2004). The importance of staff practice in delivering effective correctional treatment: A meta-analytic review of core correctional practice. International Journal of Offender Therapy and Comparative Criminology, 48(2), 203-214.

Expert Committee. (2006). Moving Forward with Women's Corrections: The Expert Committee Review of the Correctional Service of Canada's Ten-Year Status Report on Women's Corrections 1996-2006. Retrieved June 4, 2007, from http://www.csc-scc.gc.ca/text/prgrm/fsw/wos29/wos29_e.shtml

Falkin, G. P., \& Strauss, S. M. (2003). Social supporters and drug use enablers: A dilemma for women in recovery. Addictive Behaviors, 28, 141-155.

Farrall, S., \& Maruna, S. (2004). Desistance-focused criminal justice policy research: Introduction to a special issue on desistance from crime and public policy. Howard Journal, 43(4), 358-367.

French, S. \& Gendreau, P. (2003). Safe and Humane Corrections Through Effective Treatment (Research Report No. R-139). Ottawa: Correctional Service Canada.

Gadd, D., \& Farrall, S. (2004). Criminal careers, desistance and subjectivity: Interpreting men's narratives of change. Theoretical Criminology, 8(2), 123-156.

Geiger, B., \& Fischer, M. (2005). Naming oneself criminal: Gender difference in offenders' identity negotiation. International Journal of Offender Therapy and Comparative Criminology, 49(2), 194-209. 
Giordano, P. C., Cernkovich, S. A., \& Holland, D. D. (2003). Changes in friendship relations over the life course: Implications for desistance from crime. Criminology, 41(2), 293-327.

Giordano, P. C., Cernkovich, S. A., \& Rudolph, J. L. (2002). Gender, crime, and desistance: Toward a theory of cognitive transformation. American Journal of Sociology, 107(4), 990-1064.

Gottschall, S., \& Serin, R. C. (2008). Women Offender Desistance: An Examination of Protective Factors and a Pathways Model of Substance Abuse. Unpublished manuscript, Carleton University, Ottawa, Canada.

Greenberger, E., Chen, C., Dmitrieva, J., \& Farruggia, S. P. (2003). Item-wording and the dimensionality of the Rosenberg Self-Esteem Scale: Do they matter? Personality and Individual Differences, 35(6), 1241-1254.

Haggård, U., Gumpert, C. H., \& Grann, M. (2001). Against all odds: A qualitative follow-up study of high-risk violent offenders who were not reconvicted. Journal of Interpersonal Violence, 16(10), 1048-1065.

Hannah-Moffat, K. (2000). Prisons that empower: Neo-liberal governance in Canadian women's prisons. British Journal of Criminology, 40, 510-531.

Harm, N. J., \& Phillips, S. D. (2001). You can’t go home again: Women and criminal recidivism. Journal of Offender Rehabilitation, 32(3), 3-21.

Hechanova, M. R. M., Alampay, R. B. A., \& Franco, E. P. (2006). Psychological empowerment, job satisfaction and performance among Filipino service workers. Asian Journal of Social Psychology, 9, 72-78. 
Hser, Y.-I., Huang, D., Teruya, C., \& Anglin, M. D. (2003). Gender comparisons of drug abuse treatment outcomes and predictors. Drug and Alcohol Dependence, $72,255-264$.

Hume, L. (2004). A gender-specific substance abuse program for federally-sentenced women. Forum on Corrections Research, 16(1), 40-41.

Hussong, A. M., Curran, P. J., Moffitt, T. E., Caspi, A., \& Carrig, M. M. (2004).

Substance abuse hinders desistance in young adults' antisocial behavior. Development and Psychopathology, 16, 1029-1046.

Katz, R. S. (2000). Explaining girls' and womens' crime and desistance in the context of their victimization experiences: A developmental test of revised strain theory and the life course perspective. Violence Against Women, 6(6), 633-660.

Klockars, C. B. (1972). A theory of probation supervision. Journal of Criminal Law, Criminology and Police Science, 63(4), 550-557.

Koberg, C. S., Boss, R. W., Senjem, J. C., \& Goodman, E. A. (1999). Antecedents and outcomes of empowerment: Empirical evidence from the health care industry. Group \& Organization Management, 24(1), 71-91.

Koons, B. A., Burrow, J. D., Morash, M., \& Bynum, T. (1997). Expert and offender perceptions of program elements linked to successful outcomes for incarcerated women. Crime \& Delinquency, 43(4), 512-532.

Kosterman, R., Hawkins, J. D., Abbott, R. D., Hill, K. G., Herrenkohl, T. I., \& Catalano, R. F. (2005). Measures of positive adult behavior and their relationship to crime and substance use. Prevention Science, 6(1), 21-33. 
Krienert, J. L., \& Fleisher, M. S. (2001). Economic rehabilitation: A reassessment of the link between employment and crime. Corrections Management Quarterly, 5(4), 53-63.

Laub, J. H., Nagin, D. S., \& Sampson, R. J. (1998). Trajectories of change in criminal offending: Good marriages and the desistance process. American Sociological Review, 63(2), 225-238.

Law, M. A. (2004). Federally sentenced women in the community: Dynamic risk predictors. Forum on Corrections Research, 16(1), 18-20.

Leverentz, A. M. (2006). The love of a good man? Romantic relationships as a source of support or hindrance for female ex-offenders. Journal of Research in Crime and Delinquency, 43(4), 459-488.

Liang, B., Tracy, A. J., Taylor, C. A., \& Williams, L. M. (2002). Mentoring college-age women: A relational approach. American Journal of Community Psychology, $30(2), 271-288$.

Maruna, S. (2004). Desistance from crime and explanatory style: A new direction in the psychology of reform. Journal of Contemporary Criminal Justice, 20(2), 184200.

Maruna, S., \& LeBel, T. P. (2003). Welcome home? Examining the "reentry court" concept from a strengths-based perspective. Western Criminology Review, 4(2), $91-107$.

Maruna, S., LeBel, T. P., Mitchell, N., \& Naples, M. (2004). Pygmalion in the reintegration process: Desistance from crime through the looking glass. Psychology, Crime \& Law, 10(3), 271-281. 
Maruna, S., Porter, L., \& Carvalho, I. (2004). The Liverpool Desistance Study and probation practice: Opening the dialogue. Journal of Community and Criminal Justice, 51(3), 221-232.

McLean, R. L., Robarge, J., \& Sherman, S. G. (2006). Release from jail: Moment of crisis or window of opportunity for female detainees? Journal of Urban Health: Bulletin of the New York Academy of Medicine, 83(3), 382-393.

McNeill, F. (2004). Supporting desistance in probation practice: A response to Maruna, Porter and Carvalho. Journal of Community and Criminal Justice, 51(3), 241247.

Motiuk, L. (1997). Classification for correctional programming: The Offender Intake Assessment (OIA) process. Forum on Corrections Research, 9(1), 18-22.

Mullins, C. W., \& Wright, R. (2003). Gender, social networks, and residential burglary. Criminology, 41(3), 813-838.

Nafekh, M., \& Motiuk, L. L. (2002). The Statistical Information on RecidivismRevised 1 (SIR-R1) Scale: A Psychometric Examination. (Research Report No. R-126). Ottawa: Correctional Service Canada.

Naser, R. L., \& La Vigne, N. G. (2006). Family support in the prisoner reentry process: Expectations and realities. Journal of Offender Rehabilitation, 43(1), 93-106.

O'Brien, P. (2001a). Claiming our soul: An Empowerment group for African-American women in prison. Journal of Progressive Human Services, 12(1), 35-52.

O'Brien, P. (2001b). Just like baking a cake: Women describe the necessary ingredients for successful reentry after incarceration. Families in Society: The Journal of Contemporary Human Services, 82(3), 287-295. 
O'Brien, P., \& Bates, R. (2005). Women's post-release experiences in the U.S.:

Recidivism and re-entry. International Journal of Prisoner Health, 1(2-4), 207221.

Office of the Correctional Investigator. (2006). Annual Report of the Office of the Correctional Investigator 2005-2006. Retrieved June 15, 2007, from http://www.oci-bec.gc.ca/reports/AR200506_download_e.asp

Paparozzi, M. A., \& Gendreau, P. (2005). An intensive supervision program that worked: Service delivery, professional orientation, and organizational supportiveness. Prison Journal, 85(4), 445-466.

Parsons, M. L., \& Warner-Robbins, C. (2002). Factors that support women's successful transition to the community following jail/prison. Health Care for Women International, 23, 6-18.

Patrick, A., \& Spence Laschinger, H. K. (2006). The effect of structural empowerment and perceived organizational support on middle level nurse managers' role satisfaction. Journal of Nursing Management, 14, 13-22.

Peersen, M., Sigurdsson, J. F., Gudjonsson, G. H., \& Gretarsson, S. J. (2004). Predicting re-offending: A 5-year prospective study of Icelandic prison inmates. Psychology, Crime \& Law, 10(2), 197-204.

Pelissier, B., \& Jones, N. (2005). A review of gender differences among substance abusers. Crime \& Delinquency, 5l(3), 343-372.

Reisig, M. D., Holtfreter, K., \& Morash, M. (2002). Social capital among women offenders: Examining the distribution of social networks and resources. Journal of Contemporary Criminal Justice, 18(2), 167-187. 
Rex, S. (1999). Desistance from offending: Experiences of probation. Howard Journal, 38(4), 366-383.

Richie, B. E. (2001). Challenges incarcerated women face as they return to their communities: Findings from life history interviews. Crime \& Delinquency, 47(3), 368-389.

Robins, R. W., Hendin, H. M., \& Trzesniewski, K. H. (2001). Measuring global selfesteem: Construct validation of a single-item measure and the Rosenberg SelfEsteem Scale. Personality and Social Psychology Bulletin, 27(2), 151-161.

Rosenberg, M. (1965). Society and the adolescent self-image. Princeton, New Jersey: Princeton University Press.

Roth, D., \& Crane-Ross, D. (2002). Impact of services, met needs, and service empowerment on consumer outcomes. Mental Health Services Research, 4(1), 43-56.

Sampson, R. J., \& Laub, J. H. (1990). Crime and deviance over the life course: The salience of adult social bonds. American Sociological Review, 55(5), 609-627.

Seiter, R. P. (2002). Prisoner reentry and the role of parole officers. Federal Probation, $66(3), 50-54$.

Seiter, R. P., \& West, A. D. (2003). Supervision styles in probation and parole: An analysis of activities. Journal of Offender Rehabilitation, 38(2), 57-75.

Sinclair, R. L., \& Boe, R. (2002). Canadian federal women offender profiles: Trends from 1981 to 2002 (Research Report No. R-131). Ottawa: Correctional Service Canada. 
Skeem, J., Eno Louden, J., Camp, J., \& Polaschek, D. (in press). Assessing relationship quality in mandated community treatment: Blending care with control. Psychological Assessment.

Sommers, I., Baskin, D. R., \& Fagan, J. (1994). Getting out of the life: crime desistance by female street offenders. Deviant Behaviour: An Interdisciplinary Journal, 15, 125-149.

Stouthamer-Loeber, M., Wei, E., Loeber, R., \& Masten, A. S. (2004). Desistance from persistent serious delinquency in the transition to adulthood. Development and Psychopathology, 16, 897-918.

Straussner, S. L. A., \& Phillips, N. K. (2005). The role of empathy in work with women offenders. International Journal of Prisoner Health, 1(2-4), 255-262.

Task Force on Federally Sentenced Women (1990). Creating choices: Report of the Task Force on Federally Sentenced Women. Ottawa, Ontario: Ministry of the Solicitor General Canada.

Trotter, C. (1990). Probation can work: A research study using volunteers. Australian Social Work, 43(2), 13-18.

Trotter, C. (1996). The impact of different supervision practices in community corrections: Cause for optimism. Australian and New Zealand Journal of Criminology, 29 (1), 29-46.

Uggen, C., \& Kruttschnitt, C. (1998). Crime in the breaking: Gender differences in desistance. Law \& Society Review, 32(2), 339-366. 
van Wormer, K., \& Kaplan, L. E. (2006). Results of a national survey of wardens in women's prisons: The case for gender specific treatment. Women $\&$ Therapy, $29(1 / 2), 133-151$.

Verbrugge, P., Nunes, K., Johnson, S., \& Taylor, K. (2002). Predictors of revocation of conditional release among substance abusing women offenders (Research Report No. R-133). Ottawa: Correctional Service Canada.

Ward, L. C., Kersh, B. C., \& Shanks, D. (1997). Psychometric assessment of motives for using cocaine in men with substance use disorders. Psychological Reports, $80,189-190$.

Wilson, M. K., \& Anderson, S. C. (1997). Empowering female offenders: Removing barriers to community-based practice. Affilia, 12, 342-358.

Worell, J. (2001). Feminist interventions: Accountability beyond symptom reduction. Psychology of Women Quarterly, 25, 335-343.

Wormith, J. S., Althouse, R., Simpson, M., Reitzel, L. R., Fagan, T. J., \& Morgan, R. D. (2007). The rehabilitation and reintegration of offenders: The current landscape and some future directions for correctional psychology. Criminal Justice and Behavior, 34(7), 879-892.

Yoder, J. D., Schleicher, T. L., \& McDonald, T. W. (1998). Empowering token women leaders: The importance of organizationally legitimated credibility. Psychology of Women Quarterly, 22, 209-222. 
Community Corrections 87

Appendix A: List of Items from Subscales of Modified Dual Role Relationship Inventory - Revised (DRI-R) 


\section{DRI-R Items}

\section{Caring/Fairness}

\begin{tabular}{|c|c|}
\hline Parole Officer Items & Parolee Items \\
\hline I care about clients as people. & My PO cares about me as a person. \\
\hline $\begin{array}{l}\text { I explain what clients are supposed to do } \\
\text { and why it would be good to do it. }\end{array}$ & $\begin{array}{l}\text { My PO explains what I am supposed to do } \\
\text { and why it would be good to do it. }\end{array}$ \\
\hline $\begin{array}{l}\text { I try very hard to do the right thing by my } \\
\text { clients. }\end{array}$ & $\begin{array}{l}\text { My PO tries very hard to do the right thing } \\
\text { by me. }\end{array}$ \\
\hline $\begin{array}{l}\text { When clients have trouble doing what is } \\
\text { required, I talk with them and listen to what } \\
\text { they have to say. }\end{array}$ & $\begin{array}{l}\text { When I have trouble doing what I am } \\
\text { supposed to do, my PO talks with me and } \\
\text { listens to what I have to say. }\end{array}$ \\
\hline $\begin{array}{l}\text { If a client breaks the rules, I calmly explain } \\
\text { what has to be done and why. }\end{array}$ & $\begin{array}{l}\text { If I break the rules, my PO calmly explains } \\
\text { what has to be done and why. }\end{array}$ \\
\hline $\begin{array}{l}\text { I am enthusiastic and optimistic with my } \\
\text { clients. }\end{array}$ & $\begin{array}{l}\text { My PO is enthusiastic and optimistic with } \\
\text { me. }\end{array}$ \\
\hline $\begin{array}{l}\text { I encourage my clients to work together } \\
\text { with me. }\end{array}$ & $\begin{array}{l}\text { My PO encourages me to work together } \\
\text { with him/her. }\end{array}$ \\
\hline $\begin{array}{l}\text { I make allowances for my client's situation } \\
\text { when deciding what he/she needs to do. }\end{array}$ & $\begin{array}{l}\text { My PO really considers my situation when } \\
\text { deciding what I'm supposed to do. }\end{array}$ \\
\hline $\begin{array}{l}\text { I am really devoted to helping my clients } \\
\text { overcome their problems. }\end{array}$ & $\begin{array}{l}\text { My PO seems devoted to helping me } \\
\text { overcome my problems. }\end{array}$ \\
\hline $\begin{array}{l}\text { I am interested in how my clients feel } \\
\text { about what they are required to do. }\end{array}$ & $\begin{array}{l}\text { My PO is interested in how I feel about } \\
\text { what I have to do. }\end{array}$ \\
\hline
\end{tabular}




\begin{tabular}{|c|c|}
\hline $\begin{array}{l}\text { I am very warm and friendly with my } \\
\text { clients. }\end{array}$ & My PO is warm and friendly with me. \\
\hline I treat my clients fairly. & My PO treats me fairly. \\
\hline $\begin{array}{l}\text { I am always clear with my client about } \\
\text { what he/she is required to do. }\end{array}$ & $\begin{array}{l}\text { My PO is clear with me about what I have } \\
\text { to do. }\end{array}$ \\
\hline $\begin{array}{l}\text { If a client breaks the rules, I disapprove in a } \\
\text { way that is not at all angry. }\end{array}$ & $\begin{array}{l}\text { If I break the rules, my PO disapproves in a } \\
\text { way that is not at all angry. }\end{array}$ \\
\hline $\begin{array}{l}\text { I really care about my client's personal } \\
\text { concerns. }\end{array}$ & $\begin{array}{l}\text { My PO really cares about my personal } \\
\text { concerns. }\end{array}$ \\
\hline $\begin{array}{l}\text { I praise a client for the good things he/she } \\
\text { does. }\end{array}$ & My PO praises me for the good things I do. \\
\hline $\begin{array}{l}\text { When a client is going in a bad direction, I } \\
\text { talk with him/her before taking serious } \\
\text { action. }\end{array}$ & $\begin{array}{l}\text { If I'm going in a bad direction, my PO will } \\
\text { talk with me before doing anything drastic. }\end{array}$ \\
\hline I genuinely want to help my clients. & I know that my PO truly wants to help me. \\
\hline I consider a client's views. & My PO considers my views. \\
\hline $\begin{array}{l}\text { I give a client plenty of room to voice } \\
\text { complaints. }\end{array}$ & $\begin{array}{l}\text { My PO gives me enough of a chance to say } \\
\text { what I want to say. }\end{array}$ \\
\hline $\begin{array}{l}\text { I can take the time required to really } \\
\text { understand a client. }\end{array}$ & $\begin{array}{l}\text { My PO takes enough time to understand } \\
\text { me. }\end{array}$ \\
\hline I take all of a client's needs into account. & My PO takes my needs into account. \\
\hline $\begin{array}{l}\text { I show a client respect in absolutely all of } \\
\text { my dealings with him/her. }\end{array}$ & $\begin{array}{l}\text { My PO shows me respect in absolutely all } \\
\text { his/her dealings with me. }\end{array}$ \\
\hline
\end{tabular}




\begin{tabular}{|l|l|}
\hline $\begin{array}{l}\text { I treat each client like everyone else on my } \\
\text { caseload. }\end{array}$ & $\begin{array}{l}\text { I bet that my PO treats me like everyone } \\
\text { else on his/her caseload. }\end{array}$
\end{tabular}

\begin{tabular}{|c|c|}
\hline Trust & \\
\hline Parole Officer Items & Parolee Items \\
\hline $\begin{array}{l}\text { Clients feel free to discuss with me the } \\
\text { things that worry them. }\end{array}$ & $\begin{array}{l}\text { I feel free to discuss with my PO the things } \\
\text { that worry me. }\end{array}$ \\
\hline $\begin{array}{l}\text { Clients seem to feel safe enough to be open } \\
\text { and honest with me. }\end{array}$ & $\begin{array}{l}\text { I feel safe enough to be open and honest } \\
\text { with my PO. }\end{array}$ \\
\hline I trust my clients to be honest with me. & My PO trusts me to be honest with him $/$ her. \\
\hline I know that I can trust clients. & My PO knows that he/she can trust me. \\
\hline $\begin{array}{l}\text { My clients seem to feel I am someone they } \\
\text { can trust. }\end{array}$ & My PO is someone that I trust. \\
\hline $\begin{array}{l}\text { My clients keep some important things to } \\
\text { themselves and won't tell me about them } \\
\text { [reverse coded]. }\end{array}$ & $\begin{array}{l}\text { I keep some important things to myself and } \\
\text { won't tell my PO [reverse coded]. }\end{array}$ \\
\hline
\end{tabular}

\section{Toughness}

\begin{tabular}{|l|l|}
\hline Parole Officer Items & Parolee Items \\
\hline I talk down to my clients [reverse coded]. & My PO talks down to me [reverse coded]. \\
\hline $\begin{array}{l}\text { If my clients do something wrong, I put } \\
\text { them down to prevent the problem from } \\
\text { happening again [reverse coded]. }\end{array}$ & My PO puts me down when I've done \\
\hline
\end{tabular}




\begin{tabular}{|l|l|}
\hline $\begin{array}{l}\text { My clients seem worried that I am looking } \\
\text { to punish them [reverse coded]. }\end{array}$ & $\begin{array}{l}\text { I feel that my PO is looking to punish me } \\
\text { [reverse coded]. }\end{array}$ \\
\hline $\begin{array}{l}\text { Given my job, I make tough demands of a } \\
\text { client [reverse coded]. }\end{array}$ & My PO makes unreasonable demands of \\
me [reverse coded].
\end{tabular}


Community Corrections 92

Appendix B: List of Items from Modified Parole Officer Punishment and Reintegrative Orientation Questionnaire (POP-ROQ) 


\section{POP-ROQ Items}

\begin{tabular}{|c|c|}
\hline Punishment Orientation & Reintegrative Orientation \\
\hline $\begin{array}{l}\text { In response to psychological pressures, and } \\
\text { social circumstances, the individual } \\
\text { offender violates the law because he } \\
\text { decides to do so. }\end{array}$ & $\begin{array}{l}\text { Biological, psychological, and social } \\
\text { factors predispose and reinforce law- } \\
\text { violation behaviour, which the offender is } \\
\text { unable to control. }\end{array}$ \\
\hline $\begin{array}{l}\text { The causes of crime are located in factors } \\
\text { internal to the offender. }\end{array}$ & $\begin{array}{l}\text { The causes of crime are to be found in } \\
\text { factors external to the offender. }\end{array}$ \\
\hline $\begin{array}{l}\text { During the initial contacts with the parolee } \\
\text { it is important to review this past behaviour } \\
\text { pattern, assess his/her feelings about them, } \\
\text { in order to appraise him/her of where } \\
\text { he/she stands and the alternatives available } \\
\text { to him/her. }\end{array}$ & $\begin{array}{l}\text { Initial contacts with the parolee should be } \\
\text { concerned with expression of confidence in } \\
\text { his adjustment potential, and trying to } \\
\text { establish some realistic concrete goals. } \\
\text { There should be a minimum necessary } \\
\text { review of subject's past behaviour. }\end{array}$ \\
\hline $\begin{array}{l}\text { During the supervision period, as such } \\
\text { situations arise, it is useful to point to } \\
\text { examples of wrong decision, bad } \\
\text { judgement, and selfish behaviour, and note } \\
\text { to the subject their possible comparison to } \\
\text { past behaviour. }\end{array}$ & $\begin{array}{l}\text { Provide encouragement for the subject to } \\
\text { attain reasonable goals, and enable him/her } \\
\text { to develop strength in handling } \\
\text { himself/herself. Reference to past } \\
\text { behaviour should be avoided, unless } \\
\text { suggested by the subject. }\end{array}$ \\
\hline $\begin{array}{l}\text { Continually keep in mind that every } \\
\text { parolee is a potential violator, and relate to } \\
\text { him in such a manner that violation does }\end{array}$ & $\begin{array}{l}\text { Concentrate your efforts to help the subject } \\
\text { develop work and adjustment skills, and } \\
\text { increase his/her confidence to guide his life }\end{array}$ \\
\hline
\end{tabular}




\begin{tabular}{|c|c|}
\hline $\begin{array}{l}\text { not decrease your confidence in help } \\
\text { others. }\end{array}$ & $\begin{array}{l}\text { in an acceptable manner. Concern for } \\
\text { potential violation, while present, should be } \\
\text { minimal. }\end{array}$ \\
\hline $\begin{array}{l}\text { It is more probable that more parolees will } \\
\text { revert to crime than will be rehabilitated } \\
\text { within a ten year period following their } \\
\text { release from the institution. }\end{array}$ & $\begin{array}{l}\text { The degree of parolee reversion to crime } \\
\text { will depend, in part, on the effort you make } \\
\text { on their behalf, assisting in their } \\
\text { reintegration into the community. }\end{array}$ \\
\hline $\begin{array}{l}\text { Classification into criminal types reflects } \\
\text { underlying behaviour tendencies which } \\
\text { should be taken into account in supervising } \\
\text { the parolee. }\end{array}$ & $\begin{array}{l}\text { Crime type is a label, which does not } \\
\text { reflect the diversity of personalities and } \\
\text { problems causing any particular criminal } \\
\text { act or anti-social behaviour. }\end{array}$ \\
\hline $\begin{array}{l}\text { Dealing with the parolee as a type } \\
\text { offense(s) individual prevents over- } \\
\text { involvement with him/her as an individual } \\
\text { and enables the parole officer to be more } \\
\text { effective in relating to him/her. }\end{array}$ & $\begin{array}{l}\text { It is important to get involved in a case, } \\
\text { since the more we do, the more we see the } \\
\text { parolee as an individual with needs we can } \\
\text { minister. }\end{array}$ \\
\hline $\begin{array}{l}\text { It is best to approach the supervision } \\
\text { relationship by asking: What problems has } \\
\text { the subject's past behaviour pattern } \\
\text { indicated needs remediation? }\end{array}$ & $\begin{array}{l}\text { It is best to approach the supervision } \\
\text { relationship by asking: What are the } \\
\text { subject's needs to which we can provide } \\
\text { assistance? }\end{array}$ \\
\hline $\begin{array}{l}\text { Narcotic addicts are very difficult to deal } \\
\text { with, since so many appear to enjoy this } \\
\text { form of deviance. }\end{array}$ & $\begin{array}{l}\text { While a problem, present methods of } \\
\text { treatment are varyingly helpful. The task is } \\
\text { to determine which program fits the }\end{array}$ \\
\hline
\end{tabular}




\begin{tabular}{|c|c|}
\hline & $\begin{array}{l}\text { parolee's needs - i.e., tailor a progrm for } \\
\text { him/her. }\end{array}$ \\
\hline $\begin{array}{l}\text { Concentrate on ensuring that the } \\
\text { community is secure from his/her possible } \\
\text { reversion to criminally or anti-social } \\
\text { behaviour. }\end{array}$ & $\begin{array}{l}\text { Aim to rehabilitate the offender so that the } \\
\text { task of community protection will be } \\
\text { unnecessary. }\end{array}$ \\
\hline $\begin{array}{l}\text { It is most important that proper control be } \\
\text { maintained on one's caseload by home and } \\
\text { employment visits, and frequent other case } \\
\text { contacts. }\end{array}$ & $\begin{array}{l}\text { Prime focus should be on providing needed } \\
\text { client services, such as counseling, job, } \\
\text { psychological referrals and assistance, with } \\
\text { a minimum of control measures. }\end{array}$ \\
\hline $\begin{array}{l}\text { We must recognize that offender difficulty } \\
\text { in community acceptance is a protection } \\
\text { measure to assure reintegreation of those } \\
\text { who behaviour is that of a good citizen. }\end{array}$ & $\begin{array}{l}\text { Public rejection of the parolee is self- } \\
\text { defeating, reflecting a lack of } \\
\text { understanding of human behaviour, a } \\
\text { posture which only embitters the offender } \\
\text { and confirms his/her sense of alienation. }\end{array}$ \\
\hline $\begin{array}{l}\text { The parolee's parole experience should, at } \\
\text { best, give him/her experience in leading a } \\
\text { law abiding life, so that upon discharge he } \\
\text { can continue his good adjustment while } \\
\text { unsupervised. }\end{array}$ & $\begin{array}{l}\text { The parole experience should seek to give } \\
\text { the parolee insight and understanding into } \\
\text { himself/herself and his/her behaviour, as } \\
\text { both he/she and his/her parole officer work } \\
\text { through the various adjustment situations } \\
\text { encountered by the parolee. }\end{array}$ \\
\hline $\begin{array}{l}\text { In requiring parole officer approval for } \\
\text { decisions, the Rules and Regulations aid in }\end{array}$ & $\begin{array}{l}\text { Requiring parole officer approval for } \\
\text { decisions, the Rules provide a valuable }\end{array}$ \\
\hline
\end{tabular}




\begin{tabular}{|c|c|}
\hline $\begin{array}{l}\text { preventing the parolee from engaging in } \\
\text { actions harmful to himself/herself and/or } \\
\text { others. }\end{array}$ & $\begin{array}{l}\text { educational tool by which officer and } \\
\text { parolee can discuss the merits and } \\
\text { consequences of important decisions. }\end{array}$ \\
\hline $\begin{array}{l}\text { Parole Rules and Regulations are to be } \\
\text { looked upon as minimal acceptable } \\
\text { standards of behaviour for continued } \\
\text { presence in the community. }\end{array}$ & $\begin{array}{l}\text { Parole Rules and Regulations are to be } \\
\text { used as a constructive aid, giving the } \\
\text { parolee experience in conducting his/her } \\
\text { life in an orderly, acceptable manner, } \\
\text { though they may in part reflect a middle- } \\
\text { class morality to which he/she does not } \\
\text { ascribe. }\end{array}$ \\
\hline $\begin{array}{l}\text { Parole Rules and Regulations provide the } \\
\text { guidelines by which to evaluate the } \\
\text { parolee's intention to be a useful citizen. }\end{array}$ & $\begin{array}{l}\text { Parole Rules and Regulations provide } \\
\text { guidelines by which to evaluate the } \\
\text { parolee's ability to fulfill important } \\
\text { responsibilities to himself/herself and } \\
\text { others. }\end{array}$ \\
\hline $\begin{array}{l}\text { It is helpful to establish a curfew, since, if } \\
\text { followed, it prevents the parolee from } \\
\text { being at places at hours where law and } \\
\text { parole violation is probable. }\end{array}$ & $\begin{array}{l}\text { Curfew placing is an additional restriction, } \\
\text { indicating to the parolee a lack of } \\
\text { confidence in his/her ability to guide } \\
\text { his/her affairs. Establish a curfew only if } \\
\text { the parolee's behaviour indicates a need for } \\
\text { same. }\end{array}$ \\
\hline $\begin{array}{l}\text { The Rules and Regulations of Parolee's } \\
\text { contract to the community, and violation of }\end{array}$ & $\begin{array}{l}\text { While a contract, violation of parole Rules } \\
\text { and Regulations should be interpreted in }\end{array}$ \\
\hline
\end{tabular}




\begin{tabular}{|c|c|}
\hline $\begin{array}{l}\text { them should be responded to by } \\
\text { incarceration. }\end{array}$ & $\begin{array}{l}\text { terms of the subject concerned. Violation, } \\
\text { in cases where we have a choice, may or } \\
\text { may not be indicated depending on the } \\
\text { parolee's intent and needs. }\end{array}$ \\
\hline $\begin{array}{l}\text { Parole Rules and Regulations should be } \\
\text { enforced uniformly, without variation in } \\
\text { individual cases, or else parolees may come } \\
\text { to resent what they consider favouritism on } \\
\text { your part. }\end{array}$ & $\begin{array}{l}\text { While a possible first reaction, resentment } \\
\text { of favouritism soon gives way to respect } \\
\text { for the interpretive judgement of the parole } \\
\text { officer. }\end{array}$ \\
\hline $\begin{array}{l}\text { Irregardless of the parolee's statements, } \\
\text { his/her conformance to the Rules and } \\
\text { Regulations of Parole is the best indicator } \\
\text { of his/her parole performance and } \\
\text { prognosis. }\end{array}$ & $\begin{array}{l}\text { The parolee's statements and declarations } \\
\text { of intent are important in evaluating his/her } \\
\text { ability to live up to his/her parole } \\
\text { responsibilities. }\end{array}$ \\
\hline $\begin{array}{l}\text { Unless you receive advance information as } \\
\text { to why he/she cannot report, it is wise to } \\
\text { request warrant issuance if a parolee fails } \\
\text { to make two successive office reports, even } \\
\text { though his/her adjustment until that point } \\
\text { has been good. }\end{array}$ & $\begin{array}{l}\text { Given good parole adjustment, and two } \\
\text { successive report failures, request for } \\
\text { warrant issuance should await further } \\
\text { investigation to determine the need for } \\
\text { such action. }\end{array}$ \\
\hline $\begin{array}{l}\text { The parole officer's work should not } \\
\text { extend beyond the period for which he/she } \\
\text { is paid by the State. }\end{array}$ & $\begin{array}{l}\text { The parole officer should attempt to deal } \\
\text { with parolee's needs and provide needed } \\
\text { services, even if work on those needs }\end{array}$ \\
\hline
\end{tabular}




\begin{tabular}{|c|c|}
\hline & $\begin{array}{l}\text { exceeds the amount of time for which } \\
\text { he/she is compensated. }\end{array}$ \\
\hline $\begin{array}{l}\text { Adjustments can and should be made to } \\
\text { fulfill paperwork and parolee needs within } \\
\text { the framework of the established pay } \\
\text { period. }\end{array}$ & $\begin{array}{l}\text { The present pay period is not sufficient to } \\
\text { satisfy paperwork and parolee service } \\
\text { requirements. }\end{array}$ \\
\hline
\end{tabular}


Appendix C: Creating Choices Principles Questionnaire (CCPQ) Items 


\section{CCPQ Items}

\begin{tabular}{|c|c|}
\hline Empowerment & \\
\hline Parole Officer Items & Parolee Items \\
\hline $\begin{array}{l}\text { I talk a lot with my clients about their } \\
\text { problems/weaknesses and things they need } \\
\text { to avoid [reverse coded]. }\end{array}$ & $\begin{array}{l}\text { My PO talks a lot about my } \\
\text { problems/weaknesses and things I need to } \\
\text { avoid [reverse coded]. }\end{array}$ \\
\hline $\begin{array}{l}\text { I consider my clients' strengths when } \\
\text { making plans for their time in the } \\
\text { community. }\end{array}$ & $\begin{array}{l}\text { My PO considers my strengths when } \\
\text { making plans for my time in the } \\
\text { community. }\end{array}$ \\
\hline $\begin{array}{l}\text { I help my clients feel good about } \\
\text { themselves. }\end{array}$ & My PO helps me feel good about myself. \\
\hline $\begin{array}{l}\text { I help my clients to feel they are in control } \\
\text { of their lives in a positive way. }\end{array}$ & $\begin{array}{l}\text { My PO helps me feel like I can control my } \\
\text { life in a positive way. }\end{array}$ \\
\hline $\begin{array}{l}\text { I encourage my clients to take steps to } \\
\text { improve their lives. }\end{array}$ & $\begin{array}{l}\text { My PO encourages me to do things to } \\
\text { improve my life. }\end{array}$ \\
\hline
\end{tabular}

\begin{tabular}{|l|l|}
\hline Meaningful and Responsible Choices & \\
\hline Parole Officer Items & Parolee Items \\
\hline $\begin{array}{l}\text { I make plans for my clients' time under } \\
\text { supervision on my own, without their input } \\
\text { [reverse coded]. }\end{array}$ & $\begin{array}{l}\text { My PO makes plans for my time under } \\
\text { supervision all on his own, without me } \\
\text { [reverse coded]. }\end{array}$ \\
\hline $\begin{array}{l}\text { I give my clients the opportunity to } \\
\text { participate in decisions about their }\end{array}$ & My PO gives me the opportunity to \\
\hline
\end{tabular}




\begin{tabular}{|l|l|}
\hline supervision. & supervision. \\
\hline I encourage my clients to participate in & My PO encourages me to participate in \\
needs they may have (for example, & needs I may have (for example, \\
drug/alcohol problems, employment needs, & drug/alcohol problems, employment needs, \\
etc.). & etc.). \\
\hline $\begin{array}{l}\text { I give my clients the opportunity to choose } \\
\text { programs or services available to help them }\end{array}$ & My PO gives me the opportunity to choose \\
during their supervision. & during my supervision. \\
\hline I help my clients prepare for tasks and & My PO helps me to prepare for tasks and \\
decisions that they may face in the future. & decisions I may face in the future. \\
\hline
\end{tabular}

\begin{tabular}{|l|l|}
\hline Respect and Dignity & \\
\hline Parole Officer Items & Parolee Items \\
\hline I treat my clients with respect. & My PO treats me with respect. \\
\hline $\begin{array}{l}\text { I respect my clients' cultures and spiritual } \\
\text { whether they understand them is not my }\end{array}$ & My PO respects my culture and my \\
\hline I expect my clients to follow the rules; & My PO expects me to follow rules that \\
\hline $\begin{array}{l}\text { I treat my clients fairly. } \\
\text { I listen to what my clients have to say and }\end{array}$ & My PO listens to whe and doesn't explain \\
\hline respect their opinions. & respects my opinions. \\
\hline
\end{tabular}




\begin{tabular}{|c|c|}
\hline Supportive Environment & \\
\hline Parole Officer Items & Parolee Items \\
\hline $\begin{array}{l}\text { I help my clients deal with problems or } \\
\text { situations that arise during their } \\
\text { supervision. }\end{array}$ & $\begin{array}{l}\text { My PO helps me deal with problems or } \\
\text { situations that come up during my } \\
\text { supervision. }\end{array}$ \\
\hline I give my clients useful advice. & My PO gives me useful advice. \\
\hline I support my clients and encourage them. & My PO supports me and encourages me. \\
\hline $\begin{array}{l}\text { I have strict expectations for my clients and } \\
\text { apply consequences if they are not met, } \\
\text { regardless of the reason [reverse coded]. }\end{array}$ & $\begin{array}{l}\text { My PO has very strict expectations and } \\
\text { harsh penalties if these expectations are not } \\
\text { met, regardless of why they were not met } \\
\text { [reverse coded]. }\end{array}$ \\
\hline $\begin{array}{l}\text { I promote my clients' interests when } \\
\text { dealing with other agencies and groups (for } \\
\text { example, employment agencies, } \\
\text { government assistance, etc.). }\end{array}$ & $\begin{array}{l}\text { My PO promotes my interests when } \\
\text { dealing with other agencies and groups (for } \\
\text { example, employment agencies, } \\
\text { government assistance, etc.). }\end{array}$ \\
\hline
\end{tabular}

\begin{tabular}{|l|l|}
\hline Shared Responsibility & \\
\hline Parole Officer Items & Parolee Items \\
\hline I emphasize to my clients the importance of & My PO emphasizes the importance of \\
programs and services available in the & programs and services available in the \\
community. & community. \\
\hline I encourage my clients to find groups and & My PO encourages me to find groups and \\
\hline
\end{tabular}




\begin{tabular}{|c|c|}
\hline $\begin{array}{l}\text { services in the community that can help } \\
\text { them once their supervision has ended. }\end{array}$ & $\begin{array}{l}\text { services in the community that can help me } \\
\text { once my supervision has ended. }\end{array}$ \\
\hline $\begin{array}{l}\text { I refer my clients to community } \\
\text { groups/services that may benefit them. }\end{array}$ & $\begin{array}{l}\text { My PO has referred me to community } \\
\text { groups/services that may help me. }\end{array}$ \\
\hline $\begin{array}{l}\text { I don't think community groups and } \\
\text { programs help my caseload [reverse } \\
\text { coded]. }\end{array}$ & $\begin{array}{l}\text { I bet my PO does not think community } \\
\text { groups and programs are helpful [reverse } \\
\text { coded]. }\end{array}$ \\
\hline $\begin{array}{l}\text { I build partnerships with other groups and } \\
\text { agencies in the community to help with the } \\
\text { reintegration of my clients. }\end{array}$ & $\begin{array}{l}\text { My PO works with other groups and } \\
\text { agencies in the community to help me } \\
\text { during my time under supervision in the } \\
\text { community. }\end{array}$ \\
\hline
\end{tabular}


Appendix D: Rosenberg Self-Esteem Scale (RSE) 


\section{Rosenberg Self-Esteem Scale}

Please assign each item a number from 1 to 5 ( $1=$ not very true of me; $5=$ very true of me).

On the whole, I am satisfied with myself.

At times I think I am no good at all [reverse-coded].

I feel that I have a number of good qualities.

I am able to do things as well as most other people.

I feel I do not have much to be proud of [reverse-coded].

I certainly feel useless at times [reverse-coded].

I feel that I'm a person of worth, or at least on an equal plane with others.

I wish I could have more respect for myself [reverse-coded].

All in all, I am inclined to feel that I am a failure [reverse-coded].

I take a positive attitude toward myself. 
Community Corrections 106

Appendix E: Modified Drinking Motives Questionnaire (DMQ) 
Drinking Motives Questionnaire

Each of the following questions assesses the reasons for the most recent alcohol/drug use in your past. The questions are not asking when you have used alcohol or drugs. Please recall the most recent occasion you used alcohol or drugs in answering the questions regarding why you used. Please assign each question a number from 1 to 4 ( $1=$ never/almost never; 4=always/almost always).

When you drank and/or used drugs was it...

As a way to celebrate? (Social)

To relax? (Coping)

Because you like the feeling? (Enhancement)

Because it is what most of your friends do when you get together? (Social)

To forget your worries? (Coping)

Because it's exciting? (Enhancement)

To be sociable? (Social)

Because you feel more self-confident or sure of yourself? (Coping)

To get high? (Enhancement)

Because it is customary on special occasions? (Social)

Because it helps you when you feel depressed or nervous? (Coping)

Because it's fun? (Enhancement)

Because it makes a social gathering more enjoyable? (Social)

To cheer up when you're in a bad mood? (Coping)

Because it makes you feel good? (Enhancement) 
Appendix F: Covariate Questionnaires 


\section{Parolee Questionnaire}

Please provide the following information to the best of your ability:

Age: Gender:

Most serious offence that resulted in your current sentence:

Race/Ethnicity (please circle one of the following categories):

$\begin{array}{ll}\text { Arab/West Asian } & \text { Asiatic } \\ \text { African/African Canadian } & \text { Caucasian } \\ \text { East Indian } & \text { Hispanic } \\ \text { Innu } & \text { Inuit } \\ \text { Metis } & \text { Aboriginal } \\ \text { Chinese } & \text { Filipino } \\ \text { Japanese } & \text { Korean } \\ \text { Latin American } & \text { South Asian } \\ \text { South East Asian } & \text { Other (please specify: }\end{array}$

Estimated annual income (please circle one of the following categories):

Less than $\$ 10,000$

$$
\$ 10,000 \text { to } \$ 20,000
$$

$\$ 20,000$ to $\$ 30,000$

$\$ 30,000$ to $\$ 50,000$

$$
\$ 50,000 \text { to } \$ 100,000
$$

Over $\$ 100,000$

Marital status (please circle one of the following categories):

$\begin{array}{lll}\text { Married } & \text { Common Law } & \text { Separated } \\ \text { Single } & \text { Widower } & \text { Divorced }\end{array}$

Other (please specify:

Employment status (please circle one of the following categories): 


$\begin{array}{ll}\text { Employed full-time } & \text { Employed part-time } \\ \text { Attending school } & \text { Volunteering }\end{array}$

Other (please specify:

Total number of friends, family or others (not including your parole officer) who provide you with regular help/support while under supervision: 


\section{Parole Officer Questionnaire}

Please provide the following information to the best of your ability:

Age:

Gender:

Number of years of experience:

Number of female parolees under your supervision:

Number of male parolees under your supervision: 
Community Corrections 112

Appendix G: Informed Consent for Parole Officers and Parolees 


\section{Parole Officer Informed Consent}

The purpose of an informed consent form is to ensure that you understand the purpose of the study and the nature of your involvement. The informed consent form must provide sufficient information such that you have the opportunity to determine whether you wish to participate in the study.

Research title: Offender Desistance: An Examination of Creating Choices as it is Applied in Community Corrections

Purpose: We are interested in the nature of the parolee-parole officer relationship. We will be assessing the quality of that relationship and looking at its connection with parolee outcomes. We will be making comparisons between the answers of male and female parolees and comparing the connection between the parolee-parole officer relationship and outcome for both women and men.

Task requirements and duration: Should you choose to participate in the study, you will be asked to participate in a 45 to 60 minute session to answer questions about your interactions with parolees, and your personal characteristics, such as supervision experience. Upon completion of these questionnaires, you will be asked to return these to the researcher through pre-paid postage. You will also be asked to discuss the study with all parolees under your supervision, regardless of type of conditional release, and invite their voluntary participation. Given that some parolees under your supervision may have a low frequency of contact with you, we ask that you contact them outside of your usual contact schedule to ensure they have the opportunity to participate. We also ask that you record who you asked, when you asked them, and who accepted a questionnaire package, 
so we can track response rates. This information would also be forwarded to the researcher through pre-paid postage.

Potential risk/discomfort: Due to the fact that you will be asked questions about these relationships, there is a possibility that you will experience some degree of anxiety, pain or embarrassment. Please be reminded that your participation is entirely voluntary, that you may choose not to answer any question, and that you may withdraw from the study at any time without penalty if any part of it makes you feel uncomfortable. If participating in this study upsets you in any way you may wish to speak to someone. It is recommended that you contact a local distress centre if you continue to feel distressed. The following phone numbers may be of help:

New Westminster Participants: Greater Coquitlam Crisis \& Information Line (604-5402221)

Moncton Participants: The Helpline (506-859-4357)

Edmonton Participants: The Support Network Distress Line (1-800-232-7288 or 780482-HELP)

Toronto Participants: Distress Line (416-408-4357) Hamilton Participants: Distress Centre of Hamilton (905-525-8611) Ville Marie Participants: Comite prevention suicide Temiscaminque (1-800-567-6407) Anonymity/confidentiality: Your answers will be confidential and will only be seen by the researchers. Your answers will be linked to the outcomes of offenders under your supervision, as reflected in their files. This assessment will only be used by the researchers for the purposes of this study and will not be used for an evaluation of your performance or affect your employment in any way. You will not be identified in any 
reports or publications that result from this research. There are, however, limits to confidentiality and should you indicate that you might harm yourself or someone else, this must be reported. This also applies if you report committing undisclosed crimes against children for which you have not been convicted.

Research personnel: The following people are involved in this research project and may be contacted for further information: Shannon Gottschall (Principal Investigator; 613520-2600, ext. 1595; sgottsch@connect.carleton.ca), Dr. Ralph Serin (Supervisor; 613520-2600, ext. 1557; ralph_serin@carleton.ca). Should you have any ethical concerns about this study then please contact Dr. Avi Parush (Chair of the Carleton University Ethics Committee for Psychological Research; Avi_Parush@,carleton.ca; 613-520-2600, ext. 6026). Should you have any other concerns about this study then please contact Dr. Anne Bowker (Chair of the Department of Psychology; psychchair@carleton.ca; 613520-2600, ext. 2648).

\section{Signatures}

I have read the above form and understand the conditions of my participation. My participation in this study is voluntary, and if for any reason, at any time, I wish to leave the experiment I may do so without having to give an explanation. Furthermore, I am also aware that the data gathered in this study are confidential with respect to my personal identity. My signature indicates that I agree to participate in this study. Participant's Name:

Participant's Signature:

Researcher's Name: 
Researcher's Signature:

Date: 


\section{Parolee Informed Consent}

The purpose of an informed consent form is to ensure that you understand the purpose of the study and the nature of your involvement. The informed consent form must provide sufficient information such that you have the opportunity to determine whether you wish to participate in the study.

Research title: Offender Desistance: An Examination of Creating Choices as it is Applied in Community Corrections

Purpose: We are interested in the nature of the parolee-parole officer relationship. We will be assessing the quality of that relationship and looking at its connection with parolee outcomes. We will be making comparisons between the answers of male and female parolees and comparing the connection between the parolee-parole officer relationship and outcome for both women and men.

Task requirements and duration: Should you choose to participate in the study, you will be asked to participate in a 45 to 60 minute session to answer questions about your interactions with your parole officer. You will also be asked to complete questionnaires related to self-esteem, reasons for substance abuse, and your personal characteristics, such as marital and employment status. Upon completion of these questionnaires, you will be asked to return these to the researcher through pre-paid postage.

Potential risk/discomfort: Due to the fact that you will be asked questions about these relationships, there is a possibility that you will experience some degree of anxiety, pain or embarrassment. Please be reminded that your participation is entirely voluntary, that you may choose not to answer any question, and that you may withdraw from the study at any time without penalty if any part of it makes you feel uncomfortable. If participating 
in this study upsets you in any way you may wish to speak to someone. It is recommended that you contact a local distress centre if you continue to feel distressed. The following phone numbers may be of help: New Westminster Participants: Greater Coquitlam Crisis \& Information Line (604-5402221)

Moncton Participants: The Helpline (506-859-4357)

Edmonton Participants: The Support Network Distress Line (1-800-232-7288 or 780482-HELP)

Toronto Participants: Distress Line (416-408-4357)

Hamilton Participants: Distress Centre of Hamilton (905-525-8611)

Ville Marie Participants: Comite prevention suicide Temiscaminque (1-800-567-6407) Anonymity/confidentiality: Despite being asked by your parole officer to participate, your answers will be confidential and will only be seen by the researchers. Your answers will be linked to your individual outcome, as reflected in your offender files. Your responses will only be used by the researchers for the purposes of this study and will not affect your supervision status. You will not be identified in any reports or publications that result from this research. There are, however, limits to confidentiality and should you indicate that you might harm yourself or someone else, this must be reported. This also applies if you report committing undisclosed crimes against children for which you have not been convicted.

Offender Management System (OMS) data/Follow-up: Your consent allows us to analyze information collected from you by the Correctional Service of Canada, such as program information and risk/need assessments, and stored in the Offender Management 
System (OMS) database. This information would include parole suspensions/revocations, new sentences, disciplinary interviews, and urinalysis results. Your consent permits us to conduct this follow-up research up to July 15, 2010.

Research personnel: The following people are involved in this research project and may be contacted for further information: Shannon Gottschall (Principal Investigator; 613520-2600, ext. 1595; sgottsch@connect.carleton.ca), Dr. Ralph Serin (Supervisor; 613520-2600, ext. 1557; ralph_serin@carleton.ca). Should you have any ethical concerns about this study then please contact Dr. Avi Parush (Chair of the Carleton University Ethics Committee for Psychological Research; Avi_Parush@carleton.ca; 613-520-2600, ext. 6026). Should you have any other concerns about this study then please contact Dr. Anne Bowker (Chair of the Department of Psychology; psychchair@)carleton.ca; 613520-2600, ext. 2648).

\section{Signatures}

I have read the above form and understand the conditions of my participation. My participation in this study is voluntary, and if for any reason, at any time, I wish to leave the experiment I may do so without having to give an explanation. Furthermore, I am also aware that the data gathered in this study are confidential with respect to my personal identity. My signature indicates that I agree to participate in this study.

Participant's Name:

Participant's Signature: Researcher's Name: 
Researcher's Signature:

Date: 
Community Corrections 121

Appendix H: Parolee/Parole Officer Debriefing 


\section{Offender Desistance: An Examination of Creating Choices as it is Applied in Community Corrections Debriefing}

\section{What are we trying to learn in this research?}

The purpose of this study is to understand the relationships between parole officers and parolees, as well as whether this relationship is linked to offender success in the community. More specifically, we are interested in the quality of the parolee-parole officer relationship in terms of the principles of Creating Choices which have essentially formed the basis of women offender federal correctional policies. It is also our intention to explore whether the parolee-parole officer relationship differs between male and female parolees, and whether this relationship differs between male and female parolees in terms of their community success.

\section{What are our hypotheses/predictions?}

Based on the Correctional Service of Canada policy it is expected that staff interactions with female parolees will reflect the Creating Choices principles more than interactions with male parolees. Based on previous research, it is also predicted that following these principles in interactions between parolees and parole officers will be related to improved outcomes generally, and it is further hypothesized that the link between the relationship and outcome will be stronger for women parolees.

Why is this important to researchers and the general public?

It is hoped that this study will give us a better understanding of the importance of the parolee-parole officer relationship in enhancing release to the community. In particular, this study tests whether the Creating Choices principles are being followed, and whether 
the principles are related to outcome. Such understanding could increase the success of parolees, improving their individual futures, and improve public safety generally.

\section{Where can I learn more?}

If you are interested in research on the parolee-parole officer relationship, see Maruna, S., Porter, L., \& Carvalho, I. (2004). The Liverpool Desistance Study and probation practice: Opening the dialogue. Journal of Community and Criminal Justice, 51(3), 221232, or see Paparozzi, M. A., \& Gendreau, P. (2005). An intensive supervision program that worked: Service delivery, professional orientation, and organizational supportiveness. Prison Journal, 85(4), 445-466. If you are interested in the principles of Creating Choices, see Task Force on Federally Sentenced Women (1990). Creating Choices: Report of the Task Force on Federally Sentenced Women. Ottawa, Ontario: Ministry of the Solicitor General Canada.

\section{If you have questions...}

In the event that you have any concerns about this study, or anything you wish to discuss further please use these contacts. For questions or concerns about the study, you may contact Shannon Gottschall (Principal Investigator; 613-520-2600, ext. 1595; sgottsch@connect.carleton.ca), or Dr. Ralph Serin (Supervisor; 613-520-2600, ext. 1557; ralph_serin@carleton.ca). Should you have any ethical concerns about this study then please contact Dr. Avi Parush (Chair of the Carleton University Ethics Committee for Psychological Research; Avi_Parush@carleton.ca; 613-520-2600, ext. 6026). Should you have any other concerns about this study then please contact Dr. Anne Bowker (Chair of the Department of Psychology; psychchair@carleton.ca; 613-520-2600, ext. 2648). 


\section{If you are feeling distressed...}

If participating in this study has upset you in any way you may wish to speak to someone. It is recommended that you contact a local distress centre if you continue to feel distressed. The following phone numbers may be of help:

New Westminster Participants: Greater Coquitlam Crisis \& Information Line (604-5402221)

Moncton Participants: The Helpline (506-859-4357)

Edmonton Participants: The Support Network Distress Line (1-800-232-7288 or 780482-HELP)

Toronto Participants: Distress Line (416-408-4357)

Hamilton Participants: Distress Centre of Hamilton (905-525-8611)

Ville Marie Participants: Comite prevention suicide Temiscaminque (1-800-567-6407)

\section{Thank you for participating!}


Community Corrections 125

Appendix I: DRI-R Psychometrics 
Table I1. Item-total correlations for DRI-R for parolees.

Scale item

$n$

33

My PO cares about me as a person.

My PO explains what I am supposed to do and why it 33 would be good to do it.

My PO tries very hard to do the right thing by me.

33

When I have trouble doing what I am supposed to do, 33 my PO talks with me and listens to what I have to say.

If I break the rules, my PO calmly explains what has to be done and why.

My PO is enthusiastic and optimistic with me.

33

My PO encourages me to work together with him/her.

My PO really considers my situation when deciding what I'm supposed to do.

My PO seems devoted to helping me overcome my problems.

My PO is interested in how I feel about what I have to do.

My PO is warm and friendly with me.

My PO treats me fairly.

My PO is clear with me about what I have to do.

If I break the rules, my PO disapproves in a way that is not at all angry.

My PO really cares about my personal concerns.

My PO praises me for the good things I do.
33

0.60

$0.63 \quad .000$

$0.52 \quad .002$

0.73

.000

33

0.72

33

0.84

.000

33

0.79 .000

33

0.85

.000

33

0.65

.000

$0.72 \quad .000$

$0.66 \quad .000$

$0.25 \quad .168$

33

0.83

.000

33

0.63

.000 
If I'm going in a bad direction, my PO will talk with 33

0.62

.000

me before doing anything drastic.

I know that my PO truly wants to help me.

33

0.83

.000

My PO considers my views.

33

0.80

.000

My PO gives me enough of a chance to say what I

33

0.81

.000

want to say.

My PO takes enough time to understand me.

33

0.77

.000

My PO takes my needs into account.

33

0.79

.000

My PO shows me respect in absolutely all his/her

33

0.82

.000

dealings with me.

I bet that my PO treats me like everyone else on

33

0.41

.019

his/her caseload.

I feel free to discuss with my PO the things that worry 33 me.

$0.69 \quad .000$

I feel safe enough to be open and honest with my PO. 33

$0.70 \quad .000$

My PO trusts me to be honest with him/her.

33

$0.74 \quad .000$

My PO knows that he/she can trust me.

0.61

.000

My PO is someone that I trust.

33

$0.83 \quad .000$

I keep some important things to myself and won't tell 33

0.56

.001 my PO (reverse-coded).

My PO puts me down when I've done something wrong (reverse-coded).

My PO makes unreasonable demands of me (reversecoded).

My PO talks down to me (reverse-coded).

I feel that my PO is looking to punish me (reverse-

33

0.76

.000 coded). 
Community Corrections 128

My PO expects me to do all the work alone and 
Table I2. Item-total correlations for DRI-R for male parolees.

\begin{tabular}{|c|c|c|c|}
\hline Scale item & $n$ & $r$ & $p$ \\
\hline My PO cares about me as a person. & 24 & 0.25 & .242 \\
\hline $\begin{array}{l}\text { My PO explains what I am supposed to do and why it } \\
\text { would be good to do it. }\end{array}$ & 24 & 0.47 & .020 \\
\hline My PO tries very hard to do the right thing by me. & 24 & 0.73 & .000 \\
\hline $\begin{array}{l}\text { When I have trouble doing what I am supposed to do, } \\
\text { my PO talks with me and listens to what I have to say. }\end{array}$ & 24 & 0.55 & .006 \\
\hline $\begin{array}{l}\text { If I break the rules, my PO calmly explains what has } \\
\text { to be done and why. }\end{array}$ & 24 & 0.53 & .008 \\
\hline My PO is enthusiastic and optimistic with me. & 24 & 0.62 & .001 \\
\hline My PO encourages me to work together with him/her. & 24 & 0.74 & .000 \\
\hline $\begin{array}{l}\text { My PO really considers my situation when deciding } \\
\text { what I'm supposed to do. }\end{array}$ & 24 & 0.84 & .000 \\
\hline $\begin{array}{l}\text { My PO seems devoted to helping me overcome my } \\
\text { problems. }\end{array}$ & 24 & 0.90 & .000 \\
\hline $\begin{array}{l}\text { My PO is interested in how I feel about what I have to } \\
\text { do. }\end{array}$ & 24 & 0.83 & .000 \\
\hline My PO is warm and friendly with me. & 24 & 0.73 & .000 \\
\hline My PO treats me fairly. & 24 & 0.76 & .000 \\
\hline My PO is clear with me about what I have to do. & 24 & 0.74 & .000 \\
\hline $\begin{array}{l}\text { If I break the rules, my PO disapproves in a way that } \\
\text { is not at all angry. }\end{array}$ & 24 & 0.02 & .914 \\
\hline My PO really cares about my personal concerns. & 24 & 0.87 & .000 \\
\hline My PO praises me for the good things I do. & 24 & 0.64 & .001 \\
\hline $\begin{array}{l}\text { If I'm going in a bad direction, my PO will talk with } \\
\text { me before doing anything drastic. }\end{array}$ & 24 & 0.50 & .014 \\
\hline
\end{tabular}


I know that my PO truly wants to help me.

My PO gives me enough of a chance to say what I

My PO takes enough time to understand me.

My PO takes my needs into account.

My PO shows me respect in absolutely all his/her

I bet that my PO treats me like everyone else on me.

I feel safe enough to be open and honest with my PO. $\quad 24$

$0.71 \quad .000$

My PO trusts me to be honest with him/her.

My PO knows that he/she can trust me.

My PO is someone that I trust.

I keep some important things to myself and won't tell

My PO makes unreasonable demands of me (reversecoded).

My PO talks down to me (reverse-coded). coded). 
Table 13. Item-total correlations for DRI-R for female parolees.

\begin{tabular}{|c|c|c|c|}
\hline Scale item & $n$ & $r$ & $p$ \\
\hline My PO cares about me as a person. & 9 & 0.83 & .006 \\
\hline $\begin{array}{l}\text { My PO explains what I am supposed to do and why it } \\
\text { would be good to do it. }\end{array}$ & 9 & 0.67 & .050 \\
\hline My PO tries very hard to do the right thing by me. & 9 & 0.78 & .014 \\
\hline $\begin{array}{l}\text { When I have trouble doing what I am supposed to do, } \\
\text { my PO talks with me and listens to what I have to say. }\end{array}$ & 9 & 0.82 & .007 \\
\hline $\begin{array}{l}\text { If I break the rules, my PO calmly explains what has } \\
\text { to be done and why. }\end{array}$ & 9 & 0.88 & .002 \\
\hline My PO is enthusiastic and optimistic with me. & 9 & 0.80 & .010 \\
\hline My PO encourages me to work together with him/her. & 9 & 0.74 & .022 \\
\hline $\begin{array}{l}\text { My PO really considers my situation when deciding } \\
\text { what I'm supposed to do. }\end{array}$ & 9 & 0.86 & .003 \\
\hline $\begin{array}{l}\text { My PO seems devoted to helping me overcome my } \\
\text { problems. }\end{array}$ & 9 & 0.65 & .059 \\
\hline $\begin{array}{l}\text { My PO is interested in how I feel about what I have to } \\
\text { do. }\end{array}$ & 9 & 0.91 & .001 \\
\hline My PO is warm and friendly with me. & 9 & 0.50 & .173 \\
\hline My PO treats me fairly. & 9 & 0.78 & .014 \\
\hline My PO is clear with me about what I have to do. & 9 & 0.64 & .065 \\
\hline $\begin{array}{l}\text { If I break the rules, my PO disapproves in a way that } \\
\text { is not at all angry. }\end{array}$ & 9 & 0.92 & .001 \\
\hline My PO really cares about my personal concerns. & 9 & 0.84 & .005 \\
\hline My PO praises me for the good things I do. & 9 & 0.74 & .022 \\
\hline $\begin{array}{l}\text { If I'm going in a bad direction, my PO will talk with } \\
\text { me before doing anything drastic. }\end{array}$ & 9 & 0.91 & .001 \\
\hline
\end{tabular}


I know that my PO truly wants to help me.

My PO considers my views.

My PO gives me enough of a chance to say what I want to say.

My PO takes enough time to understand me.

My PO takes my needs into account.

My PO shows me respect in absolutely all his/her dealings with me.

I bet that my PO treats me like everyone else on me.

I feel safe enough to be open and honest with my PO. 9

My PO is someone that I trust.

I keep some important things to myself and won't tell

0.71 my PO (reverse-coded).

My PO puts me down when I've done something

My PO makes unreasonable demands of me (reverse- 9 coded).

My PO talks down to me (reverse-coded).

I feel that my PO is looking to punish me (reversecoded).

My PO expects me to do all the work alone and 
Table 14. Item-total correlations for DRI-R for parole officer interactions with male parolees.

\begin{tabular}{|c|c|c|c|}
\hline Scale item & $n$ & $r$ & $p$ \\
\hline I care about clients as people. & 9 & 0.59 & .098 \\
\hline $\begin{array}{l}\text { I explain what clients are supposed to do and why it } \\
\text { would be good to do it. }\end{array}$ & 9 & 0.66 & .056 \\
\hline I try very hard to do the right thing by my clients. & 9 & 0.37 & .322 \\
\hline $\begin{array}{l}\text { When clients have trouble doing what is required, I } \\
\text { talk with them and listen to what they have to say. }\end{array}$ & 9 & 0.54 & .131 \\
\hline $\begin{array}{l}\text { If a client breaks the rules, I calmly explain what has } \\
\text { to be done and why. }\end{array}$ & 9 & 0.33 & .384 \\
\hline I am enthusiastic and optimistic with my clients. & 9 & 0.49 & .185 \\
\hline I encourage my clients to work together with me. & 9 & 0.46 & .210 \\
\hline $\begin{array}{l}\text { I make allowances for my client's situation when } \\
\text { deciding what he/she needs to do. }\end{array}$ & 9 & 0.38 & .307 \\
\hline $\begin{array}{l}\text { I am really devoted to helping my clients overcome } \\
\text { their problems. }\end{array}$ & 9 & 0.38 & .307 \\
\hline $\begin{array}{l}\text { I am interested in how my clients feel about what they } \\
\text { are required to do. }\end{array}$ & 9 & 0.71 & .032 \\
\hline I am very warm and friendly with my clients. & 9 & 0.28 & .465 \\
\hline I treat my clients fairly. & 9 & 0.30 & .430 \\
\hline $\begin{array}{l}\text { I am always clear with my client about what he/she is } \\
\text { required to do. }\end{array}$ & 9 & 0.66 & .054 \\
\hline $\begin{array}{l}\text { If a client breaks the rules, I disapprove in a way that } \\
\text { is not at all angry. }\end{array}$ & 9 & 0.23 & .551 \\
\hline I really care about my client's personal concerns. & 9 & 0.54 & .133 \\
\hline
\end{tabular}


I praise a client for the good things he/she does.

$\begin{array}{lll}9 & 0.48 \quad .187\end{array}$

When a client is going in a bad direction, I talk with $\quad 9 \quad 0.34 \quad .376$ $\mathrm{him} /$ her before taking serious action.

$\begin{array}{llll}\text { I genuinely want to help my clients. } & 9 & 0.59 & .098\end{array}$

$\begin{array}{llll}\text { I consider a client's views. } & 9 & 0.77 & .015\end{array}$

$\begin{array}{llll}\text { I give a client plenty of room to voice complaints. } & 9 & 0.77 & .015\end{array}$

$\begin{array}{lllll}\text { I can take the time required to really understand a } & 9 & 0.77 & .015\end{array}$ client.

$\begin{array}{llll}\text { I take all of a client's needs into account. } & 9 & 0.69 & .040\end{array}$

$\begin{array}{llll}\text { I show a client respect in absolutely all of my dealings } & 9 & 0.45 & .224\end{array}$

with $\mathrm{him} / \mathrm{her}$.

$\begin{array}{llll}\text { I treat each client like everyone else on my caseload. } & 9 & 0.72 & .030\end{array}$

$\begin{array}{llll}\text { Clients feel free to discuss with me the things that } & 9 & 0.89 & .001\end{array}$ worry them.

$\begin{array}{llll}\text { Clients seem to feel safe enough to be open and honest } & 9 & 0.89 & .001\end{array}$ with me.

$\begin{array}{llll}\text { I trust my clients to be honest with me. } & 9 & 0.87 & .002\end{array}$

$\begin{array}{llll}\text { I know that I can trust clients. } & 9 & 0.60 & .090\end{array}$

$\begin{array}{llll}\text { My clients seem to feel I am someone they can trust. } \quad 9 & 9 & 0.91 & .001\end{array}$

$\begin{array}{llll}\text { My clients seem worried that I am looking to punish } & 9 & 0.90 & .001\end{array}$ them (reverse-coded).

$\begin{array}{llll}\text { If my clients do something wrong, I put them down to } & 9 & 0.52 & .153\end{array}$ prevent the problem from happening again (reversecoded).

$\begin{array}{lllll}\text { Given my job, I make tough demands of a client } & 9 & 0.64 & .063\end{array}$ (reverse-coded).

$\begin{array}{llll}\text { My clients keep some important things to themselves } & 9 & 0.47 & .202\end{array}$ and won't tell me about them (reverse-coded). 


\begin{tabular}{llll}
\hline I talk down to my clients (reverse-coded). & 9 & 0.45 & .224 \\
$\begin{array}{l}\text { I expect a client to do things independently, and don't } \\
\text { help him/her too much (reverse-coded). }\end{array}$ & 9 & -0.24 & .530 \\
\hline
\end{tabular}


Table I5. Item-total correlations for DRI-R for parole officer interactions with female parolees.

\begin{tabular}{|c|c|c|c|}
\hline Scale item & $n$ & $r$ & $p$ \\
\hline I care about clients as people. & 10 & 0.64 & .045 \\
\hline $\begin{array}{l}\text { I explain what clients are supposed to do and why it } \\
\text { would be good to do it. }\end{array}$ & 10 & 0.47 & .170 \\
\hline I try very hard to do the right thing by my clients. & 10 & 0.47 & .167 \\
\hline $\begin{array}{l}\text { When clients have trouble doing what is required, I } \\
\text { talk with them and listen to what they have to say. }\end{array}$ & 10 & 0.74 & .014 \\
\hline $\begin{array}{l}\text { If a client breaks the rules, I calmly explain what has } \\
\text { to be done and why. }\end{array}$ & 10 & 0.53 & .115 \\
\hline I am enthusiastic and optimistic with my clients. & 10 & 0.38 & .279 \\
\hline I encourage my clients to work together with me. & 10 & 0.39 & .262 \\
\hline $\begin{array}{l}\text { I make allowances for my client's situation when } \\
\text { deciding what he/she needs to do. }\end{array}$ & 10 & 0.45 & .193 \\
\hline $\begin{array}{l}\text { I am really devoted to helping my clients overcome } \\
\text { their problems. }\end{array}$ & 10 & 0.24 & .507 \\
\hline $\begin{array}{l}\text { I am interested in how my clients feel about what they } \\
\text { are required to do. }\end{array}$ & 10 & 0.84 & .003 \\
\hline I am very warm and friendly with my clients. & 10 & 0.35 & .319 \\
\hline I treat my clients fairly. & 10 & 0.48 & .156 \\
\hline $\begin{array}{l}\text { I am always clear with my client about what he/she is } \\
\text { required to do. }\end{array}$ & 10 & 0.76 & .011 \\
\hline $\begin{array}{l}\text { If a client breaks the rules, I disapprove in a way that } \\
\text { is not at all angry. }\end{array}$ & 10 & 0.29 & .421 \\
\hline I really care about my client's personal concerns. & 10 & 0.53 & .116 \\
\hline I praise a client for the good things he/she does. & 10 & 0.56 & .092 \\
\hline
\end{tabular}


When a client is going in a bad direction, I talk with

10

0.45

.187

$\mathrm{him} /$ her before taking serious action.

I genuinely want to help my clients.

10

0.54

.111

I consider a client's views.

10

0.85

.002

I give a client plenty of room to voice complaints.

10

0.87

.001

I can take the time required to really understand a

10

0.88

.001

client.

I take all of a client's needs into account.

10

0.78

.008

I show a client respect in absolutely all of my dealings 10

0.65

.044

with $\mathrm{him} / \mathrm{her}$.

I treat each client like everyone else on my caseload.

10

0.80

.005

Clients feel free to discuss with me the things that

10

0.85

.002

worry them.

Clients seem to feel safe enough to be open and honest 10

0.73

.016 with me.

I trust my clients to be honest with me.

10

0.87

.001

I know that I can trust clients.

10

0.69

.028

My clients seem to feel I am someone they can trust.

10

0.88

.001

My clients seem worried that I am looking to punish

10

0.87

.001

them (reverse-coded).

If my clients do something wrong, I put them down to 10

0.64

.045 prevent the problem from happening again (reversecoded).

Given my job, I make tough demands of a client (reverse-coded).

My clients keep some important things to themselves and won't tell me about them (reverse-coded).

I talk down to my clients (reverse-coded). 
Community Corrections 138

\begin{tabular}{l}
\hline $\begin{array}{l}\text { I expect a client to do things independently, and don't } \\
\text { help him/her too much (reverse-coded). }\end{array}$ \\
\hline
\end{tabular}


Community Corrections 139

Appendix J: POP-ROQ Psychometrics 
Table J1. Item-total correlations for POP-ROQ for parole officer interactions with male parolees.

\begin{tabular}{|c|c|c|c|}
\hline Scale item & $n$ & $r$ & $p$ \\
\hline Item 1 & 8 & 0.70 & .053 \\
\hline Item 2 & 8 & 0.58 & .132 \\
\hline Item 3 & 8 & 0.64 & .090 \\
\hline Item 4 & 8 & -0.08 & .854 \\
\hline Item 5 & 8 & 0.60 & .114 \\
\hline Item 6 & 8 & 0.40 & .331 \\
\hline Item 7 & 8 & 0.28 & .501 \\
\hline Item 8 & 8 & 0.36 & .376 \\
\hline Item 9 & 8 & 0.72 & .046 \\
\hline Item 10 & 8 & 0.69 & .058 \\
\hline Item 11 & 8 & 0.37 & .368 \\
\hline Item 12 & 8 & 0.29 & .490 \\
\hline Item 13 & 8 & 0.42 & .297 \\
\hline Item 14 & 8 & 0.68 & .064 \\
\hline Item 15 & 8 & 0.53 & .173 \\
\hline Item 16 & 8 & 0.70 & .053 \\
\hline Item 17 & 8 & -0.20 & .636 \\
\hline Item 18 & 8 & 0.32 & .447 \\
\hline Item 19 & 8 & -0.09 & .841 \\
\hline Item 20 & 8 & -0.19 & .646 \\
\hline
\end{tabular}


Community Corrections 141

Item 21

$\begin{array}{lll}8 & -0.51 & .200\end{array}$

Item 22

8

$-0.16 \quad .697$

Item 23

8

$0.03 \quad .953$

Item 24

8

0.89

.003 
Table J2. Item-total correlations for POP-ROQ for parole officer interactions with female parolees.

\begin{tabular}{|c|c|c|c|}
\hline Scale item & $n$ & $r$ & $p$ \\
\hline Item 1 & 9 & 0.69 & .040 \\
\hline Item 2 & 9 & 0.56 & .121 \\
\hline Item 3 & 9 & 0.53 & .141 \\
\hline Item 4 & 9 & -0.07 & .862 \\
\hline Item 5 & 9 & 0.62 & .077 \\
\hline Item 6 & 9 & 0.37 & .330 \\
\hline Item 7 & 9 & 0.24 & .528 \\
\hline Item 8 & 9 & 0.35 & .351 \\
\hline Item 9 & 9 & 0.72 & .029 \\
\hline Item 10 & 9 & 0.70 & .035 \\
\hline Item 11 & 9 & 0.37 & .329 \\
\hline Item 12 & 9 & 0.29 & .453 \\
\hline Item 13 & 9 & 0.41 & .277 \\
\hline Item 14 & 9 & 0.68 & .046 \\
\hline Item 15 & 9 & 0.54 & .135 \\
\hline Item 16 & 9 & 0.69 & .040 \\
\hline Item 17 & 9 & -0.20 & .600 \\
\hline Item 18 & 9 & 0.29 & .443 \\
\hline Item 19 & 9 & -0.10 & .805 \\
\hline Item 20 & 9 & -0.21 & .588 \\
\hline
\end{tabular}


Community Corrections 143

Item 21

$\begin{array}{llll}9 & -0.51 & .163\end{array}$

Item 22

$\begin{array}{lll}9 & -0.19 & .626\end{array}$

Item 23

9

$0.04 \quad .916$

Item 24

9

$0.87 \quad .002$ 
Community Corrections 144

Appendix K: CCPQ Psychometrics 
Table K1. Item-total correlations for CCPQ for parolees.

\begin{tabular}{|c|c|c|c|}
\hline Scale item & $n$ & $r$ & $p$ \\
\hline $\begin{array}{l}\text { My PO considers my strengths when making plans for } \\
\text { my time in the community. }\end{array}$ & 32 & 0.77 & .000 \\
\hline My PO helps me feel good about myself. & 32 & 0.84 & .000 \\
\hline $\begin{array}{l}\text { My PO helps me feel like I can control my life in a } \\
\text { positive way. }\end{array}$ & 32 & 0.86 & .000 \\
\hline $\begin{array}{l}\text { My PO encourages me to find groups and services in } \\
\text { the community that can help me once my supervision } \\
\text { has ended. }\end{array}$ & 32 & 0.41 & .019 \\
\hline $\begin{array}{l}\text { My PO encourages me to do things to improve my } \\
\text { life. }\end{array}$ & 32 & 0.79 & .000 \\
\hline $\begin{array}{l}\text { My PO gives me the opportunity to participate in } \\
\text { decisions about my supervision. }\end{array}$ & 32 & 0.76 & .000 \\
\hline $\begin{array}{l}\text { My PO encourages me to participate in programs or } \\
\text { seek assistance for whatever needs I may have (for } \\
\text { example, drug/alcohol problems, employment needs, } \\
\text { etc.). }\end{array}$ & 32 & 0.59 & .000 \\
\hline $\begin{array}{l}\text { My PO gives me the opportunity to choose programs } \\
\text { or services available to help me during my } \\
\text { supervision. }\end{array}$ & 32 & 0.61 & .000 \\
\hline $\begin{array}{l}\text { My PO helps me to prepare for tasks and decisions I } \\
\text { may face in the future. }\end{array}$ & 32 & 0.75 & .000 \\
\hline My PO treats me with respect. & 32 & 0.81 & .000 \\
\hline $\begin{array}{l}\text { My PO respects my culture and my spiritual beliefs } \\
\text { and practices. }\end{array}$ & 32 & 0.77 & .000 \\
\hline $\begin{array}{l}\text { My PO works with other groups and agencies in the } \\
\text { community to help me during my time under } \\
\text { supervision in the community. }\end{array}$ & 32 & 0.51 & .003 \\
\hline
\end{tabular}


My PO treats me fairly.

My PO listens to what I have to say and respects my

My PO helps me deal with problems or situations that 32 come up during my supervision.

My PO gives me useful advice.

My PO supports me and encourages me. agencies and groups (for example, employment agencies, government assistance, etc.).

My PO emphasizes the importance of programs and 32 services available in the community.

My PO has referred me to community groups/services 32 that may help me.

My PO talks a lot about my problems/weaknesses and 32 things I need to avoid (reverse-coded).

My PO makes plans for my time under supervision all 32 on his own, without me (reverse-coded).

I bet my PO does not think community groups and programs are helpful (reverse-coded).

My PO expects me to follow rules that don't make 32 0.58 .001 sense to me and doesn't explain them (reverse-coded).

My PO has very strict expectations and harsh penalties 
Table K2. Item-total correlations for CCPQ for male parolees.

\begin{tabular}{|c|c|c|c|}
\hline Scale item & $n$ & $r$ & $p$ \\
\hline $\begin{array}{l}\text { My PO considers my strengths when making plans for } \\
\text { my time in the community. }\end{array}$ & 24 & 0.74 & .000 \\
\hline My PO helps me feel good about myself. & 24 & 0.84 & .000 \\
\hline $\begin{array}{l}\text { My PO helps me feel like I can control my life in a } \\
\text { positive way. }\end{array}$ & 24 & 0.85 & .000 \\
\hline $\begin{array}{l}\text { My PO encourages me to find groups and services in } \\
\text { the community that can help me once my supervision } \\
\text { has ended. }\end{array}$ & 24 & 0.36 & .088 \\
\hline $\begin{array}{l}\text { My PO encourages me to do things to improve my } \\
\text { life. }\end{array}$ & 24 & 0.78 & .000 \\
\hline $\begin{array}{l}\text { My PO gives me the opportunity to participate in } \\
\text { decisions about my supervision. }\end{array}$ & 24 & 0.70 & .000 \\
\hline $\begin{array}{l}\text { My PO encourages me to participate in programs or } \\
\text { seek assistance for whatever needs I may have (for } \\
\text { example, drug/alcohol problems, employment needs, } \\
\text { etc.). }\end{array}$ & 24 & 0.54 & .006 \\
\hline $\begin{array}{l}\text { My PO gives me the opportunity to choose programs } \\
\text { or services available to help me during my } \\
\text { supervision. }\end{array}$ & 24 & 0.57 & .004 \\
\hline $\begin{array}{l}\text { My PO helps me to prepare for tasks and decisions I } \\
\text { may face in the future. }\end{array}$ & 24 & 0.72 & .000 \\
\hline My PO treats me with respect. & 24 & 0.86 & .000 \\
\hline $\begin{array}{l}\text { My PO respects my culture and my spiritual beliefs } \\
\text { and practices. }\end{array}$ & 24 & 0.77 & .000 \\
\hline $\begin{array}{l}\text { My PO works with other groups and agencies in the } \\
\text { community to help me during my time under } \\
\text { supervision in the community. }\end{array}$ & 24 & 0.47 & .021 \\
\hline
\end{tabular}


My PO treats me fairly.

My PO listens to what I have to say and respects my opinions.

My PO helps me deal with problems or situations that come up during my supervision.

My PO gives me useful advice.

My PO supports me and encourages me.

I bet my PO does not think community groups and programs are helpful (reverse-coded).

My PO expects me to follow rules that don't make 
Table K3. Item-total correlations for CCPQ for female parolees.

\begin{tabular}{|c|c|c|c|}
\hline Scale item & $n$ & $r$ & $p$ \\
\hline $\begin{array}{l}\text { My PO considers my strengths when making plans for } \\
\text { my time in the community. }\end{array}$ & 8 & 0.90 & .003 \\
\hline My PO helps me feel good about myself. & 8 & 0.93 & .001 \\
\hline $\begin{array}{l}\text { My PO helps me feel like I can control my life in a } \\
\text { positive way. }\end{array}$ & 8 & 0.96 & .000 \\
\hline $\begin{array}{l}\text { My PO encourages me to find groups and services in } \\
\text { the community that can help me once my supervision } \\
\text { has ended. }\end{array}$ & 8 & 0.60 & .120 \\
\hline $\begin{array}{l}\text { My PO encourages me to do things to improve my } \\
\text { life. }\end{array}$ & 8 & 0.88 & .004 \\
\hline $\begin{array}{l}\text { My PO gives me the opportunity to participate in } \\
\text { decisions about my supervision. }\end{array}$ & 8 & 0.94 & .001 \\
\hline $\begin{array}{l}\text { My PO encourages me to participate in programs or } \\
\text { seek assistance for whatever needs I may have (for } \\
\text { example, drug/alcohol problems, employment needs, } \\
\text { etc.). }\end{array}$ & 8 & 0.82 & .014 \\
\hline $\begin{array}{l}\text { My PO gives me the opportunity to choose programs } \\
\text { or services available to help me during my } \\
\text { supervision. }\end{array}$ & 8 & 0.76 & .029 \\
\hline $\begin{array}{l}\text { My PO helps me to prepare for tasks and decisions I } \\
\text { may face in the future. }\end{array}$ & 8 & 0.90 & .003 \\
\hline My PO treats me with respect. & 8 & 0.61 & .111 \\
\hline $\begin{array}{l}\text { My } P O \text { respects my culture and my spiritual beliefs } \\
\text { and practices. }\end{array}$ & 8 & 0.88 & .004 \\
\hline $\begin{array}{l}\text { My PO works with other groups and agencies in the } \\
\text { community to help me during my time under } \\
\text { supervision in the community. }\end{array}$ & 8 & 0.66 & .075 \\
\hline
\end{tabular}


My PO treats me fairly.

My PO listens to what I have to say and respects my opinions.

My PO helps me deal with problems or situations that $\quad 8$ come up during my supervision.

My PO gives me useful advice.

My PO supports me and encourages me.

My PO promotes my interests when dealing with other 8 agencies and groups (for example, employment agencies, government assistance, etc.).

My PO emphasizes the importance of programs and $\quad 8$ services available in the community.

My PO has referred me to community groups/services $\quad 8$ that may help me.

My PO talks a lot about my problems/weaknesses and 8 things I need to avoid (reverse-coded).

My PO makes plans for my time under supervision all $\quad 8$ on his own, without me (reverse-coded).

I bet my PO does not think community groups and programs are helpful (reverse-coded).

My PO expects me to follow rules that don't make 8 sense to me and doesn't explain them (reverse-coded).

My PO has very strict expectations and harsh penalties 8 if these expectations are not met, regardless of why they were not met (reverse-coded). 
Table K4. Item-total correlations for CCPQ for parole officer interactions with male parolees.

\begin{tabular}{|c|c|c|c|}
\hline Scale item & $n$ & $r$ & $p$ \\
\hline $\begin{array}{l}\text { I consider my clients' strengths when making plans for } \\
\text { their time in the community. }\end{array}$ & 9 & 0.51 & .164 \\
\hline I help my clients feel good about themselves. & 9 & 0.61 & .079 \\
\hline $\begin{array}{l}\text { I help my clients to feel they are in control of their } \\
\text { lives in a positive way. }\end{array}$ & 9 & 0.86 & .003 \\
\hline $\begin{array}{l}\text { I encourage my clients to find groups and services in } \\
\text { the community that can help them once their } \\
\text { supervision has ended. }\end{array}$ & 9 & 0.64 & .066 \\
\hline $\begin{array}{l}\text { I encourage my clients to take steps to improve their } \\
\text { lives. }\end{array}$ & 9 & 0.79 & .011 \\
\hline $\begin{array}{l}\text { I give my clients the opportunity to participate in } \\
\text { decisions about their supervision. }\end{array}$ & 9 & 0.66 & .052 \\
\hline $\begin{array}{l}\text { I encourage my clients to participate in programs or } \\
\text { seek assistance for whatever needs they may have (for } \\
\text { example, drug/alcohol problems, employment needs, } \\
\text { etc.). }\end{array}$ & 9 & 0.18 & .645 \\
\hline $\begin{array}{l}\text { I give my clients the opportunity to choose programs } \\
\text { or services available to help them during their } \\
\text { supervision. }\end{array}$ & 9 & 0.66 & .055 \\
\hline $\begin{array}{l}\text { I help my clients prepare for tasks and decisions that } \\
\text { they may face in the future. }\end{array}$ & 9 & 0.73 & .024 \\
\hline I treat my clients with respect. & 9 & 0.49 & .179 \\
\hline $\begin{array}{l}\text { I respect my clients' cultures and spiritual beliefs and } \\
\text { practices. }\end{array}$ & 9 & 0.68 & .046 \\
\hline $\begin{array}{l}\text { I build partnerships with other groups and agencies in } \\
\text { the community to help with the reintegration of my } \\
\text { clients. }\end{array}$ & 9 & 0.38 & .321 \\
\hline
\end{tabular}


I treat my clients fairly.

9

0.69

.039

I listen to what my clients have to say and respect their 9

0.80

.010 opinions.

I help my clients deal with problems or situations that $9 \quad 0.65$ arise during their supervision.

I give my clients useful advice.

I support my clients and encourage them.

I promote my clients' interests when dealing with other agencies and groups (for example, employment agencies, government assistance, etc.).

I emphasize to my clients the importance of programs

9

0.47 and services available in the community.

I refer my clients to community groups/services that 9 may benefit them.

I talk a lot with my clients about their problems/weaknesses and things they need to avoid (reverse-coded).

I make plans for my clients' time under supervision on 9 my own, without their input (reverse-coded).

I don't think community groups and programs help 9 my caseload (reverse-coded).

I expect my clients to follow the rules; whether they

9

0.06 understand them is not my concern (reverse-coded).

I have strict expectations for my clients and apply consequences if they are not met, regardless of the reason (reverse-coded). 
Table K5. Item-total correlations for CCPQ for parole officer interactions with female parolees.

\begin{tabular}{|c|c|c|c|}
\hline Scale item & $n$ & $r$ & $p$ \\
\hline $\begin{array}{l}\text { I consider my clients' strengths when making plans for } \\
\text { their time in the community. }\end{array}$ & 10 & 0.51 & .134 \\
\hline I help my clients feel good about themselves. & 10 & 0.75 & .013 \\
\hline $\begin{array}{l}\text { I help my clients to feel they are in control of their } \\
\text { lives in a positive way. }\end{array}$ & 10 & 0.86 & .001 \\
\hline $\begin{array}{l}\text { I encourage my clients to find groups and services in } \\
\text { the community that can help them once their } \\
\text { supervision has ended. }\end{array}$ & 10 & 0.55 & 101 \\
\hline $\begin{array}{l}\text { I encourage my clients to take steps to improve their } \\
\text { lives. }\end{array}$ & 10 & 0.75 & .013 \\
\hline $\begin{array}{l}\text { I give my clients the opportunity to participate in } \\
\text { decisions about their supervision. }\end{array}$ & 10 & 0.67 & .034 \\
\hline $\begin{array}{l}\text { I encourage my clients to participate in programs or } \\
\text { seek assistance for whatever needs they may have (for } \\
\text { example, drug/alcohol problems, employment needs, } \\
\text { etc.). }\end{array}$ & 10 & 0.23 & .519 \\
\hline $\begin{array}{l}\text { I give my clients the opportunity to choose programs } \\
\text { or services available to help them during their } \\
\text { supervision. }\end{array}$ & 10 & 0.51 & .135 \\
\hline $\begin{array}{l}\text { I help my clients prepare for tasks and decisions that } \\
\text { they may face in the future. }\end{array}$ & 10 & 0.54 & .106. \\
\hline I treat my clients with respect. & 10 & 0.54 & .109 \\
\hline $\begin{array}{l}\text { I respect my clients' cultures and spiritual beliefs and } \\
\text { practices. }\end{array}$ & 10 & 0.71 & .022 \\
\hline $\begin{array}{l}\text { I build partnerships with other groups and agencies in } \\
\text { the community to help with the reintegration of my } \\
\text { clients. }\end{array}$ & 10 & 0.40 & .248 \\
\hline
\end{tabular}


I treat my clients fairly.

10

0.71

.021

I listen to what my clients have to say and respect their 10

0.69

.028 opinions.

I help my clients deal with problems or situations that 10

0.63

.051

arise during their supervision.

I give my clients useful advice.

10

0.48

.164

I support my clients and encourage them.

10

0.64

.047

I promote my clients' interests when dealing with

10

$-0.16$

.654

other agencies and groups (for example, employment

agencies, government assistance, etc.).

I emphasize to my clients the importance of programs

10

0.46

.180

and services available in the community.

I refer my clients to community groups/services that

10

0.48

.160 may benefit them.

I talk a lot with my clients about their

10

0.10

problems/weaknesses and things they need to avoid (reverse-coded).

I make plans for my clients' time under supervision on 10 my own, without their input (reverse-coded).

I don't think community groups and programs help

10

0.59

.074 my caseload (reverse-coded).

I expect my clients to follow the rules; whether they 10

0.18 .626 understand them is not my concern (reverse-coded).

I have strict expectations for my clients and apply consequences if they are not met, regardless of the reason (reverse-coded). 
Appendix L: RSE Psychometrics 
Table Ll. Item-total correlations for RSE for parolees.

\begin{tabular}{|c|c|c|c|}
\hline Scale item & $n$ & $r$ & $p$ \\
\hline On the whole, I am satisfied with myself. & 35 & 0.82 & .000 \\
\hline I feel that I have a number of good qualities. & 35 & 0.83 & .000 \\
\hline I am able to do things as well as most other people. & 35 & 0.72 & .000 \\
\hline $\begin{array}{l}\text { I feel that I'm a person of worth, or at least on an } \\
\text { equal plane with others. }\end{array}$ & 35 & 0.87 & .000 \\
\hline I take a positive attitude toward myself. & 35 & 0.84 & .000 \\
\hline At times I think I am no good at all (reverse-coded). & 35 & 0.72 & .000 \\
\hline $\begin{array}{l}\text { I feel I do not have much to be proud of (reverse- } \\
\text { coded). }\end{array}$ & 35 & 0.85 & .000 \\
\hline I certainly feel useless at times (reverse-coded). & 35 & 0.79 & .000 \\
\hline $\begin{array}{l}\text { I wish I could have more respect for myself (reverse- } \\
\text { coded). }\end{array}$ & 35 & 0.61 & .000 \\
\hline $\begin{array}{l}\text { All in all, I am inclined to feel that I am a failure } \\
\text { (reverse-coded). }\end{array}$ & 35 & 0.73 & .000 \\
\hline
\end{tabular}


Table L2. Item-total correlations for RSE for male parolees.

\begin{tabular}{|c|c|c|c|}
\hline Scale item & $n$ & $r$ & $p$ \\
\hline On the whole, I am satisfied with myself. & 26 & 0.64 & .000 \\
\hline I feel that I have a number of good qualities. & 26 & 0.82 & .000 \\
\hline I am able to do things as well as most other people. & 26 & 0.64 & .000 \\
\hline $\begin{array}{l}\text { I feel that I'm a person of worth, or at least on an } \\
\text { equal plane with others. }\end{array}$ & 26 & 0.85 & .000 \\
\hline I take a positive attitude toward myself. & 26 & 0.83 & .000 \\
\hline At times I think I am no good at all (reverse-coded). & 26 & 0.56 & .003 \\
\hline $\begin{array}{l}\text { I feel I do not have much to be proud of (reverse- } \\
\text { coded). }\end{array}$ & 26 & 0.82 & .000 \\
\hline I certainly feel useless at times (reverse-coded). & 26 & 0.72 & .000 \\
\hline $\begin{array}{l}\text { I wish I could have more respect for myself (reverse- } \\
\text { coded). }\end{array}$ & 26 & 0.53 & .005 \\
\hline $\begin{array}{l}\text { All in all, I am inclined to feel that I am a failure } \\
\text { (reverse-coded). }\end{array}$ & 26 & 0.68 & .000 \\
\hline
\end{tabular}


Table L3. Item-total correlations for RSE for female parolees.

\begin{tabular}{|c|c|c|c|}
\hline Scale item & $n$ & $r$ & $p$ \\
\hline On the whole, I am satisfied with myself. & 9 & 0.97 & .000 \\
\hline I feel that I have a number of good qualities. & 9 & 0.87 & .002 \\
\hline I am able to do things as well as most other people. & 9 & 0.86 & .003 \\
\hline $\begin{array}{l}\text { I feel that I'm a person of worth, or at least on an } \\
\text { equal plane with others. }\end{array}$ & 9 & 0.92 & .001 \\
\hline I take a positive attitude toward myself. & 9 & 0.92 & .001 \\
\hline At times I think I am no good at all (reverse-coded). & 9 & 0.91 & .001 \\
\hline $\begin{array}{l}\text { I feel I do not have much to be proud of (reverse- } \\
\text { coded). }\end{array}$ & 9 & 0.95 & .000 \\
\hline I certainly feel useless at times (reverse-coded). & 9 & 0.83 & .005 \\
\hline $\begin{array}{l}\text { I wish I could have more respect for myself (reverse- } \\
\text { coded). }\end{array}$ & 9 & 0.68 & .045 \\
\hline $\begin{array}{l}\text { All in all, I am inclined to feel that I am a failure } \\
\text { (reverse-coded). }\end{array}$ & 9 & 0.75 & .020 \\
\hline
\end{tabular}


Community Corrections 159

Appendix M: DMQ Subscale Psychometrics 
Table M1. Item-total correlations for Social subscale for parolees.

\begin{tabular}{llll}
\hline Scale item & $n$ & $r$ & $p$ \\
\hline As a way to celebrate & 32 & 0.86 & .000 \\
$\begin{array}{l}\text { Because it is what most of your friends do when you } \\
\text { get together }\end{array}$ & 32 & 0.81 & .000 \\
$\begin{array}{l}\text { To be sociable } \\
\text { Because it is customary on special occasions }\end{array}$ & 32 & 0.81 & .000 \\
$\begin{array}{l}\text { Because it makes a social gathering more enjoyable } \\
\text { n }\end{array}$ & 32 & 0.87 & .000 \\
\hline
\end{tabular}

Table M2. Item-total correlations for Social subscale for male parolees.

\begin{tabular}{llll}
\hline Scale item & $n$ & $r$ & $p$ \\
\hline As a way to celebrate & 24 & 0.81 & .000 \\
$\begin{array}{l}\text { Because it is what most of your friends do when you } \\
\text { get together }\end{array}$ & 24 & 0.73 & .000 \\
$\begin{array}{l}\text { To be sociable } \\
\text { Because it is customary on special occasions }\end{array}$ & 24 & 0.77 & .000 \\
Because it makes a social gathering more enjoyable & 24 & 0.83 & .000 \\
\end{tabular}


Table M3. Item-total correlations for Social subscale for female parolees.

\begin{tabular}{lccc}
\hline Scale item & $n$ & $r$ & $p$ \\
\hline As a way to celebrate & 8 & 0.96 & .000 \\
$\begin{array}{l}\text { Because it is what most of your friends do when you } \\
\text { get together }\end{array}$ & 8 & 0.96 & .000 \\
$\begin{array}{l}\text { To be sociable } \\
\text { Because it is customary on special occasions }\end{array}$ & 8 & 0.95 & .000 \\
$\begin{array}{l}\text { Because it makes a social gathering more enjoyable } \\
\text { P. }\end{array}$ & 8 & 0.94 & .000 \\
\end{tabular}

Table M4. Item-total correlations for Coping subscale for parolees.

\begin{tabular}{lccc}
\hline Scale item & $n$ & $r$ & $p$ \\
\hline To relax & 32 & 0.76 & .000 \\
$\begin{array}{l}\text { To forget your worries } \\
\text { Because you feel more self-confident or sure of }\end{array}$ & 32 & 0.87 & .000 \\
$\begin{array}{l}\text { yourself } \\
\begin{array}{l}\text { Because it helps you when you feel depressed or } \\
\text { nervous }\end{array}\end{array}$ & 32 & 0.92 & .000 \\
$\begin{array}{l}\text { To cheer up when you're in a bad mood } \\
\text { nat }\end{array}$ & 32 & 0.87 & .000 \\
\hline
\end{tabular}


Table M5. Item-total correlations for Coping subscale for male parolees.

\begin{tabular}{lccc}
\hline Scale item & $n$ & $r$ & $p$ \\
\hline To relax & 24 & 0.69 & .000 \\
$\begin{array}{l}\text { To forget your worries } \\
\text { Because you feel more self-confident or sure of } \\
\text { yourself }\end{array}$ & 24 & 0.86 & .000 \\
$\begin{array}{l}\text { Because it helps you when you feel depressed or } \\
\text { nervous }\end{array}$ & 24 & 0.89 & .000 \\
$\begin{array}{l}\text { To cheer up when you're in a bad mood } \\
\text { n }\end{array}$ & 24 & 0.85 & .000 \\
\hline
\end{tabular}

Table M6. Item-total correlations for Coping subscale for female parolees.

\begin{tabular}{lccc}
\hline Scale item & $n$ & $r$ & $p$ \\
\hline To relax & 8 & 0.96 & .000 \\
To forget your worries & 8 & 0.89 & .004 \\
$\begin{array}{l}\text { Because you feel more self-confident or sure of } \\
\text { yourself }\end{array}$ & 8 & 0.98 & .000 \\
$\begin{array}{l}\text { Because it helps you when you feel depressed or } \\
\text { nervous }\end{array}$ & 8 & 0.98 & .000 \\
$\begin{array}{l}\text { To cheer up when you're in a bad mood } \\
\text { n }\end{array}$ & 8 & 0.92 & .001
\end{tabular}


Table M7. Item-total correlations for Enhancement subscale for parolees.

\begin{tabular}{llll}
\hline Scale item & $n$ & $r$ & $p$ \\
\hline Because you like the feeling & 32 & 0.87 & .000 \\
Because it's exciting & 32 & 0.86 & .000 \\
To get high & 32 & 0.72 & .000 \\
Because it's fun & 32 & 0.84 & .000 \\
Because it makes you feel good & 32 & 0.84 & .000 \\
\hline
\end{tabular}

Table M8. Item-total correlations for Enhancement subscale for male parolees.

\begin{tabular}{llll}
\hline Scale item & $n$ & $r$ & $p$ \\
\hline Because you like the feeling & 24 & 0.90 & .000 \\
Because it's exciting & 24 & 0.85 & .000 \\
To get high & 24 & 0.78 & .000 \\
Because it's fun & 24 & 0.82 & .000 \\
Because it makes you feel good & 24 & 0.86 & .000 \\
\hline
\end{tabular}


Table M9. Item-total correlations for Enhancement subscale for female parolees.

\begin{tabular}{lccc}
\hline Scale item & $n$ & $r$ & $p$ \\
\hline Because you like the feeling & 8 & 0.94 & .001 \\
Because it's exciting & 8 & 0.93 & .001 \\
To get high & 8 & 0.54 & .163 \\
Because it's fun & 8 & 0.91 & .002 \\
Because it makes you feel good & 8 & 0.81 & .015 \\
\hline
\end{tabular}

